\title{
A Study of Earthquakes in Relation to Volcanic Activity (III)
}

-Earthquakes during the period of activity of Volcano Usu (1943-1945), two new phases of the earthquakes, and earthquakes of crypto-volcanic activity at Itô-

By

\author{
Takashi Kizawa \\ Meteorological Research Institute, Tokyo
}

(Received April 30, 1960)

\begin{abstract}
The writer made a consecutive study of the earthquake swarms which occurred accompanied by the volcanic activity of Volcano Usu, Hokkaido, from December 1943 to October 1945. The famous Showa Shinzan was born in the course of this activity. As a sequel to the first and second papers, the writer prepared this third paper in which the following problems are discussed.
\end{abstract}

1). As a result of the study of the earthquakes (A-type earthquakes) that occurred prior to eruptions, the writer obtained the value of the distance coefficient, $\mathrm{k}=8.2 \mathrm{~km} / \mathrm{sec}$, near Showa Shinzan. At the same time the depth of the hypocenter was determined to be about $10 \mathrm{~km}$. By using $\mathrm{k}=8.2 \mathrm{~km} / \mathrm{sec}$, the distribution of the epicenters of A-type earthquakes was studied.

2). From the decay formula of the maximum amplitude for surface waves

$$
A=A_{0} \Delta^{-1 / 2} e^{-\alpha \Delta},
$$

the value $a$ was obtained as follows:

$$
\begin{aligned}
& \alpha=5.8 \times 10^{-3} \mathrm{~km}^{-1}(25<\Delta<700 \mathrm{~km}), \\
& \alpha=5.6 \times 10^{-3} \mathrm{~km}^{-1}(25<\Delta<800 \mathrm{~km}) .
\end{aligned}
$$

By the following formulas the decay of frequency $N$ and ground amplitude $A$ with the lapse of time were studied.

$$
\begin{aligned}
& N(t)=K(t+C)^{-p}, \\
& A(t)=K^{\prime}\left(t+C^{\prime}\right)^{-p^{\prime}},
\end{aligned}
$$

where $K, K^{\prime}, C, C^{\prime}, p$ and $p^{\prime}$ are constants. These constants were obtained from the data of the A-type earthquakes observed at Muroran, Mori and Sapporo.

3). In the waves of all earthquakes of A-type recorded by the seismograph at Mori Observatory (Mori Weather Station), S'-waves, reflected S-waves, were found several seconds after S-waves, and the depth of the Moho discontinuity was calculated as $H=25.0 \mathrm{~km}$ (mean value).

4). Energy of earthquakes and energy of ground upheaval were cal- 
culated, and their relation to the number of earthquakes and to other phenomena were considered.

5). In the seismograms at Mori Observatory two new phases were discovered. These were tentatively named the third phase and the fourth phase. Most of the path of the seismic waves are in shallow sea water. The waves were treated as Rayleigh waves, and various conditions were given to the crustal structure of "liquid-liquid-solid" layers or "liquidsolid-solid" layers. The dispersion curves of Rayleigh waves for every case were computed by IBM 704 electronic computer. The sedimentary layer, or the second layer, was assumed to be solid, and importance was attached to this layer. By assuming a condition such that the velocity of the compressional wave is smaller than that of the first layer, and by adjusting the ratio of the thickness, a result was obtained, by which the above-mentioned 3rd and 4th phases might be most satisfactorily explained.

Thus an important hint was obtained, in regard to the nature and effect of the sedimentary layer.

6). The values of $m$ in the Ishimoto-Iida's formula, $n d A=K A^{-m} d A$, are calculated by the use of data of the Ito crypto-volcanic activity and the Kita-Izu earthquake swarms in 1930.

By means of cumulative frequency calculation, mean values for the above two groups were respectively given, as $m=1.85$ and $m=1.50$. These values were compared with those obtained from the forerunning earthquakes of Usu volcanic eruption.

\section{Introduction}

The activity of Volcano Usu is usualiy accompanied by marked earthquake swarms (IsHikAWA, 1950; MinakAmi and others, 1951; KizAWA, 1957, 1959). The earthquakes, that occurred during the volcanic activity from 1943 to 1945 and formed Showa Shinzan, were especially striking. Some of them were recorded by the Wiechert seismograph installed at an $800 \mathrm{~km}$ distance from the epicenter.

With an aim to clarify the nature of these earthquakes, the writer has been studying the seismograms of Muroran $(\Delta=25 \mathrm{~km})$, Mori $(\Delta=54 \mathrm{~km})$ and Sapporo $(\Delta=69 \mathrm{~km})$ Observatories around the Volcano Usu, and other seismologic data obtained through the observation network of the Japan Meteorological Agency. Main results of the study have been reported (T. KIZAWA, 1957, 1959 and 1960).

The present paper summarizes the results of later research on some of these observation records. It comprises the following section; 2). Nature of pre-eruption earthquakes; 3). Relationships between maximum amplitude and epicentral distance; 4). Underground discontinuity between Volcano Usu and Mori; 5). Earthquakes and ground upheaval accompanying the birth of Showa Shinzan; 6). Two new phases discovered in the earthquakes of the Usu-Mori path; 7). Nature of submarine earthquakes of crypto-volcanic activity off Itô and the Kita-Izu earthquake swarms.

The writer intends to study the volcanic earthquakes of Sakurajima, Kyushu, as a part of his continuous research on the relationships between volcanic activity and associated earthquakes. 


\section{Nature of pre-eruption earthquakes}

\section{Hypocenter and distance coefficient}

When $x, y$ and 0 are the co-ordinates of a observatory, $x_{0}, y_{0}$ and $h$ those coordinates of the hypocenter of the earthquake which occurred at the depth of $h$, and $t$ the duration from $P$ to $S$, then the relation formula is as follows:

$$
\left(x-x_{0}\right)^{2}+\left(y-y_{0}\right)^{2}+h^{2}=k^{2} t^{2} .
$$

As the equation contains four unknown quantities, inclusive of the distance coefficient $k$, the observation data of at least four stations are needed for determination of the hypocenter.

In general the hypocenter of forerunning earthquakes (A-type earthquakes) cannot be determined, because observations of such earthquakes are made only at three observatories, Muroran, Mori and Sapporo. Nevertheless, judging from the various phenomena observed on the ground surface (T. IsHikAWA, 1950, T. Minakami and others, 1951), the epicenter of A-type earthquakes is thought to lie at the foot of Volcano Usu. Presuming the epicenter of the A-type earthquakes so, the writer calculated the value of the distance coefficient $k$. For this calculation, observation data at two stations may be sufficient. When the S-wave in the seismograms at Sapporo was obscure, a combination of Muroran and Mori seismograms was used.

The values of the distance coefficient obtained by analysing the seven A-type earthquakes which were accurately recorded are shown in Table 1 . On the basis of the distance coefficient $k$ near Showa Shinzan, the mean value of them is 8.2. At the same time the depth of the hypocenter is determined to be about $10 \mathrm{~km}$ (mean value) as seen in Fig. 1.

Kenzô Sassa (1936) used $4.5 \mathrm{~km} / \mathrm{sec}$ as the distance coefficient at Volcano Aso. R. TAKAHAsi and T. NAgAta (1939) studied earthquakes at Osima, and obtained the distance coefficient as $k=2.2+0.41 \mathrm{z}$ for the earthquakes originating from near the earth's surface and $1 \mathrm{~km}$ below it. Around the Volcano Usu the distance coefficients were assumed to be 2.0 and $2.3 \sim 5.2 \mathrm{~km} / \mathrm{sec}$ for the earthquakes near the earth's

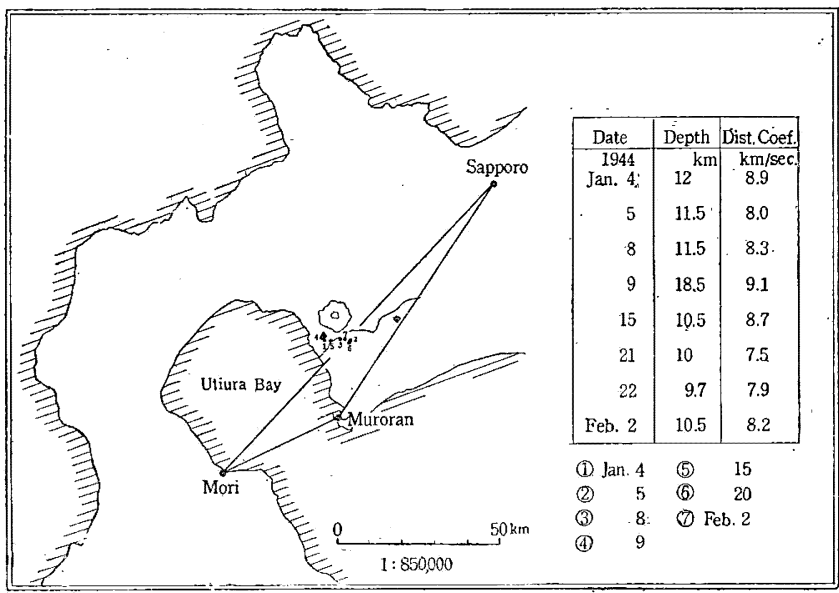

Fig. 1. Distribution of epicenters of some A-type earthquakes occurred during one month from Jan. 4, 1944. Seismological observatories are Muroran, Mori and Sapporo. The table in Fig. 1 shows values of depth of hypocenter $h$ and distance coefficient calculated by determining the hypocenter to be at the foot of Mt. Usu. The earthquake of Jan. 9 is different in nature from any other earthquakes, and it will be mentioned in Sections 2 and 3 . 
surface and 1 4 $\mathrm{km}$ deep by T. MinakamI, T. Ishikawa and Y. Yagi (1951). These values of $k$ are small. On the other hand Toshimatu Matumoto (1959) gave $k=8 \mathrm{~km} / \mathrm{sec}$ for Tesikaga earthquakes in Hokkaido, which corresponds with the value obtained above.

\section{Distribution of epicenters of A-type earthquakes}

Using the mean value of the distance coefficient thus obtained, the writer attempted to determine the epicenter on the basis of the three-point observations.

Table 2. Duration of $P-S$ and hypocentral distance $\triangle$.

\begin{tabular}{|c|c|c|c|c|c|c|c|}
\hline \multirow{2}{*}{\multicolumn{2}{|c|}{ Date }} & \multicolumn{3}{|c|}{ (sec.) } & \multicolumn{3}{|c|}{$\triangle(=8.2 t \mathrm{~km})$} \\
\hline & & Muroran & Mori & (Sapporo) & Muroran & Mori & (Sapporo) \\
\hline \multirow[t]{6}{*}{$\begin{array}{l}1944 \\
\text { Jan. }\end{array}$} & 4 & 3.00 & 6.25 & 8.86 & 24.6 & 51.5 & 71.0 \\
\hline & 5 & 3.25 & 7. 02 & 9.35 & 26.6 & 57.6 & 76.7 \\
\hline & 8 & 3.12 & 6.77 & 8.45 & 25.6 & 55.5 & 69.3 \\
\hline & 9 & 3.29 & 6.40 & 8.70 & 27.0 & 52.5 & 71.4 \\
\hline & 15 & 2.94 & 6.44 & - & 24.2 & 52.8 & - \\
\hline & 21 & 3.05 & 6.90 & 8.84 & 25.0 & 56.6 & 72.5 \\
\hline Feb & 2 & 3.13 & 6.84 & 8.77 & 25.7 & 56.1 & 71.9 \\
\hline
\end{tabular}

The observation points were Muroran, Mori and Sapporo. As is mentioned above, the commencement of S-wave in the Sapporo seismograms was obscure, and so the writer attached importance to the seismograms of Muroran and Mori. The distribution of epicenters of A-type earthquakes is diagrammatized in Fig. 1. Refer also to Table 2 .

Decay in frequency and amplitude of pre-eruption earthquakes by the lapse of time

Presuming that the frequency and ground double amplitude of earthquakes. diminish with time according to the formulas (Cf.: F. OOMRI 1931, S. NAKAMurA. 1954, and T. Matumoto 1959).

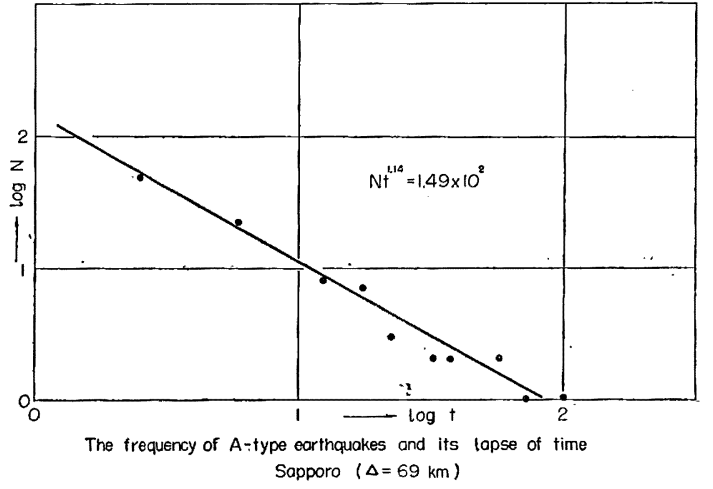

Fig. 2-a

$$
\begin{aligned}
& N(t)=K(t+C)^{-p}, \\
& A(t)=K^{\prime}\left(t+C^{\prime}\right)^{-p \prime},
\end{aligned}
$$

the constants were determined as follows : sides

By taking logarithms on two

$\log N+p \log t=\log K$,

$\log A+p^{\prime} \log t=\log K^{\prime}$,

where the values of $\log K, \log K^{\prime}$, $p$ and $p^{\prime}$ were constants obtained by the least square method. The 


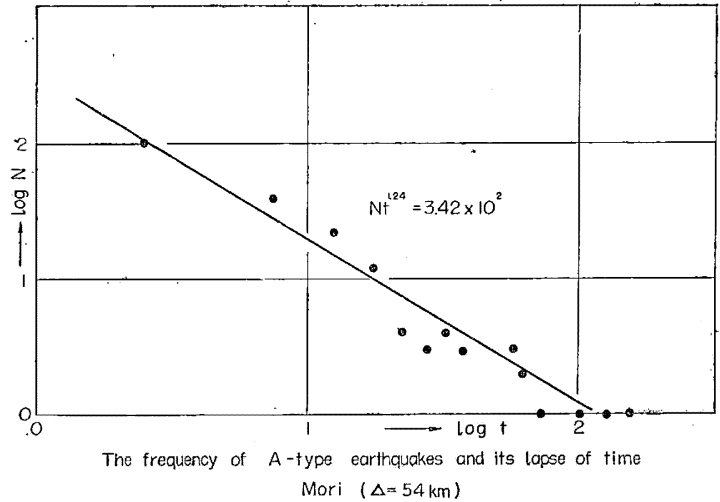

Fig. 2-b.

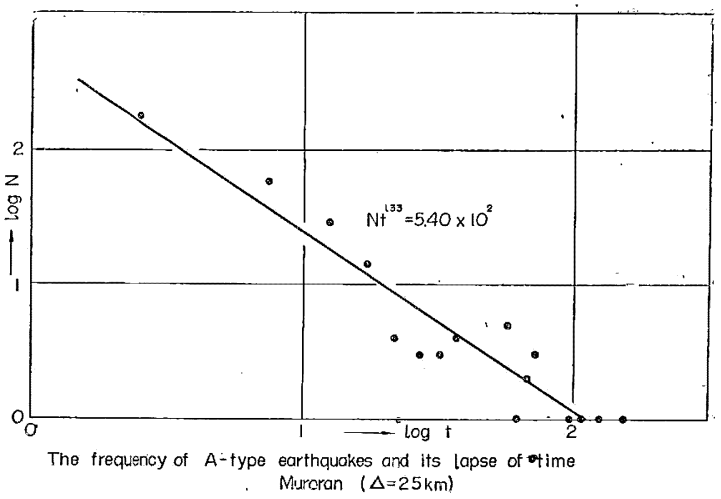

Fig. 2-c.

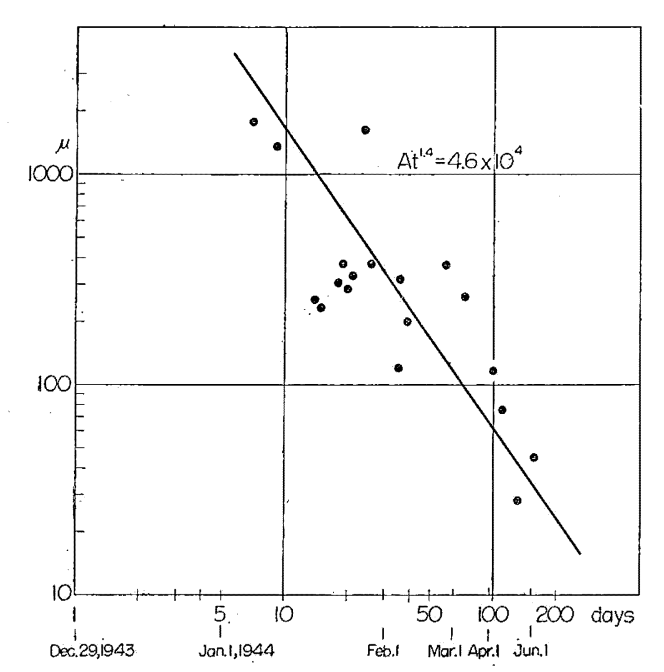

Ground Double Amplitude and the Lapse of Time for

the Forerunning A-type Earthquakes. (at Muroran) frequency data were prepared at three stations Muroran, Mori and Sapporo. And for the relationships between ground amplitude and the lapse of time, observation data of the horizontal component of ground double amplitudes of A-type earthquakes at Muroran and Mori were prepared. Here $t$ is the lapse of days from Dec. 28, 1943 when the A-type Usu volcanic earthquake swarms began.

The same samples were studied on the basis of these observation data and calculations were made independently. The results are shown in Table 3 and Figs. 2 and 3 . The values thus obtained revealed a fair coincidence.

Eruptions occurred after the A-type earthquakes had declined. Then the above-mentioned results are significant as they represent the mode of occurrence of the preeruption earthquakes.

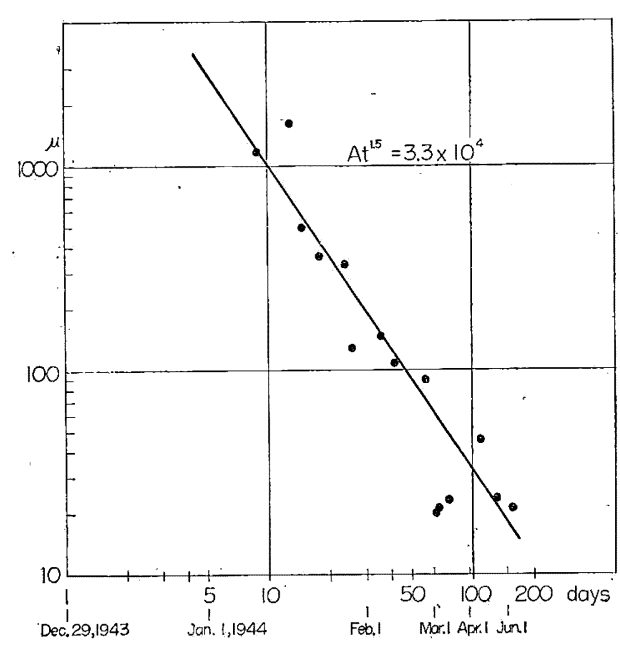

Ground Double Amplitude and the Lapse of Time for the Forerunning A-type Earthquakes. (at Mori).

Fig. 3. 
Table 3. Constants on the formula.

(a) $N(t)=K(t+c)^{-p}$

\begin{tabular}{|l|c|c|}
\hline Observatory & $p$ & $K$ \\
\hline Sapporo & 1.14 & $1.49 \times 10^{2}$ \\
Mori & 1.24 & $3.42 \prime \prime$ \\
Muroran & 1.33 & $5.40 \prime \prime$ \\
\hline
\end{tabular}

(b) $A(t)=K^{\prime}\left(t+c^{\prime}\right)^{-p^{\prime}}$

\begin{tabular}{|l|c|c|}
\hline Observatory & $p^{\prime}$ & $K^{\prime}$ \\
\hline Mori & 1.5 & $3.3 \times 10^{4}$ \\
Muroran & 1.4 & $4.6 "$ " \\
\hline
\end{tabular}

\section{Relationships between maximum amplitude and epicentral distance}

\section{On pre-eruption earthquakes}

Some of the A-type earthquakes were remarkably great. Those that occurred on the 5 th and 9 th of January 1944 were especially great, and were recorded at many observatories, the latter being detected by the Wiechert seismograph at Tomisaki located $852 \mathrm{~km}$ in epicentral distance. On the basis of these data (Table 4), the writer obtained a diminution formula of the maximum amplitude A (composite value of horizontal components).

Table 4. Maximum ground amplitude of the A-type earthquakes.

(a) Jan. 5, 1944

\begin{tabular}{|c|c|c|c|c|c|c|}
\hline Station & $\begin{array}{l}\text { epicentral dis- } \\
\text { tance }(\Delta \mathrm{km})\end{array}$ & $A_{E}(\mu)$ & $A_{N}(\mu)$ & $\begin{array}{r}A_{I I}(= \\
\left.\sqrt{A_{E^{2}}+A_{N}^{2}}\right)\end{array}$ & $\begin{array}{l}\text { ground correc- } \\
\text { tion factor }\end{array}$ & $\begin{array}{c}\text { ground } \\
\text { amplitude }(\mu)\end{array}$ \\
\hline Muroran & 25 & 680 & $S$-out & - & - & - \\
\hline Mori & 54 & 365 & 453 & 582 & 0.7 & 407 \\
\hline Sapporo & 69 & 129 & 150 & 198 & 1.1 & 218 \\
\hline Urakawa & 164 & 32.0 & 32.0 & 44.3 & 2.7 & 120 \\
\hline Asahikawa & 182 & 20.0 & 25.0 & 31.0 & 0.5 & 15.5 \\
\hline Hachinohe & 300 & 5.5 & 11.1 & 12.4 & 2. 3 & 28.5 \\
\hline Akita & 345 & 12.9 & 8.9 & 15.7 & 0.8 & 12.5 \\
\hline Miyako & 365 & 5.6 & 5.3 & 7.7 & 3.3 & 25.3 \\
\hline Sendai & 473 & 3.2 & 6.3 & 7.1 & 1.3 & 9.2 \\
\hline Fukushima & 538 & 2.8 & 3.1 & 4.1 & 1.6 & 6.6 \\
\hline Shirakawa & 630 & 2.5 & 2.5 & 3.6 & 1.5 & 5.4 \\
\hline
\end{tabular}

(b) Jan. 9, 1944

\begin{tabular}{|c|c|c|c|c|c|c|}
\hline Station & $\begin{array}{l}\text { epicentral dis- } \\
\text { tance } \Delta(\mathrm{km})\end{array}$ & $A_{E}(\mu)$ & $A_{N}(\mu)$ & $\begin{array}{r}A_{H}(= \\
\sqrt{\left.A_{E^{2}}+A_{N}{ }^{2}\right)}\end{array}$ & $\begin{array}{l}\text { ground correc- } \\
\text { tion factor }\end{array}$ & $\begin{array}{c}\text { ground } \\
\text { amplitude }(\mu)\end{array}$ \\
\hline Muroran & 25 & $S$-out & 805 & & - & - \\
\hline Mori & 54 & 470 & 651 & 804 & 0.7 & 563 \\
\hline Sapporo & 69 & 317 & 324 & 453 & 1.1 & 498 \\
\hline Urakawa & 164 & 92.0 & 99.0 & 135 & 2.7 & 365 \\
\hline Asahikawa & 182 & 30.0 & 35.0 & 45.1 & 0.5 & 22.6 \\
\hline Hachinohe & 300 & 27.7 & 10.1 & $29 . \overline{5}$ & 2.3 & 67.9 \\
\hline Morioka & 330 & 12.5 & 4. 0 & 13. 1 & 1.8 & 23.6 \\
\hline Akita & 345 & 23.5 & 11.8 & 26.3 & 0.8 & 21.0 \\
\hline Sendai & 473 & 12.7 & 6.3 & 14.2 & 1.3 & 18.5 \\
\hline Fukushima & 538 & 5.5 & 6.1 & 8.2 & 1.6 & 13.1 \\
\hline Shirakawa & 630 & 6.3 & 6.3 & $8 . \overline{9}$ & 1.5 & 13.4 \\
\hline
\end{tabular}

(for calculation of the maximum amplitude decay formula, the data at Morioka were excepted) 
Using the diminution formula of the surface wave

$$
A=A_{0} \Delta^{-1 / 2} e^{-\alpha \Delta},
$$

the results obtained for the two earthquakes of January 5 and 9,1944 are shown in Fig. 4 and Table 5.

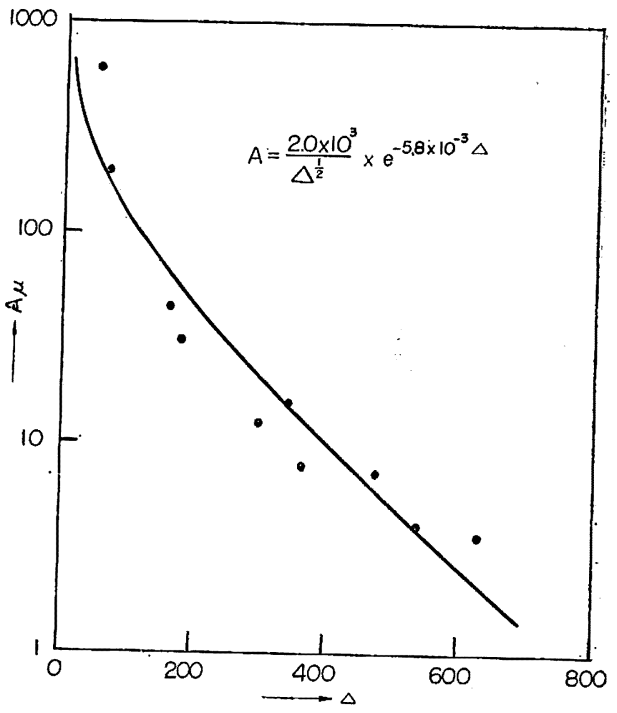

(a) Jan. 5, 1944 A-type.

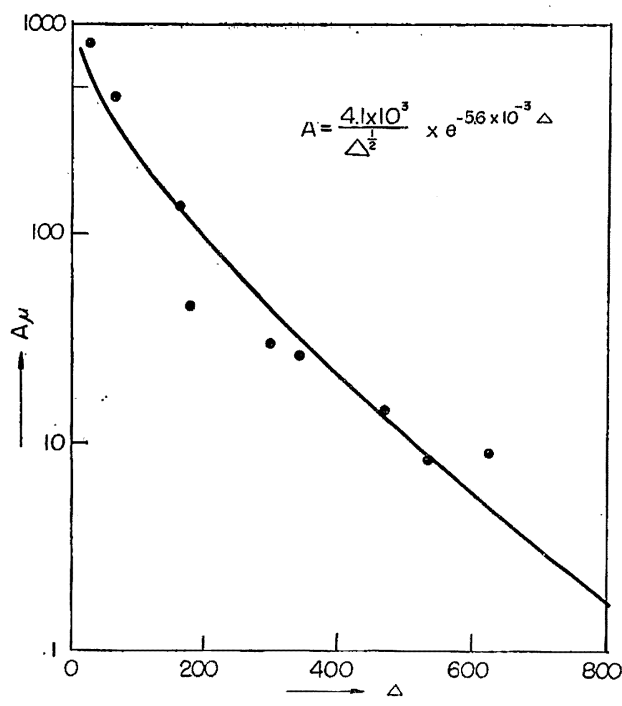

(b) Jan. 9, 1944 A-type.

Fig. 4. Maximum ground amplitude and epicentral distance.

The values of the absorption coefficient at Oshima were reported as 2.7 to $3.3 \times 10^{-1} \mathrm{~km}^{-1}$ (T. Minakami and others, 1951). B. GUTENBERG obtained the value $\alpha=0.36 \times 10^{-3} \mathrm{~km}^{-1} \quad(T=20 \mathrm{sec})$ from the surface waves that traveled through the Pacific Ocean, and the writer, by studying the observation data of the great earthquake of Chile in 1939, as recorded in various parts of Japan, obtained a mean value of $\alpha=$ $0.29 \times 10^{-3} \mathrm{~km}^{-1}$ ( $T$ being $30-45 \mathrm{sec}$ ).

Concerning the present subject, there are some other works such as those by Ewing and Press (1954), Y. Satô (1958), etc. However, these are the reports of distant observations, and only the values of earthquakes having great magnitude are mentioned. Thus, owing to different conditions, the values of the absorption coefficient in the above-mentioned reports are much smaller than those obtained by the writer during his recent research on volcanic earthquakes.

A noteworthy factor with regard to this problem is the values of $\alpha$ obtained by $\mathrm{K}$. WADATI (1931) who succeeded in drawing a reliable A- $\Delta$ curve for the first time (see Table 6). The results of K. WADATI's study on some earthquakes that 
fall within the magnitude range* of from 6.2 to 5.4 , are shown in Table 6 .

Table 6. Values of $a\left(\mathrm{~km}^{-1}\right)$ (after K. WADATI).

\begin{tabular}{|c|c|c|c|c|c|c|}
\hline size & $\begin{array}{l}\text { earth- } \\
\text { quakes }\end{array}$ & $M$ & $\Delta=200 \mathrm{~km}$ & $400 \mathrm{~km}$ & $600 \mathrm{~km}$ & $800 \mathrm{~km}$ \\
\hline large & 5 & $\begin{array}{l}6.7,6.7,6.2 \text {, } \\
6.2,5.9\end{array}$ & $7.1 \times 10^{-3}$ & 4. $6 \times 10^{-3}$ & 3. $9 \times 10^{-3}$ & 3. $4 \times 10^{-3}$ \\
\hline medium & 7 & $\begin{array}{l}6.2,6.0,5.9, \\
5.8,5.6,5.5, \\
5.4\end{array}$ & $6.5 \mathrm{\prime \prime}$ & $5.6 "$ & $5.6 \quad$ & \\
\hline small & 3 & $5.6,5.4,5.4$ & $8.5 "$ & $7.2 \quad$ & & \\
\hline
\end{tabular}

As was reported by the writer previously (Paper I), the magnitude (M) of the earthquakes associated with the recent volcanic activity of Volcano Usu was about 4.7 on January 5 , and about 4.8 on January 9 . The epicentral distance ranging from $25 \mathrm{~km}$ to $800 \mathrm{~km}$, and the period of seismic waves are similar to those which Wadati dealt with. Hence, the two cases may be compared. The result has revealed that the values of $\alpha$ were almost identical for both cases, and therefore it is presumed that the nature of the A-type volcanic earthquakes of Usu is not different from that of the tectonic earthquakes (In this case, the observation values of the maximum amplitude were used as they are, because, if the ground coefficient at each observation point is taken into account, adjustment of the values becomes difficult).

\section{Underground discontinuity around Volcano Usu and Mori}

\section{$S$ 'waves, reflected $S$ waves, observed}

The seismogram at Mori Observatory which recorded the A-type earthquakes revealed various bodily waves consecutive to the S-waves, owing to the fact that the Mori-Usu path runs through the sea and that the arrival of the surface waves was considerably delayed.

Especially conspicuous bodily waves were tentatively named S'-waves. As shown
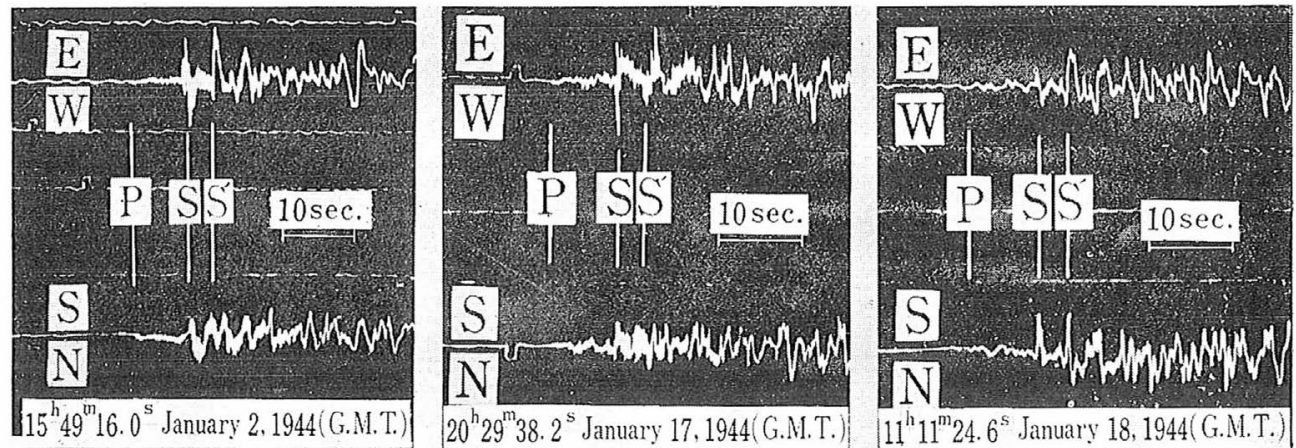

Fig. 5-a. Enlarged seismograms of Fig. 5--b. 

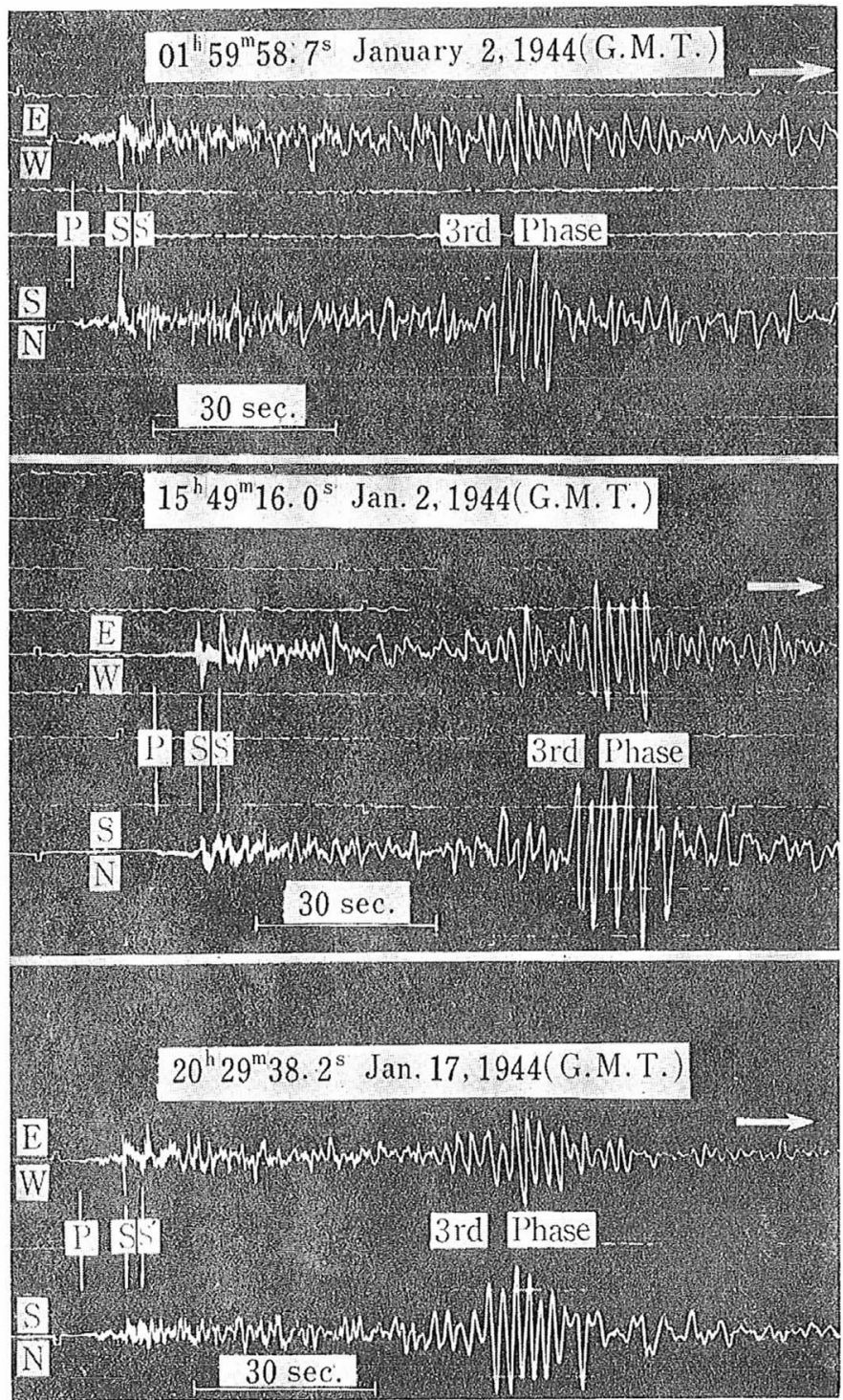

Fig. 5-b. Seismograms at Mori Observatory in Hokkaido showing the $P, S$ and $S^{\prime}$ related from the Moho.

Mori Observatory: $\quad \zeta=42^{\circ} 06^{\prime} N, \lambda=140^{\circ} 34^{\prime} E, H=18.7 \mathrm{~m}$ (a.s.1.) Mori Wiechert seismograph

Magnification: $V_{N}=86, \quad V_{E}=85$

Period: $T_{0 N}=3.9 \mathrm{sec} ., T_{v E}=4.0 \mathrm{sec}$. in the upper diagram of Fig. 5, the amplitude of the E-W component surpasses the amplitude of the N-S component. The location of Mori Observatory is $\mathrm{S} 27^{\circ} \mathrm{W}$ from the hypocenter, as was already reported in the author's previous papers (I) and (II).

Judging from the predominance of the $\mathrm{E}-\mathrm{W}$ components, these waves may have the character of SH-waves.

\section{Depth of the discon- tinuous surface}

However, the writer presumed that they are related to the discontinuity, on the basis of a model illustrated in Figs. 6-a, b and calculated the depth $\mathrm{H}$ of the surface of *discontinuity (A. MoHOROVIČIĆ, 1909). With regard to the velocity of Swaves, a large number of measurement data have been published, but the writer adopted in the present study the values by Prof. T. Matsuzawa (1929).

For the calculation the depth of the hypocenter of A-type earthquakes was determined as $10 \mathrm{~km}$, by referring to the previously obtained values (Section 1). 


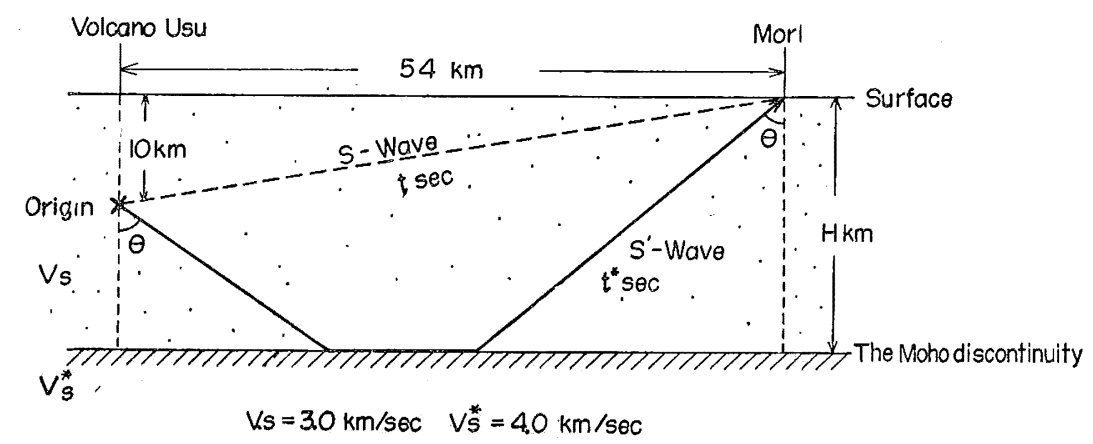

Fig. 6-a. Crustal model around Volcano Usu and the path of direct $S$-wave and refracted $S$ '-wave.

The condition for $\theta$ is, $\sin \theta=\frac{v_{s}}{v_{s}^{*}}=\frac{3}{4}$.

Thus,

$$
\begin{gathered}
t^{*}-t=\left(\frac{2 H-10}{v_{s} \cos \theta}+\frac{54-(2 H-10) \tan \theta}{v_{s}^{*}}\right)-\frac{\sqrt{54^{2}+10^{2}}}{v_{s}} \\
\therefore H=\frac{6}{\sqrt{7}}\left\{\left(t^{*}-t\right)+\frac{29+5 \sqrt{7}}{6}\right\},
\end{gathered}
$$

was obtained. The result is tabulated in Table 7 .

The mean value of the depth to the surface of discontinuity becomes

$$
H r_{(\text {mean })}=25.2 \mathrm{~km}
$$

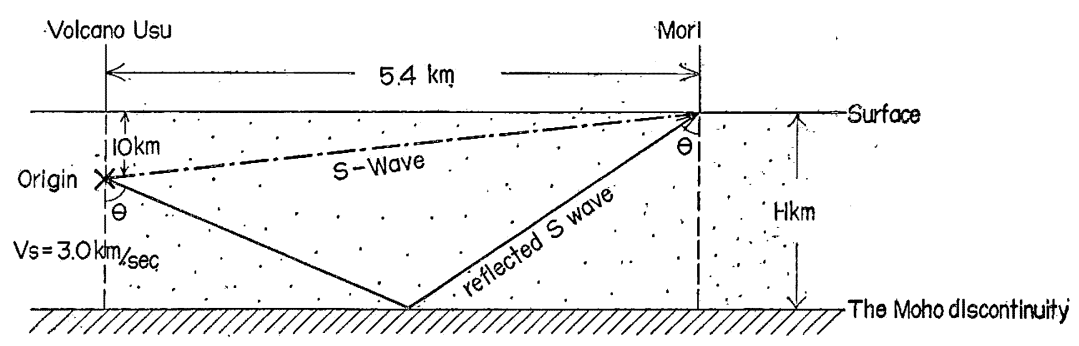

Fig. 6-b. Crustal model around Volcano Usu and the path of direct $\mathrm{S}$-wave and reflected $S^{\prime}$-wave.

On the other hand, as the amplitude of S'-waves is comparable to S-waves, S'waves are thought to be the transverse waves reflected by the base of the discontinuity (Fig. 6-b). Presuming such a case, the writer obtained the depth of the base $H_{l}$ as shown in Table 7 . And the mean value of $H_{l}$ is obtained as $H_{l(\text { mean })}=$ 
$25.0 \mathrm{~km}$, which is nearly equal to the result calculated by assuming $\mathrm{S}^{\prime}$-wave to be reflected transverse waves.

Table 7. Depth of the discontinuous layer around the Volcano Usu: $H_{l}$ : ( $S^{\prime}$ as reflected wave)

$H_{r}:\left(S^{\prime}\right.$ as refracted wave)

\begin{tabular}{|c|c|c|c|c|}
\hline \multicolumn{2}{|c|}{ Date } & $t^{*}-t$ & $H_{l}$ & $H_{r}$ \\
\hline \multicolumn{2}{|c|}{1944} & sec & $\mathrm{km}$ & $\mathrm{km}$ \\
\hline \multirow[t]{8}{*}{ Jan. } & 2 & 5.4 & 28.0 & 28.1 \\
\hline & " & 3.7 & 24.1 & 24.2 \\
\hline & $n$ & 3.8 & 24.3 & 24.5 \\
\hline & $" 1$ & 3.1 & 22.4 & 22.9 \\
\hline & 3 & 4.1 & 25.0 & 25.2 \\
\hline & $" \prime$ & 3.9 & 24.6 & 24.7 \\
\hline & 17 & 4.6 & 26.3 & 26.3 \\
\hline & 18 & 4.9 & 27.0 & 27.0 \\
\hline \multirow[t]{2}{*}{ Feb. } & 1 & 4.1 & 25.1 & 25.2 \\
\hline & 24 & 3.5 & 23.5 & 23.8 \\
\hline \multicolumn{3}{|c|}{ mean value } & 25.0 & 25.2 \\
\hline
\end{tabular}

Takeo Matsuzawa (1959), in the course of his observations of seismic explosion recognized a discontinuous layer at the depth of 20 to 25 $\mathrm{km}$ in northeastern Japan. And the depth of the discontinuity $H=22 \sim 23 \mathrm{~km}$ was obtained at Hokoda in northeastern Japan by the Explosion Group.* It is noticeable that the writer's value is approximately equal to this.

\section{For Suggestion}

In the previous case, the $S^{\prime}$-wave was treated as a refraction waves of the $S$-wave, and $V_{s}=3.0$ $\mathrm{km} / \mathrm{sec}$ and $V_{s}^{*}=4.0 \mathrm{~km} / \mathrm{sec}$ were adopted as the velocity of the transverse waves. The writer calculated for another case where $V_{s}=$ $3.58 \mathrm{~km} / \mathrm{sec}, V_{s}^{*}=4.44 \mathrm{~km} / \mathrm{sec}$. These values were applied to the Hokoda Explosion by The Research Group for Explosion Seismology (1959). The result shows that the depth of the MoHoROVIČIć discontinuity $H$ is $26.2 \mathrm{~km}$.

\section{The earthquake of January 9 seems to be related with the Mohorovičic discontinuity.}

In the earthquakes of January 9 , the depth of the hypocenter obtained from the travel-time was $H=20$ odd $\mathrm{km}$, as was shown in Fig. 8 (See T. KizAwA 1957, 1959). This fact suggests that these earthquakes were caused by the activity in the discontinuity (Moho layer) unlike other A-type earthquakes. The result of the writer's study, as was reported also in Parts I and II of this series of papers, implies that the earthquakes are related to the immigration and activity of a magma, and shows that, as time approached to the eruption, the depths of hypocenter became shallower gradually.** (See T. KIZAWA 1957, 1959). That is to say, the distribution of the initial motions of the P-waves were uniform through January and February as shown in Fig. 7, whereas the earthquakes of January 9 which probably occurred near the discontinuity showed a marked difference, for "compressional" waves and "dilatational" waves are reversely distributed, as Fig. 7-b indicates. This is a noteworthy phenomenon.

From the fact that the values of initial motions at Mori are always small, it can be assumed that a nodal line runs through the vicinity of Mori. Although the data from only three observation points are insufficient for any definite conclusion, we will notice that the nodal lines drawn on Fig. 7 adequetely coincide with the OusuKousu tectonic line and another tectonic line intersecting the former nearly at right

* The Research Group for Explosion Seismology; Observations of Seismic Waves from the Second Hokoda explosion (1959), Bull. Earthq. Res. Inst. 37, 495-508.

** cf. section 1, Fig. 1 


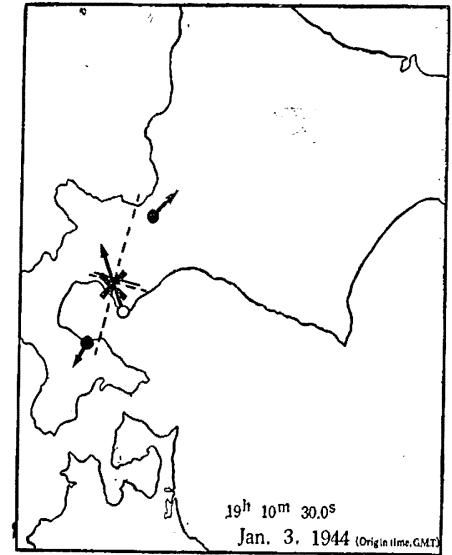

Depth of focus $H=12 \mathrm{~km}$

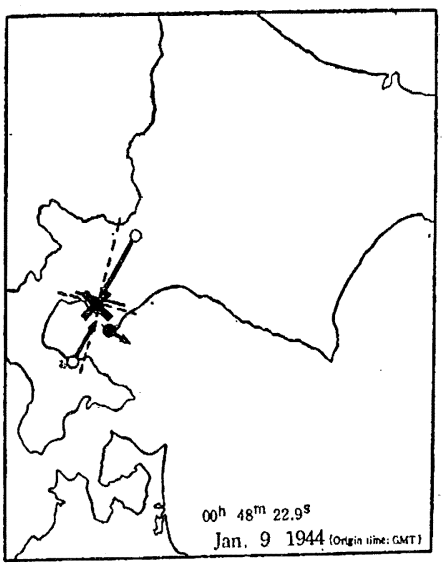

Depth of focus $H \fallingdotseq 25 \mathrm{~km}$

(b)

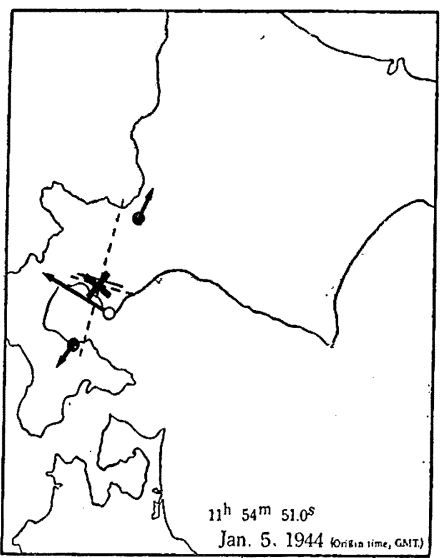

Depth of focus $H=11.1 \mathrm{~km}$

(a)

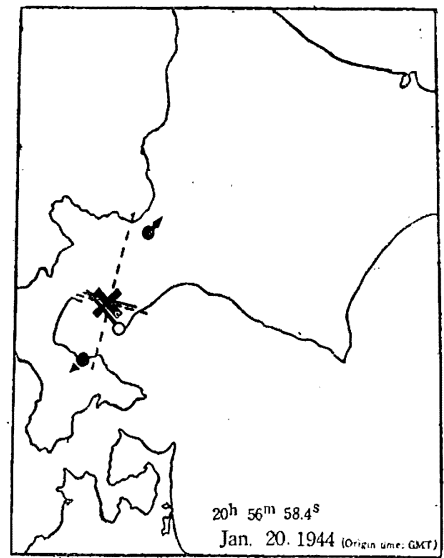

Depth of focus $H=10 \mathrm{~km}$

Fig. 7. Distribution maps of initial motion of $P$-waves in the Usu volcanic earthquakes, showing the so-called nodal lines (broken lines) and the direction of OusuKousu tectonic line (Solid lines).

solid dots: Compressional wave

open dots: Dilatational wave

(For determination of the representation of nodal lines, more data would be required. The present representation is a tentative one.)

angles.

Prof. Kenzô SAssa (1935-1936) pointed out in his valuable study of the volcanic activity of Volcano Aso (1932-1933) that the distribution of the initial motions near the volcano can be expressed by Prof. SHidA's "crack type".

\section{Discussion}

The depth of the hypocenters of the earthquakes that occurred during the activity of Showa Shinzan is really interesting. In the early stage of the activity, from December 1943 to January 1944, the magma lay at the depth of $10 \mathrm{~km}$ underground, but in July 1944, the early stage of explosion and upheaval at Fukaba, the magma rose by 1 to $4 \mathrm{~km}$ (T. Minakami and others, 1951). There is another point worth attention, that is, the depth of the hypocenter of the earthquakes of January 9 was 20 odd $\mathrm{km}$ which was obtained from the travel-time as shown in Fig. 8, whereas 
the records of the reflection waves S' suggest the existence of a discontinuity (Moho plane ?) at an average depth of $25 \mathrm{~km}$.

Why none of the forerunning earthquakes has the hypocenter as deep as $25 \mathrm{~km}$ or more? The fact that the new lava of Showa Shinzan(like the cases of Ousu and Kousu) is extremely acidic containing about $70 \% \mathrm{SiO}_{2}$, implies that the lava was not directly derived from the layer of such basic rocks as basalt or peridotite beneath the Moho layer, and that a basaltic magma may have formed a magma chamber at a depth of about $10 \mathrm{~km}$ and dissolved the sialic crust and thus became acidic.

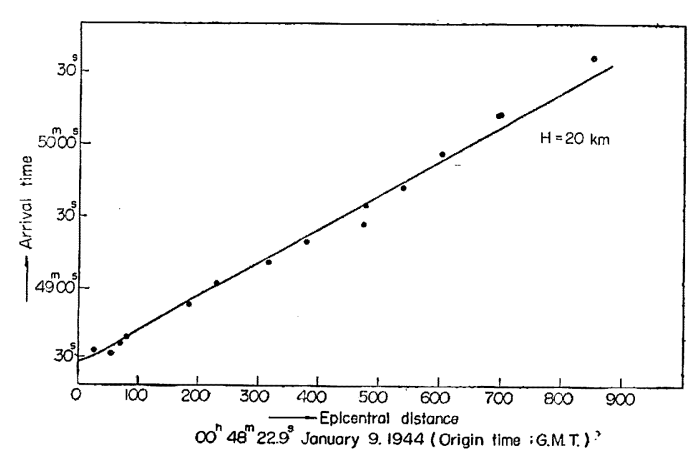

Fig. 8. Time-distance relation of the earthquake on Jan. 9, 1944. The travel time curve is by K. Wadati, S. Sagisaka and K. Masuda(1933). When the magma of such depth commenced its activity, it would cause earthquakes having the hypocenter at about $10 \mathrm{~km}$ (although it is possible that the magma is connected with other magma beneath the Moho layer at $25 \mathrm{~km}$, so that the deepseated magma causes earthquakes). Thus, one need not assume an especially resistant layer at about $10 \mathrm{~km}$ through which the deep-seated magma rises causing earthquakes. If the above assumption were not correct, then the seismograph should have recorded the earthquakes occurring at much greater depth than the seat of the magma, but we have no such records. The existence of a magma chamber or reservoir may be open to discussion. However, much of andesitic lava is supposed to have resulted from the magma's assimilation of the crust, and it cannot be considered to have come up from a deeper place at the time of the activity. Therefore, in the case of Showa Shinzan, it is highly plausible that a reservoir of andesitic magma occurs at a depth of about $10 \mathrm{~km}$, and the magma, with its fluidal movement and changing volume, brings about the initial earthquakes. It is also possible that the magma is connected with other magma in a deeper place, and both of them work together. Considering that the volcanic activity of the Chokai and the Norikura volcanic zones belong to this type, as T. IsHikAwA (1959) maintains, the diversified lithologic charac-

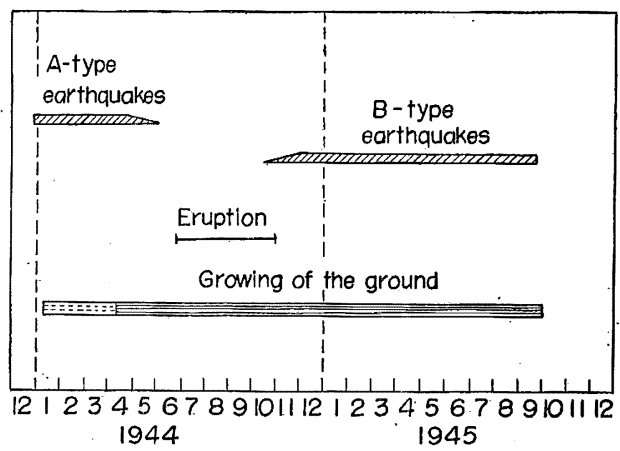

Fig. 9. Activities of the period that formed the new dome "Showa-Shinzan" (Dec. 28, 1943-Oct. 1, 1945). ters of lavas may be explained.

The writer hopes to have an opportunity in future of discussing the mechanism of occurrence of earthquakes affording sufficient data.

5. Earthquakes and ground upheaval accompanying the birth of ShowaShinzan

\section{Introduction}

Volcano Usu facing Lake Toya was strikingly active during the period from December 28, 1943 to October 1, 1945, 
accompanied by such marked phenomena as earthquakes, eruptions and upheaval of the ground. The activity is illustrated in Fig. 9.

The seismographs at Sapporo, Mori and Muroran Observatories recorded this volcanic activity. Besides the above records, there is the Mimatsu diagram(1948) which diagrammatized the profile of the Showa-Shinzan according to the macroscopic monthly observations. On the basis of these data the writer analyzed and studied the following points:

a. Time variations of the frequency of A-type earthquakes

b. Time variations of the amplitude of A-type earthquakes

c. Calculation of earthquake energy

d. Calculation of energy of ground upheaval

e. Relation between B-type earthquakes and ground upheaval (analysis of the B-type earthquakes)

\section{a. Time variations of the frequency of earthquakes}

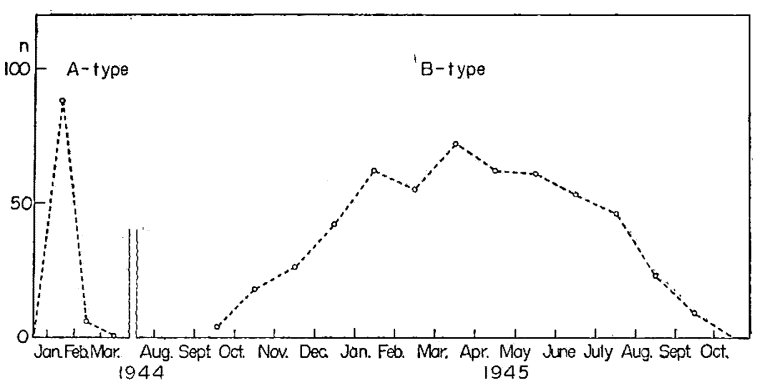

Fig. 10. Frequency-distribution of the Usu earthquakes from Dec. 1943 to Oct. 1945 as observed at Sapporo.
Fig. 10 shows the monthly totals of the time variations of earthquakes observed at Sapporo. All earthquakes, large and small, were counted (see also Table 8-a, b). A detailed consideration of the variations will be stated later.

\section{b. Time variations of the amplitude of earthquakes}

The earthquake waves were classified into several stages according to their amplitude. Time variation of the number of earthquakes in each stage is illustrated in Figs. 11, a and b.

When the A-type earthquakes were studied in detail (see Figs. 11-a and 12), it was known that the activity began with numerous minor earthquakes, which gradually became larger until January 9 when an earthquake of the largest scale occurred.

In the B-type earthquakes, as Fig. 11-b shows, an interesting phenomenon is noticed. That is, the number of earthquakes of each stage shows a pyramidal distribution, with the peak of the activity at the end of May 1945. While the occurrence of the A-type earthquakes is extended over about six months, the B-type earthquakes of a smaller scale are larger in number, being extended for a long period of more than a year. This is a noticeable difference between the A-type and the B-type earthquakes.

\section{c. Calculation of earthquake energy}

The earthquake energy was calculated by obtaining the value of magnitude $M$ first, and then by using the formula of Gutenberg-Richter.

Tentatively, the magnitude $M$ was obtained from Tsubor's formula (1954) 


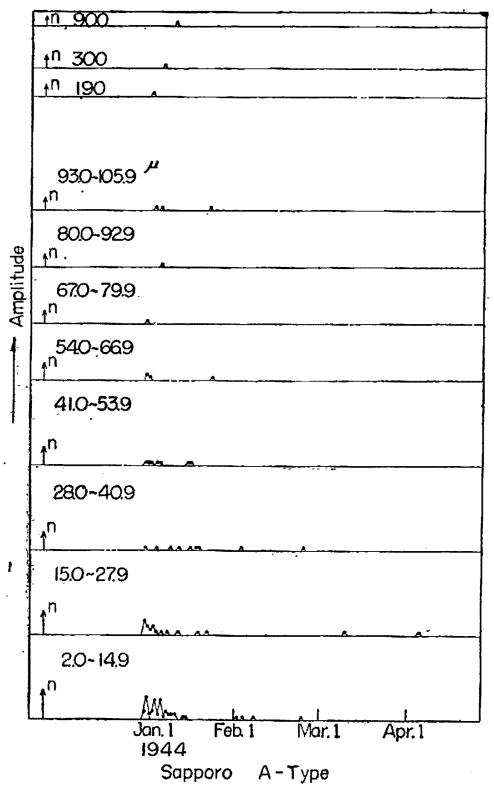

(a)

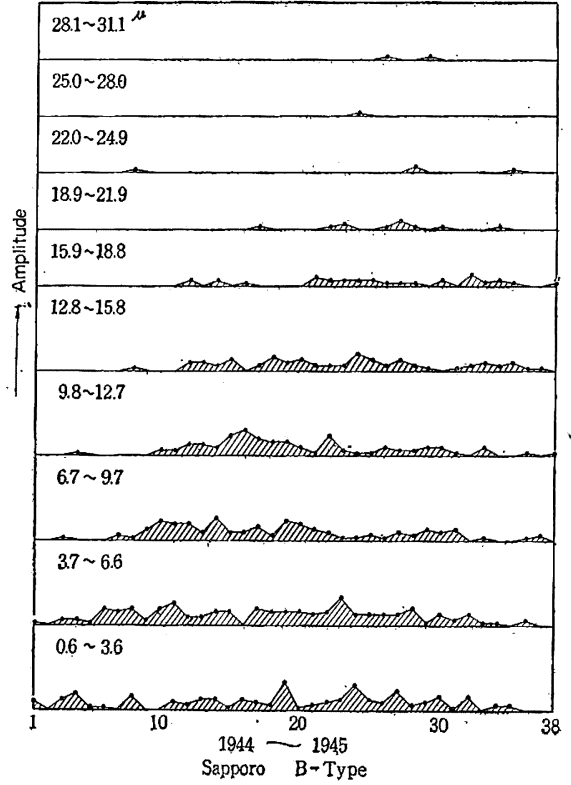

(b)

Fig. 11. Frequency of the earthquakes severally graded by their amplitudes. (the axis of abscissa is the number of divided ten days from Sept. 13, 1944.)

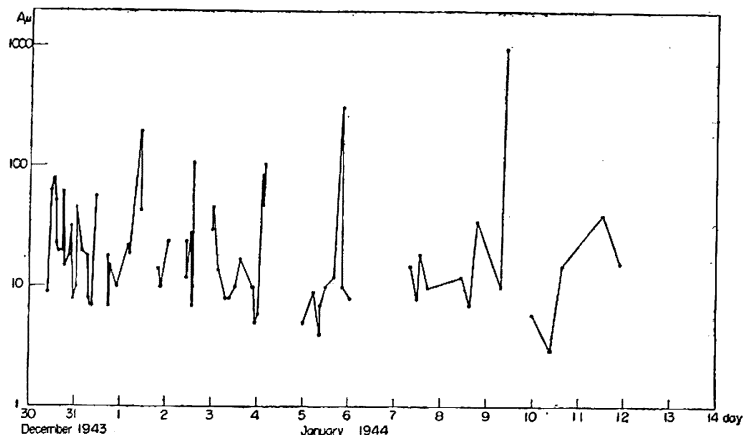

$M=1.73 \log \Delta+\log A-0.83$,
Fig. 12. Amplitude-distribution of the A-type (N-comp.) earthquakes from Dec, 30, 1943 to Jan. 13, 1944 as observed at Sapporo.

Showing the beginning of A-type earthquakes and appearance of the largest earthquake on Jan. 9, 1944.

and earthquake energy $E$ from Gutenberg-Richter's formula (1956)

$$
\log E=9.4+2.14 M-0.054 M^{2},
$$

where $A$ is the maximum amplitude of the earthquakes at the observation point located at $\Delta \mathrm{km}$ in epicentral distance, and the unit is in micron.

i) Total energy of earthquakes

From the observation data at Sapporo total energy of earthquake was calculated 

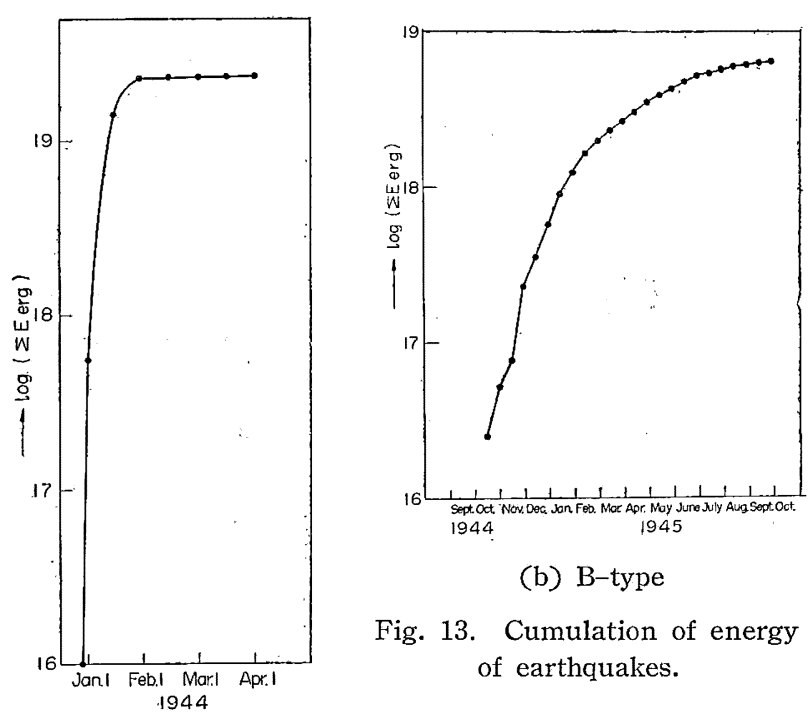

(b) B-type

Fig. 13. Cumulation of energy of earthquakes.

(a) A-type

earthquakes.

ii) Time variation of earthquake energy

In order to know the time variation of B-type earthquake energy, the data of about one month were used and a daily mean of the energy variation was diagrammatized.

\section{d. Calculation of energy of ground upheaval}

In order to obtain the energy of ground upheaval, the writer calculated the amount of increase in the potential energy

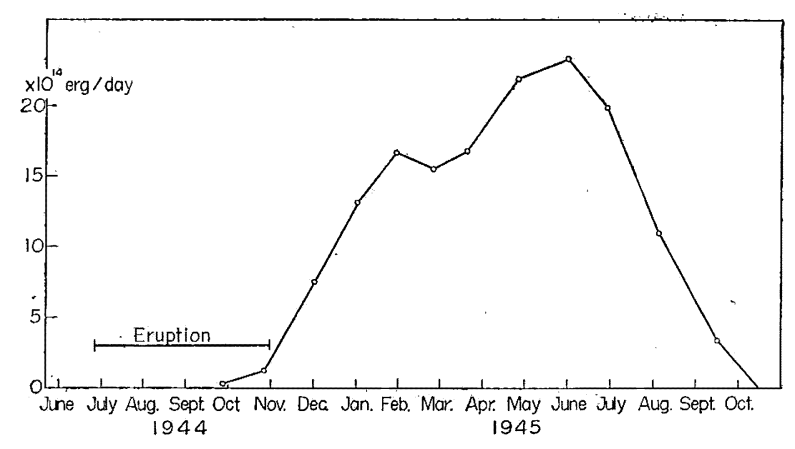

Fig. 14. Distribution of energy of B-type earthquakes. against gravity, or the work to as follows for the A-type earthquakes that occurred before the eruptive activity and for the B-type earthquakes that occurred after the eruption.

Total energy of A-type earthquakes: $11.5 \times 10^{18}$ ergs.

Total energy of B-type earthquakes: $6.09 \times 10^{18} \mathrm{ergs}$. Logarithms of cumulative energy of $A$ and $B$-type earthquakes with the stream of time are plotted in Fig. 13.

The total energy of the A-type earthquakes is about twice that of the B-type be done to raise the lava dome. For the calculation, various assumptions must be made. It should be kept in mind, therefore, that the resultant values represent only the relative changes and rough estimates.

In the first place it is assumed that the moving part of the strata to be considered in calculation is located above sea level, by seeing the movement of ground upheaval.

As the figure shows, the liquid magma underground rises to the sea level and pushes up the mountain body being formed on it. The work accomplished by the magma is calculated as the energy of upheaval (amount of increased potential energy against gravity). 


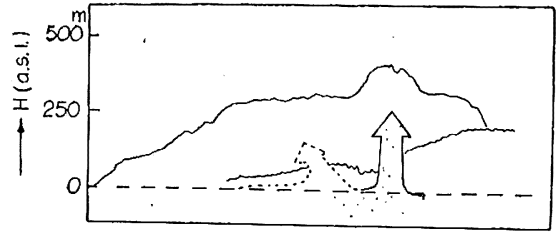

Fig 15. Imagined motion of magma.

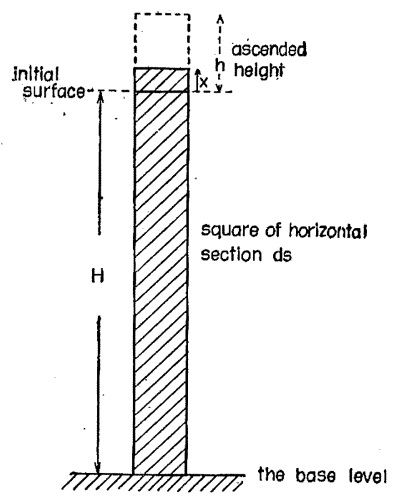

Fig. 16. A model for the calculation of increased potential energy by the upheaval of the roof mountain.
The mechanism of the upheaval is assumed as indicated in Fig. 16.

Suppose a base level on which lies the strata to be taken into consideration in calculation of the work done to raise the lava dome, and suppose that a surface element with its horizontal section of $d s$, which is initially at a height of $H$ from the base level, is uplifted by $h$. The volume increased by the uplift is continuously pushed up from under the base level.

When the surface is raised by $x(o \leqq$ $x \leqq h)$, the work done for raising the volume, $(H+x) d s$ as much as $d x$ is $\rho g(H+x) d s$ $d x$. Then the work $d w$ for raising the surface element from $x=o$ to $x=h$ becomes

$d w=\int_{0}^{h} \rho g(H+x) d s d x=\rho g h\left(H+\frac{h}{2}\right) d s$,

where $g$ is the acceleration of gravity. Thus the whole work $W$ for the upheaval of area $S$ becomes

$$
W=\int_{\mathrm{S}} d w=\int_{\mathrm{S}} \rho g h\left(H+\frac{h}{2}\right) d s,
$$

where $h \cdot d s$ is the upraised volume.

In actual calculations, the Mimatsu diagram (1949) which is the record of topographic observations for about one month, was used, and the mountain body was assumed as a semi-rotational body (the entire mountain body is divided into two parts, and each part is thought to rotate as much as $\pi$ ). The upraised volume was obtained by letting the transverse area of the uplifted part during each period rotate as much as $\pi$ around the center $O$. As Fig. 17 shows in detail, the

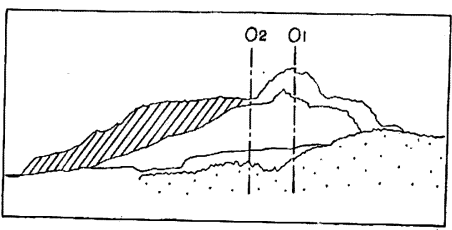

Fig. 17. Calculation of potential energy increased by the new-dome-formation. part marked with oblique lines rotates around $O_{2}$, and the other part around $O_{1}$, both as much as $\pi$, and respectively to the right and to the left. The base level was settled at sea level, as already mentioned. Thus, by subdividing the transverse area of the uplifted part into several portions and by using the symbols $\Delta S_{i}$ for the transverse area $i, r_{i}$ for the perpendicular line from the center of the area to the median axis, and $H i$ for the height from the sea level, the energy of upheaval can be calculated by the following formula:

$$
W=\sum_{i} \pi \rho g r_{i} H_{i} \Delta S_{i} .
$$


Fig. 18-a is a cumulation graph of upheaval energy, and the daily variation of mean upheaval energy is illustrated in Fig. 18-b.

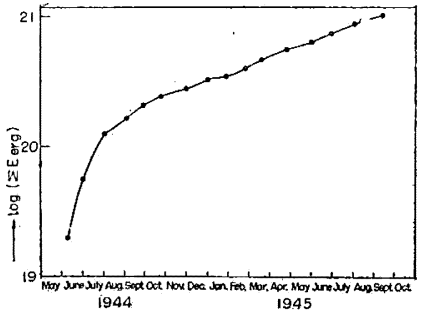

Fig. 18-(a). Cumulation of potential energy. (May. 25, 1944-Oct. 1, 1945)

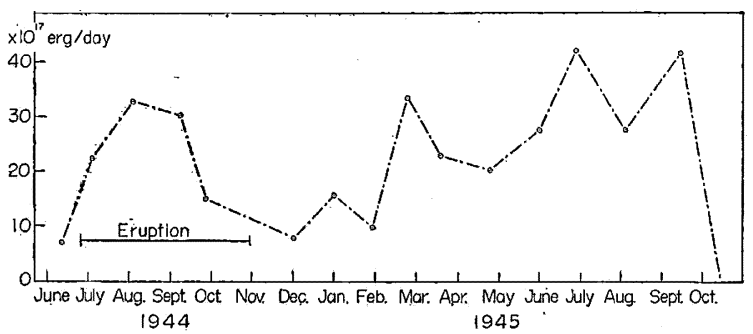

Fig. 18-(b). Distribution of the daily averaged grown potential energy for the ground upheaval.

\section{e. Relation between B-type earthquakes and ground upheaval (discussion for analysis of the B-type earthquakes)}

i) Frequency and energy of the earthquakes

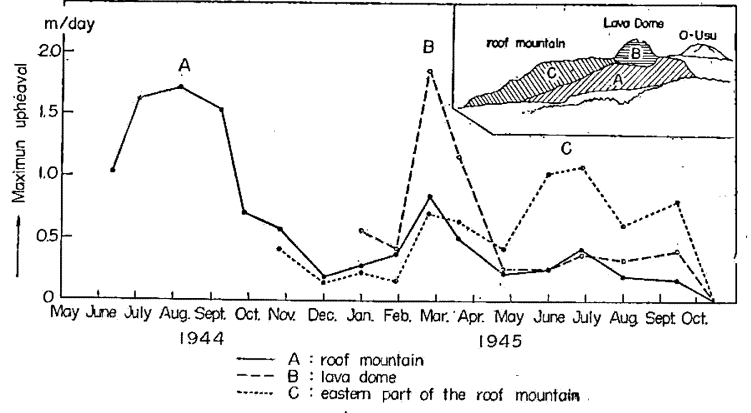

Fig. 19. Activities of the period that formed the new dome "Showa-Shinzan".
The B-type earthquakes culminated toward the end of May, 1945, when the maxima of amplitude and energy were recorded. However, the frequency of earthquakes was largest in February of that year, although the number was decreased at the supposed peak. From this fact, it is known that the number and the energy of earthquakes are not proportional.

ii) Relation between the frequency of earthquakes and the uplifted part

During the period when the number of earthquakes is supposed to become largest, the dome is active. In actuality, however, the number of earthquakes is diminished when the activity of the dome culminates. During the active period of the dome the scale of the earthquakes is smaller, as indicated in Fig. 20. These phenomena suggest the following: Numerous and minor earthquakes associated with the dome's activity have tendency to occur consecutively when the activity of the dome is suppressed, so that the earthquakes may not be caused by the dome's activity only.

iii) Energy of ground upheaval and that of earthquakes

Part (A) in the above figure indicates that an extensive area centering at the 
crater was upraised by a great energy. However, the seismic waves recorded by the seismograph were very few. Besides, the quantity of accumulated volcanic bombs due to eruptions is unknown. Hence, discussion on the upheaval is difficult.

Part (B) corresponds to the period of marked upheaval of the dome. As a matter of course, the energy of upheaval increased. But the energy of seismic waves was at a standstill. In the culminant period of the B-type earthquakes, i.e., in May, the energy of seismic waves is thought to show natural and smooth changes. Therefore, the above-mentioned stagnancy energy may be interpreted as the result of the energy being consumed in the form of upheaval energy. The energy of underground activity that brings about various volcanic phenomena, such as earthquakes, ground upheavals and eruptions, seems to come from a same source. In other words, there is no separate source of energy

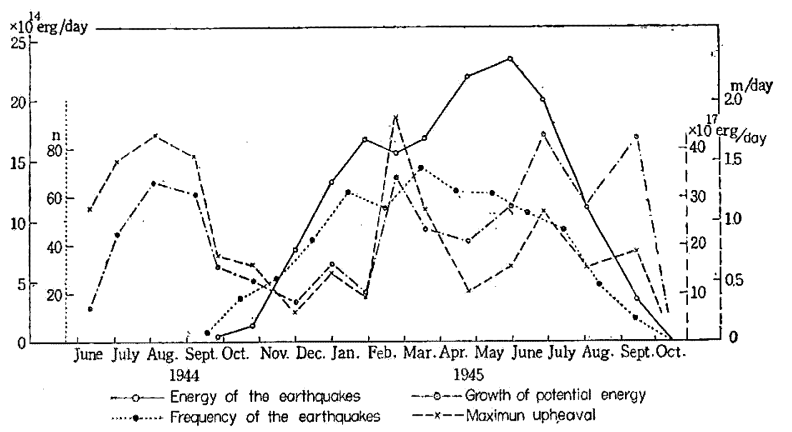

Fig. 20. Partial upheaval around the new dome "Showa-Shinzan",

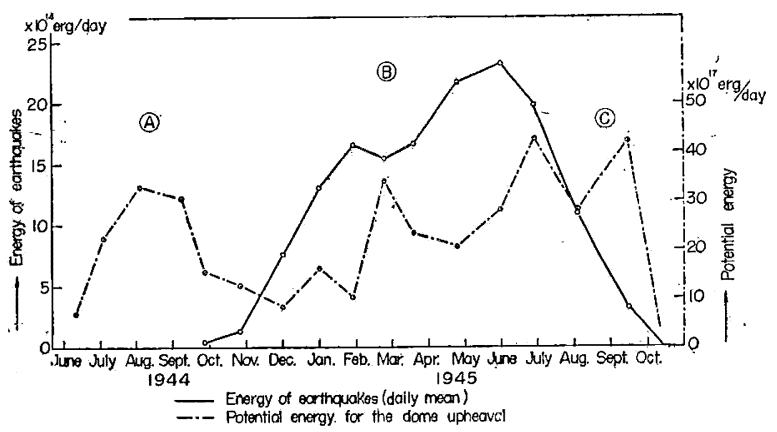

Fig. 21. Relation between the energy of B-type earthquakes and the potential energy for the upheaval of lava dome.

for earthquakes only, or for ground upheavals, and the like, but the energy exists as one and the same source, from which each of all these phenomena is produced according as the surrounding conditions vary.

Part (C) indicates that the energy of seismic waves gradually declined after its culmination. It is suggested that the volcanic activity was going to terminate, whereas the upheaval energy increased owing to the new uprising movement at the foot of the mountain. This uprising movement, as in the case of (A), is not accompanied by seismic waves. This phenomenon may be explained by assuming a volume expansion due to the falling temperature. Otherwise, it can be explained as follows.

After the volatile components of the magma were volatilized out during the previous eruption, the markedly viscous magma, characteristic of Volcano Usu, was moved by the last underground energy and advanced to the surrounding field where it could conduct a relatively free movement which was not large enough to cause seismic waves. This does not go beyond an imagination. At any rate, in this case the underground energy for the formation of Showa Shinzan after the eruptive 
Table 8. The daily frequency of the earthquake swarms of more than 3 microns of maximum amplitude observed by seismographs at the Mori $(\Delta=54 \mathrm{~km})$ and Sapporo Observatory $(\Delta=69 \mathrm{~km})$. during December, 1943-September, 1945.

A type earthquakes: Dec., 1943-Apr., 1944 B type earthquakes: Sept., 1944-Sept., 1945

\begin{tabular}{|c|c|c|c|c|c|c|c|c|c|c|c|c|c|c|}
\hline & \multicolumn{2}{|c|}{\begin{tabular}{|r|r|} 
Mo- & Sap- \\
ri & poro \\
\end{tabular}} & Date & \multicolumn{2}{|c|}{\begin{tabular}{|} 
Mo- \\
ri \\
pap-ro
\end{tabular}} & Date & \multicolumn{2}{|c|}{ 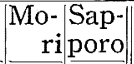 } & Date & \multicolumn{2}{|c|}{$\begin{array}{r}\text { Mo- } \\
\text { ri } \\
\text { pap- } \\
\end{array}$} & Date & \multicolumn{2}{|c|}{$\begin{array}{r}\text { Mo- } \\
\text { ri } \\
\end{array}$} \\
\hline & & & & & & $17-30$ & & & & & & & & \\
\hline 1943 & 1 & & 1944 & & & 1944 & & & 23 & 1 & $\begin{array}{l}2 \\
3\end{array}$ & 11 & & $\begin{array}{r}2 \\
0\end{array}$ \\
\hline $\begin{array}{ll}29 \\
29\end{array}$ & 18 & $\begin{array}{l}0 \\
5\end{array}$ & Mar. $\begin{array}{l}1 \\
2\end{array}$ & 1 & $\begin{array}{l}0 \\
0\end{array}$ & $\begin{array}{ll}\text { Oct. } & 1 \\
& 2\end{array}$ & & 0 & $\begin{array}{l}24 \\
25\end{array}$ & & $\begin{array}{l}3 \\
0\end{array}$ & $\begin{array}{l}12 \\
13\end{array}$ & & $\begin{array}{l}2 \\
2\end{array}$ \\
\hline 30 & 42 & 18 & 3 & & 0 & 3 & & 0 & 26 & & 2 & 14 & & 1 \\
\hline 31 & 22 & 12 & & & & 4 & & 0 & 27 & & $\overline{1}$ & 15 & & 2 \\
\hline 1944 & 23 & 7 & 4 & 1 & $\begin{array}{l}0 \\
0\end{array}$ & 5 & & 1 & 28 & & 1 & & & \\
\hline Jan. 1 & 23 & $\gamma$ & $\begin{array}{l}5 \\
6\end{array}$ & $\begin{array}{l}2 \\
0\end{array}$ & $\begin{array}{l}0 \\
0\end{array}$ & 6 & & 3 & $\begin{array}{l}28 \\
29\end{array}$ & & $\begin{array}{l}1 \\
0\end{array}$ & $\begin{array}{l}10 \\
17\end{array}$ & & $\begin{array}{l}3 \\
3\end{array}$ \\
\hline 2 & 18 & 8 & 7 & 1 & 0 & 7 & & 1 & 30 & & 5 & 18 & & 1 \\
\hline 3 & 28 & 11 & 8 & 1 & 0 & 8 & & 0 & 1944 & & & 19 & & 1 \\
\hline 4 & 15 & 5 & & & & 9 & & 0 & Dec. 1 & & 2 & 20 & & 0 \\
\hline & $\begin{array}{r}11 \\
6\end{array}$ & $\begin{array}{l}8 \\
2\end{array}$ & $\begin{array}{r}9 \\
10\end{array}$ & & $\begin{array}{l}0 \\
1\end{array}$ & 10 & 0 & 0 & 2 & & 0 & 21 & & 1 \\
\hline & & & 11 & & 0 & 11 & 0 & 0 & 3 & & 1 & 22 & & 2 \\
\hline 7 & 5 & 4 & 12 & 1 & 1 & 12 & & 1 & 4 & & 1 & 23 & & $\overline{2}$ \\
\hline 8 & 5 & 3 & $13-31$ & & 0 & 13 & & 1 & 5 & & 0 & 24 & & 4 \\
\hline 9 & 6 & 4 & 1944 & & & 14 & 0 & 0 & 6 & & 1 & 25 & & 3 \\
\hline 10 & 5 & 2 & Apr. 1 & 0 & 0 & 15 & 0 & 1. & 7 & & 0 & & & \\
\hline 11 & 7 & 2 & 2 & 0 & 0 & 16 & & 2 & 8 & & 0 & $\begin{array}{l}26 \\
27\end{array}$ & & $\begin{array}{l}1 \\
4\end{array}$ \\
\hline 12 & 4 & 0 & 3 & & 0 & 17 & & 1 & 9 & 1 & 1 & 28 & & 3 \\
\hline 13 & 3 & 1 & 4 & 0 & 0 & 18 & 0 & 0 & 10 & 1 & 1 & 29 & & 1 \\
\hline 14 & 4 & 1 & 5 & 0 & 1 & 19 & & 1 & 11 & 1 & 3 & 30 & & 4 \\
\hline 15 & 5 & 2 & $6-14$ & 0 & 0 & 20 & & 2 & 12 & & 0 & & & \\
\hline 16 & 0 & 0 & & & & & & & & & & 31. & & 1 \\
\hline 17 & 2 & 1 & $\begin{array}{r}15 \\
16-30\end{array}$ & 1 & $\begin{array}{l}0 \\
0\end{array}$ & 21 & & 0 & 13 & & 3 & 1945 & & \\
\hline 18 & 2 & $\begin{array}{l}1 \\
2\end{array}$ & 1944 & & 0 & $\begin{array}{l}22 \\
23\end{array}$ & & 1 & $\begin{array}{l}14 \\
15\end{array}$ & & 2 & Feb. $\begin{array}{l}1 \\
2\end{array}$ & & $\begin{array}{l}3 \\
3\end{array}$ \\
\hline 19 & 0 & 0 & May 1 & & 0 & 24 & 1 & 2 & 16 & & 1 & 3 & & $\begin{array}{l}3 \\
2\end{array}$ \\
\hline 20 & 0 & 0 & 2 & & 0 & 25 & 0 & 0 & 17 & & 2 & 4 & & 1 \\
\hline 21 & 2 & 2 & 3 & 0 & 0 & $26-31$ & & 0 & 18 & & 0 & 5 & & \\
\hline 22 & 2 & 1 & 4 & 0 & 0 & $\begin{array}{l}20-31 \\
1944\end{array}$ & & 1. & 19 & & 1 & 6 & & 1 \\
\hline 23 & 0 & 0 & 5 & & 0 & Nov. 1 & & 0 & 20 & & 2 & 7 & & 3 \\
\hline 24 & 0 & 0 & 6 & & 0 & 2 & & 1 & 21 & 1 & 1 & & & \\
\hline 25 & 3 & 1 & 7 & 0 & 0 & 3 & & 3 & & & & & & \\
\hline 26 & 0 & 0 & 8 & 1 & 0 & $\begin{array}{l}3 \\
4 \\
\end{array}$ & & 1 & $\begin{array}{l}22 \\
23\end{array}$ & & $\begin{array}{l}3 \\
2\end{array}$ & $\begin{array}{l}\circ \\
9\end{array}$ & & $\begin{array}{l}5 \\
2\end{array}$ \\
\hline 27 & 0 & 0 & 9 & 0 & 0 & 5 & & 0 & 24 & & 2 & 10 & & 2 \\
\hline 28 & 0 & 0 & & & 0 & 6 & & 0 & 25 & & 3 & 11 & & 1 \\
\hline 29 & 0 & 0 & $11-31$ & & 0 & 7 & & 1 & 26 & & 2 & 12 & & 3 \\
\hline $\begin{array}{l}30 \\
31\end{array}$ & 1 & 0 & 1944 & 0 & 0 & 8 & & 0 & 27 & & & 13 & & \\
\hline & 0 & 0 & $\begin{array}{ll}\text { June } & 1 \\
& 2\end{array}$ & 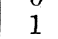 & 0 & a & & 1 & 28 & & 1 & 14 & & 1 \\
\hline 1944 & & & & & & 10. & & 0 & 29 & & 2 & 15 & & 3 \\
\hline Feb. $\quad 1$ & 1 & 1 & & & 0 & 11 & & 0 & 30 & & 2 & 16 & & 2 \\
\hline & 1 & 1 & $\begin{array}{r}4 \\
5-30\end{array}$ & & 0 & 12 & & 0 & $\begin{array}{r}31 \\
1945\end{array}$ & & 2 & 17 & & 3 \\
\hline $\begin{array}{l}3 \\
4\end{array}$ & $\begin{array}{l}1 \\
0\end{array}$ & $\begin{array}{l}1 \\
0\end{array}$ & $\begin{array}{r}5-30 \\
\text { July } 1-16\end{array}$ & & $\begin{array}{l}0 \\
0\end{array}$ & 13 & & 0 & $\begin{array}{l}1945 \\
\text { Jan. } 1\end{array}$ & 1 & 2 & 18 & 1 & 1 \\
\hline 5 & 0 & 0 & 17 & 1 & 0 & 14 & & 1 & $\overline{2}$ & 1 & 2 & 19 & & 2 \\
\hline & & & & & & 15 & 0 & 0 & 3 & & 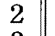 & 20 & 1 & 4 \\
\hline 6 & $\begin{array}{c}0 \\
2\end{array}$ & 0 & $\begin{array}{r}18-31 \\
A 1-31\end{array}$ & & $\begin{array}{l}0 \\
0\end{array}$ & 16 & 0 & 0 & 4 & & 3 & 21 & 2 & 3 \\
\hline $\begin{array}{l}7 \\
8-2\end{array}$ & 2 & 1 & & & 0 & 17 & & 0 & 5 & & 1 & 22 & & 1 \\
\hline 23 & 1 & 1 & Se & & & 18 & & 0 & 6 & & 2 & 23 & & 3 \\
\hline 24 & 2 & 2 & 13 & & 1 & 19 & & 1 & 7 & & 2 & 24 & & 0 \\
\hline & & & $12+2+2$ & & 1 & 20 & 0 & 2 & 8 & & 2 & 25 & & 1 \\
\hline $2 b-29$ & 0 & 0 & $\begin{array}{l}15 \\
16\end{array}$ & & $\begin{array}{l}1 \\
1\end{array}$ & $\begin{array}{l}21 \\
22\end{array}$ & 2 & $\begin{array}{l}1 \\
0\end{array}$ & $\begin{array}{r}9 \\
10\end{array}$ & & $\begin{array}{l}3 \\
3\end{array}$ & $\begin{array}{l}26 \\
27\end{array}$ & & 3 \\
\hline & & & & & & & & & & & & & & \\
\hline
\end{tabular}


-Continued-

\begin{tabular}{|c|c|c|c|c|c|c|c|c|c|c|c|c|c|}
\hline \multirow{3}{*}{\begin{tabular}{|c} 
Date \\
Mar. $^{28}$ \\
Mar.
\end{tabular}} & $\mid \begin{array}{r}\text { Mo- } \\
\text { ri }\end{array}$ & Date & \multicolumn{2}{|c|}{\begin{tabular}{|} 
Mo- \\
ri
\end{tabular} - pap-||} & Date & \multicolumn{2}{|c|}{$\begin{array}{r}\text { Mo- } \text { Sap- } \\
\text { ri poro }\end{array}$} & Date & \multicolumn{2}{|c|}{$\begin{array}{r}\text { Mo- } \text { Sap- } \\
\text { ri poro }\end{array}$} & \multirow{2}{*}{$\begin{array}{r}\text { Date } \\
10\end{array}$} & \multicolumn{2}{|c|}{$\begin{array}{r}\text { Mo- } \\
\text { ri poro- }\end{array}$} \\
\hline & & 18 & & 2 & 5 & 1 & $4 . \quad>\quad-$ & 23 & 1 & 3 & & 1 & 1 \\
\hline & 4 & 19 & & 3 & $\begin{array}{l}5 \\
6\end{array}$ & 1 & $\begin{array}{l}4 \\
1\end{array}$ & $\begin{array}{l}23 \\
24\end{array}$ & $\begin{array}{l}1 \\
1\end{array}$ & 2 & 11 & & $\begin{array}{l}1 \\
0\end{array}$ \\
\hline & 3 & 20 & & 3 & 7 & & 3 & 25 & 1 & 2 & 12 & & 0 \\
\hline 3 & 2 & 21 & & 1 & 8 & & 3 & 26 & 0 & 0 & 13 & 1 & 1 \\
\hline 4 & 1 & 22 & & 4 & 9 & & 3 & 27 & 2 & 2 & 14 & 0 & 0 \\
\hline 5 & 5 & 23 & & 0 & 10 & & 2 & 28 & 1 & 1 & 15 & & 0 \\
\hline 6 & 3 & 24 & & 5 & 11 & & 2 & 29 & 0 & 2 & 16 & 0 & 0 \\
\hline 7 & 3 & 25 & 2 & 3 & 12 & & 1 & 30 & 2 & 2 & 17 & 1 & 1 \\
\hline 8 & 1 & 26 & & 3 & 13 & & 2 & 31 & 0 & 0 & 18 & & 0 \\
\hline 9 & 1 & 27 & & 3 & 14 & & 1 & 1945 & & & 19 & 0 & 0 \\
\hline 10 & 4 & 28 & & 3 & 15 & & 4 & Aug. 1 & 1 & $I$ & 20 & 1 & 1 \\
\hline 11 & 0 & 29 & & 2 & 16 & & 2 & 2 & 1. & 0 & 21 . & & 0 \\
\hline 12 & 2 & 30 & & 3 & 17 & & 1 & 3 & 1 & 1 & 22 & & 0 \\
\hline 13 & 2 & 1945 & & & 18 & 1 & 2 & 4 & 1 & 1 & 23 & 0 & 0 \\
\hline 14 & 4 & May 1 & & 1 & 19 & 1 & 2 & 5 & & 1 & 24 & 0 & 0 \\
\hline 15 & 2 & & & 3 & 20 & 1 & 2 & 6 & & 1 & 25 & & 0 \\
\hline 16 & 5 & 3 & & 2 & 21 & & 2 & 7 & 1 & 2 & 26 & & 1 \\
\hline 17 & 1 & 4 & & 3 & 22 & 1 & 2 & 8 & 1 & 1 & 27 & & 0 \\
\hline 18 & 5 & 5 & & 2 & 23 & 1 & 1 & 9 & 1 & 1 & 28 & & 0 \\
\hline 19 & 2 & 6 & & 2 & 24 & & 0 & 10 & 2 & 0 & 29 & & 0 \\
\hline & & 7 & & 3 & & & & 11 & 2 & 1 & & & \\
\hline 20 & 3 & & & & 25 & 0 & 1 & & & & 30 & & 0 \\
\hline 21 & 3 & 8 & & 6 & 26 & 1 & 2 & 12 & & 2 & & & \\
\hline 22 & 5 & 9 & & 3 & 27 & & 2 & 13 & & 1 & & & \\
\hline 23 & 0 & 10 & & 2 & 28 & 1 & 1 & 14 & & 1 & & & \\
\hline 24 & 1 & 11 & & 0 & 29 & 2 & 2 & 15 & 0 & 0 & & & \\
\hline & & 12 & & 1 & & & & 16 & 1 & 1 & & & \\
\hline 25 & 2 & & & & 30 & 1. & 1 & & & & & & \\
\hline 26 & 2 & 13 & & 2 & 1945 & & & 17 & 1 & 2 & & & \\
\hline 27 & 0 & 14 & & 3 & July & & 1 & 18 & 0 & 0 & & & \\
\hline 28 & 4 & 15 & 3 & 3 & 2 & & 1 & 19 & & 3 & & & \\
\hline $20-2$ & 3 & 16 & 1 & $n$ & & 0 & 2 & 20 & 0 & 0 & & & \\
\hline 30 & $\begin{array}{l}3 \\
2\end{array}$ & $\begin{array}{l}10 \\
17\end{array}$ & 1 & 2 & $\begin{array}{l}3 \\
4\end{array}$ & 2 & 1 & 21 & 1 & 1 & & & \\
\hline 31 & 3 & 18 & 1 & 1 & 5 & & 5 & 22 & 1 & 1 & & & \\
\hline 1945 & & 19 & & 1 & 6 & & 0 & 23 & & 0 & & & \\
\hline Apr. & 1 & 20 & & 3 & 7 & 1 & 2 & 24 & 1 & 1 & & & \\
\hline & 2 & & & & & & & 25 & & 0 & & & \\
\hline & & 21 & 1 & 1 & 8 & 1 & 3 & & & & & & \\
\hline 3 & 2 & 22 & & 1 & 9 & 1 & 2 & 26 & & 0 & & & \\
\hline 4 & 2 & 23 & & 1 & 10 & 1 & 2 & 27 & 0 & 0 & & & \\
\hline 5 & 1. & 24 & & 3 & 11 & & 0 & 28 & 1 & 1 & & & \\
\hline 6 & 1 & 25 & & 3 & 12 & & 2 & 29 & & 0 & & & \\
\hline 7 & 2 & & & & & & & 30 & & 1 & & & \\
\hline & & 26 & & 2 & 13 & 1 & 1 & & & & & & \\
\hline 8 & 0 & 27 & 1 & 1 & 14 & 2 & 1 & 31 & & 0 & & & \\
\hline 9 & 4 & 28 & & 3 & 15 & 1 & 0 & 1945 & & & & & \\
\hline 10 & 2 & 29 & 1 & 1 & 16 & 2 & 2 & Sept. 1 & 1 & 1 & & & \\
\hline 11 & 5 & 30 & & 2 & 17 & 1 & 0 & 2 & & 1 & & & \\
\hline 12 & 2 & & & & & & & 3 & 0 & 0 & & & \\
\hline & & 31 & 1 & 3 & & & & 4 & 1 & 1 & & & \\
\hline 13 & 1 & 1945 & & & 18 & 1 & 1 & & & & & & \\
\hline 14 & 2 & June 1 & & 3 & 19 & 0 & 0 & 5 & 0 & 0 & & & \\
\hline 15 & 2 & 2 & & 2 & 20 & 1 & 1 & 6 & 1 & 1 & & & \\
\hline 16 & 0 & 3 & & 2 & 21. & 1 & 4 & 7 & 0 & 0 & & & \\
\hline 17 & 3 & 4 & 1 & 1 & 22 & 0 & 1 & $\begin{array}{l}8 \\
9\end{array}$ & 0 & $\begin{array}{l}0 \\
0\end{array}$ & & & \\
\hline
\end{tabular}


activity cannot be considered to show a gradual decrease toward the end. As a matter of fact, no final conclusion could be reached before a synthetic study is made on the nature of magma, the mechanism of volcanic activity, etc.

\section{Two New Phases observed at Mori Observatory*}

\section{Introduction}

The volcanic activity of Volcano Usu from 1943 to 1945, which gave birth to Showa Shinzan, was accompanied by numerous earthquakes. Among the seismic waves recorded then, there were observed two new phases having remarkably slow

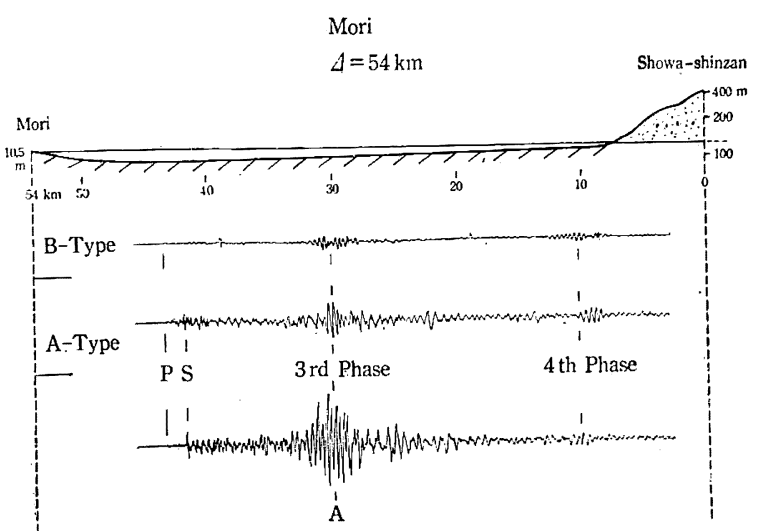

Fig. 22. Cross section of the path between hypocenter (Showa-Shinzan) and Mori Observatory and patterns of the A-type and the B-type earthquake recorded at Mori Observatory. group velocities. These special phases were detected only when the propagation path ran through the sea. The writer tentatively named them the third and fourth phases, respectively. They were recorded by the Wiechert seismograph at Mori Observatory which is situated at a place to which the direct path from the hypocenter is mostly through shallow sea water.

Mode of occurrence of $3 r d$ and 4 th phases

Mori Observatory is located at $\lambda: 140^{\circ} 34^{\prime} E$ and $\varphi: 42^{\circ} 06^{\prime} N$, $\Delta=54 \mathrm{~km}, S 27^{\circ} \mathrm{W}$ of Volcano

Usu, the hypocenter. As Fig. 22 shows, most part of the propagation path lies in shallow water. The two new phases did not occur when the seismic waves were propagated over a land jath, as shown in Fig. 23. The waves form of the third and the fourth phases somewhat differed between the A-type earthquakes that occurred prior to the eruptions (December 1943-April 1944) and the B-type earthquakes associated with the lava dome upheaval after the eruptions (September 1944-October 1945), but the lapse of time from the $P$-waves was nearly uniform in all earthquakes recorded throughout the active period (see section 2 of this report). The seismograms at Mori Observatory which recorded about 1,400 earthquakes revealed that the wave forms of the two phases were identical even to the details; the likeness was especially striking in the B-type earthquakes. The $3 \mathrm{rd}$ phase was distinctively observed in the A type earthquakes, but the occurrence of the 4th phase was less frequent and on a minor scale. In the B-type earthquakes, on the other hand, both phases were observed quite distinctively.

Such differences as mentioned above may be due to the different depths of the hypocenters of A-type and B-type earthquakes, because the hypocenter of the Atype earthquake is considered to lie at about $10 \mathrm{~km}$ below the ground surface

\footnotetext{
* Takashi Kizawa, 1960.
} 

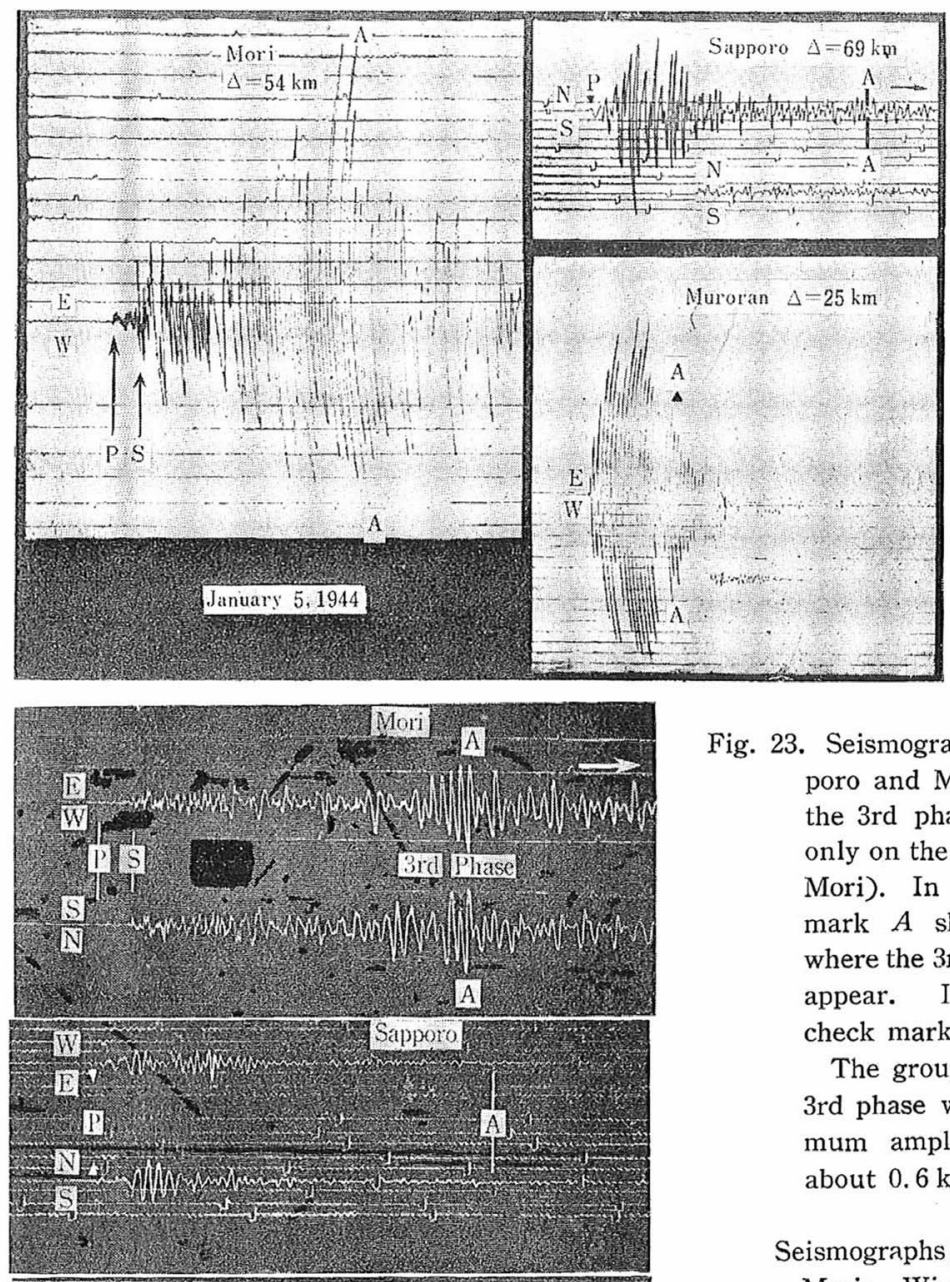

Fig. 23. Seismograms at Mori, Sapporo and Muroran, showing the 3rd phase that appeared only on the water path(UsuMori). In these figure the mark $A$ shows the point where the 3rd phase seems to appear. Interval of time check marks is one minute.

The group velocity of the 3rd phase where the maximum amplitude appears is about $0.6 \mathrm{~km} / \mathrm{sec}$.

\section{Seismographs;}

Mori : Wiechert-type

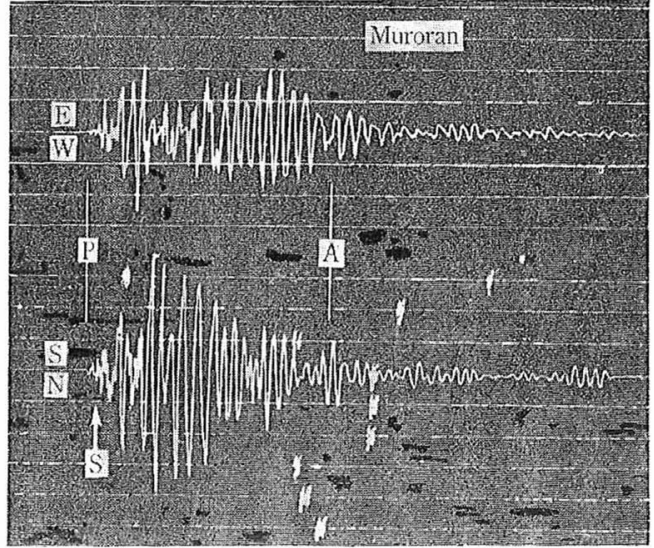

Magnification: $V_{N}=83$, $V_{E}=82$

Period: $\quad T_{0 N}=4.1 \mathrm{sec}$, $T_{0 E}=4.2 \mathrm{sec}$

Sapporo: Wiechert-type

Magnification: $V_{N}=101$,

$$
V_{E}=110
$$

Period: $\quad T_{0 N}=5.5 \mathrm{sec}$, $T_{0 E}=4.6 \mathrm{sec}$

Muroran: Oomori-type

Magnification: $\quad V_{N}=50$,

$$
V_{E}=50
$$

Period:

$$
\begin{aligned}
& T_{u N}=4 \mathrm{sec}, \\
& T_{0 E}=4 \mathrm{sec}
\end{aligned}
$$

(Section 1) and that of the B-type earthquakes is supposed to occur at a very shallow depth, i.e. less than $1 \mathrm{~km}$ (See the author's previous papers). 
The examples of seismograms of A-type and B-type earthquakes are illustrated in Fig. 24 to show the differences of the two types and the mode of occurrence of the 3 rd and 4 th phases.
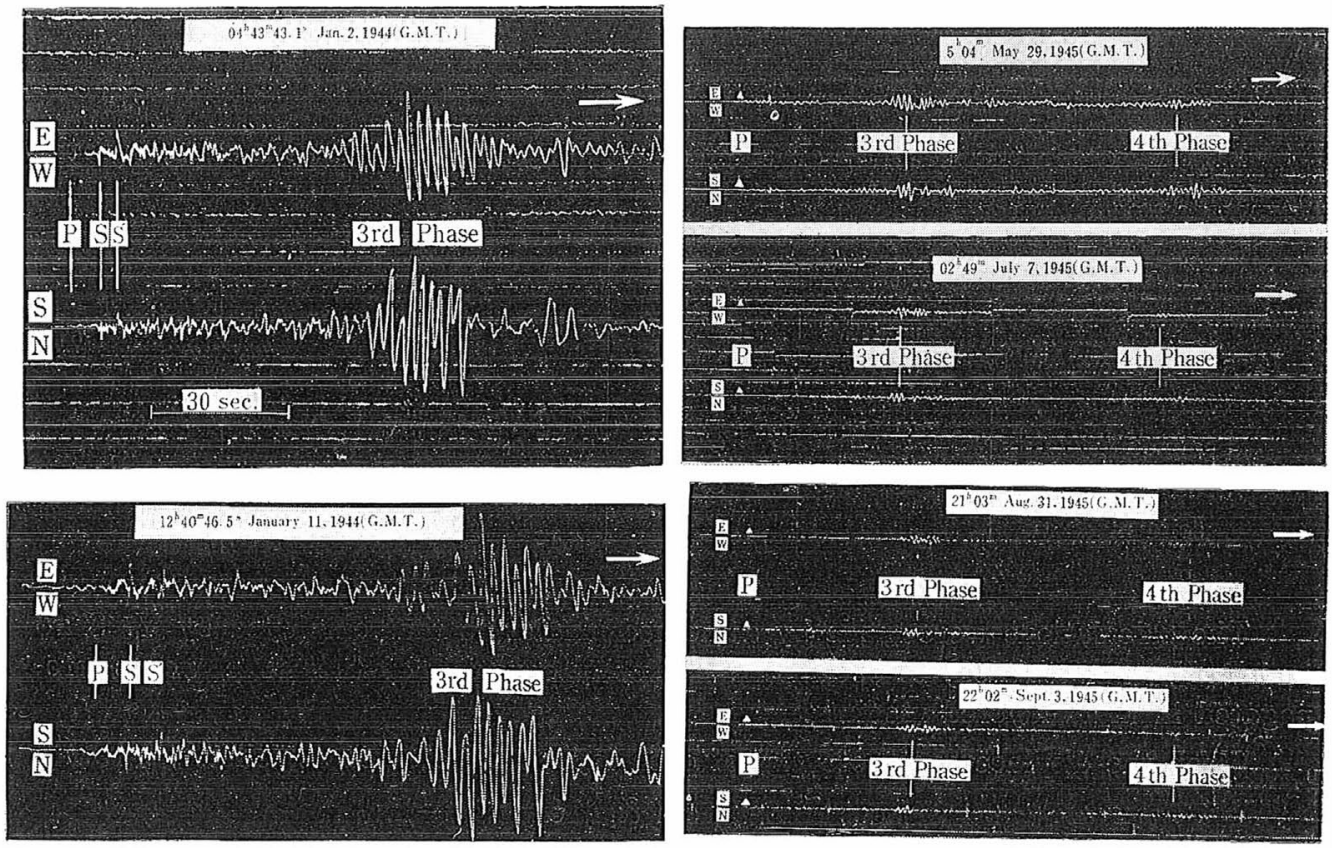

(a) A-type

(b) B-type

Fig. 24. Seismograms of earthquakes recorded at Mori Observatory, Hokkaido.

Mori Wiechert seismograph. Interval of time check marks is one minute

Magnification: $V_{N}=83, \quad V_{E}=82$

Period. $T_{i, N}=4.1 \mathrm{sec} . \quad T_{i, E}=4.2 \mathrm{sec}$

\section{Dispersion curves of Rayleigh waves}

For explanation of the two new phases introduced above, the writer treated them as Rayleigh waves* and pursued the Rayleigh-wave dispersion. This work** was done using the I.B.M. 704 electronic computer in co-operation with Mr. R. Yamaguti.

We first assumed two liquid layers, a water layer and a sedimentary layer, both of which overlie a semi-infinite solid medium.

Then, assuming that the velocity of compressional wave in the sedimentary layer is lower than that in the water layer, the dispersion curves of Rayleigh waves were calculated for various cases.

As is already reported by the writer (1958), the analytical study of the wave trains of the two new phases disclosed that the phases have chacracters in common with the Rayleigh wave.

The results obtained from the IBM 704 electronic computer for the above model are shown in Fig. 37. (See also Tables 10, 11, 12)

*Cf.: Pekeris, C. L. $(1948,1958,1959)$; Press, F. and others $(1950,1951)$.

**Cf.: T. Kizawa and R. Yamaguti (1960). 
However, these results failed to coincide with the results of actual observation which showed that the velocity and the period of $3 \mathrm{rd}$ phase are $V=0.6 \mathrm{~km} / \mathrm{sec}$ and $T=c a$. $2 \mathrm{sec}$, as shown in Table 13. Thereupon, the writer considered another case "liquid-solid-solid" for explanation of the 3rd and 4th phases.

\section{The case of (liquid-solid-solid) structure}

In this case, the second, or sedimentary, layer is treated as a solid, and the symbols used in the consideration are shown below.

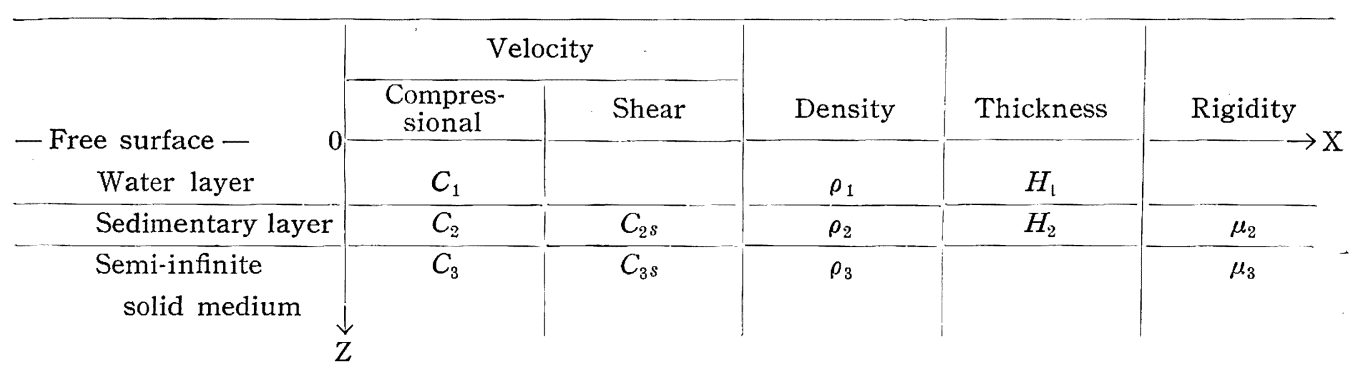

The calculations were made by a method similar to that employed by Y. SATô and R. Yamaguti (1959) to obtain the "velocity equation of the Love waves propagated in multi-layered media".

When the displacement potential of each layer is considered as follows,

$$
\begin{aligned}
& \phi_{1}=\left\{A_{1} \cos \tilde{\alpha}_{1} z+B_{1} \sin \tilde{\alpha}_{1} z\right\} \text { exp }\{\text { ipt-ifx }\} \\
& \phi_{2}=\left\{A_{2} \cos \tilde{\alpha}_{2} z+B_{2} \sin \tilde{\alpha}_{2} z\right\} \text { exp }\{\text { ipt-ifx }\} \\
& \Psi_{2}=\left\{C_{2} \cos \widetilde{\beta}_{2} z+D_{2} \sin \widetilde{\beta}_{2} z\right\} \text { exp }\{\mathrm{ipt}-\mathrm{ifx}\} \\
& \phi_{3}=F_{3} \exp \left\{-\alpha_{3} z\right\} \exp \{\mathrm{ipt}-\mathrm{ifx}\} \\
& \Psi_{3}=F_{3} \exp \left\{-\beta_{3} z\right\} \exp \{\mathrm{ipt}-\mathrm{ifx}\}
\end{aligned}
$$

where

$$
\begin{aligned}
& \alpha_{k}=f \sqrt{1-\left(C / C_{k}\right)^{2}}=i \quad \tilde{\alpha}_{k}, \quad(k=1,2,3) \\
& \beta_{k}=f \sqrt{ } 1-\left(C / C_{k_{s}}\right)^{2}=i \quad \widetilde{\beta}_{k}, \quad(k=2,3)
\end{aligned}
$$

and $C$ is the phase velocity. The wave length and period are expressed as $L=$ $\frac{2 \pi}{f}$ and $T=\frac{2 \pi}{p}$, respectively. Since the displacement and the stress are in the following relation:

$$
\begin{aligned}
& \left\{\begin{array}{l}
u=\frac{\partial \phi}{\partial x}+\frac{\partial \Psi}{\partial z}, \\
w=\frac{\partial \phi}{\partial z}-\frac{\partial \Psi}{\partial x},
\end{array}\right. \\
& \left\{\begin{array}{l}
\hat{x z}=2 \mu \frac{\partial^{2} \phi}{\partial x \partial z}-\rho p^{2} \Psi-2 \mu \frac{\partial^{2} \Psi}{\partial x^{2}}, \\
\overparen{z z}=-\rho p^{2} \phi-2 \mu \frac{\partial^{2} \phi}{\partial x^{2}}-2 \mu \frac{\partial^{2} \Psi}{\partial x \partial z},
\end{array}\right.
\end{aligned}
$$



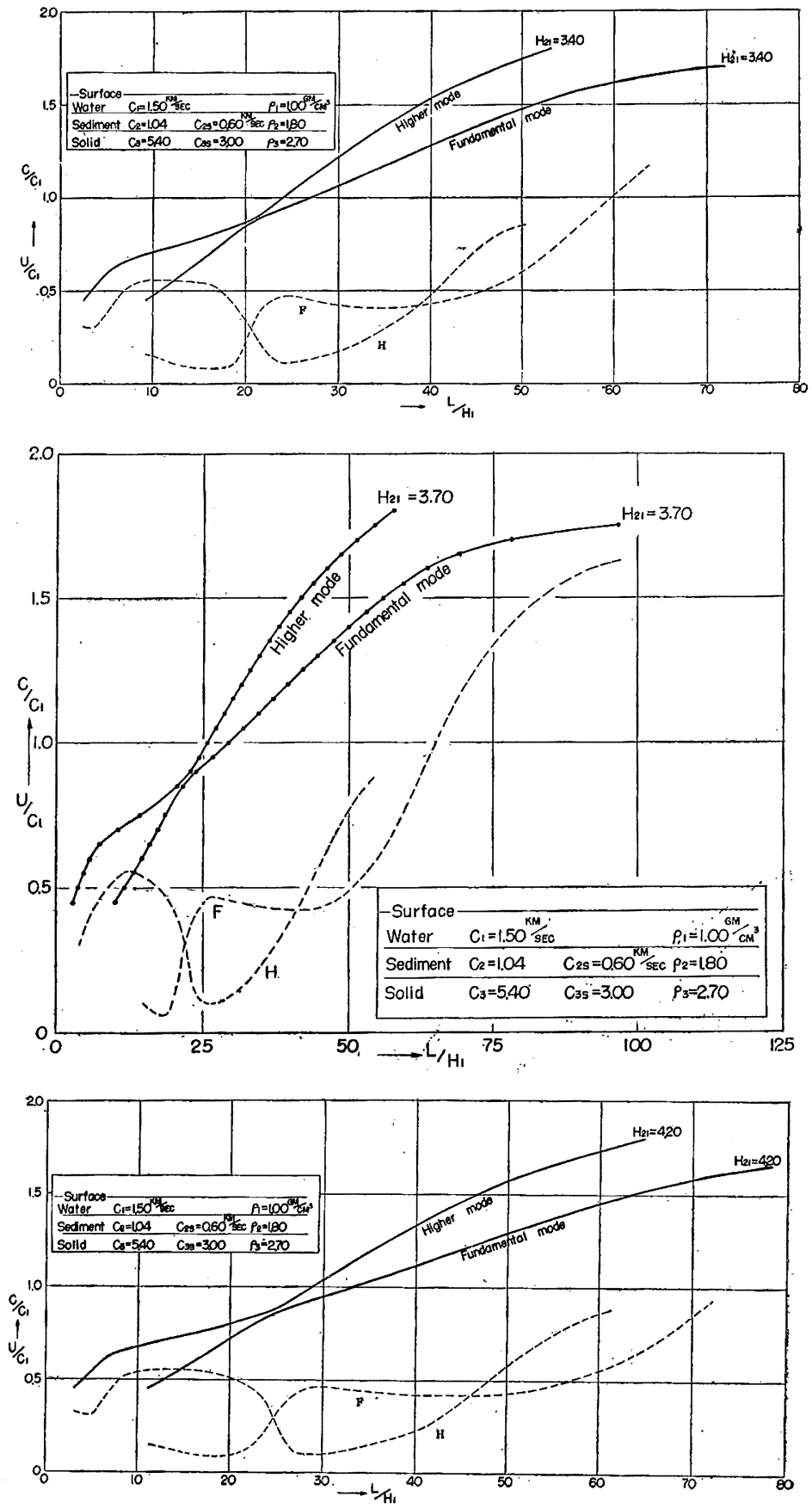

Fig. 25. Theoretical phase and group velocity of Rayleigh waves for the case of [liquid-solid-solid] structure when $\mathrm{H}_{2} / \mathrm{H}_{1}$ $=3.40,3.70$ and 4.20 . (See Table 14) Group velocity was obtained by numerically differentiating the phase velocity. 
the relation between the velocity and the period can be deduced through calculations which would satisfy the conditions at the respective boundaries. Calculations were done by the IBM 704 electronic computer.

\section{Agreement of experimental data with theoretical curves}

Trying the computation for several cases of the structure, the writer has obtained a result shown in Fig. 25 and Table 14, which explains the observation data of the

Table 9. A model of the structure adequately explaned the observation data.

\begin{tabular}{|lllll|}
\hline & Surface & & & \\
\hline (1) & Water & $C_{1}=1.50 \mathrm{~km} / \mathrm{sec}$ & $\rho_{1}=1.00 \mathrm{gm} / \mathrm{cm}^{3}$ \\
\hline (2) Sediment & $C_{2}=1.04$ & $C_{2 s}=0.60 \mathrm{~km} / \mathrm{sec}$ & $\rho_{2}=1.80$ \\
\hline (3) Solid & $C_{3}=5.40$ & $C_{3 s}=3.00$ & $\rho_{3}=2.70$ \\
\hline & $C_{i}$ & $(i=1,2,3):$ & \\
& $C_{i s}$ & $(i=2,3):$ velocity of compressional wave \\
& $\rho_{i}, \quad(i=1,2,3):$ density of each layer & \\
& &
\end{tabular}

3rd and 4th phases. In this case, as shown in Table 9 , the velocity of compressional waves in the sedimentary layer is assumed to be smaller than that in the water layer, and the value of poisson's ratio is assumed to be 0.25 .

Referring to the Fig. 25, we can recognize that the branches of the fundamental mode and the higher mode in phase velocity approach to each other at their branch points as if two straight lines are crossing, and the curves of their group velocity intersect and present remarkable appearance of stationary states.

Then we have two striking velocities which show the existence of the 3rd phase and the 4 th phase, i.e. the relation between the group velocity $(U)$ and the period $(T)$ obtained from the above theoretical curves in Fig. 25 is shown in Fig. 26 and Table 15 with good agreement with the observed data.

\section{Examination}

In the following the writer intends to examine the variation of the above situation under the different conditions of the sedimentary layer. The same cases except in the compressional wave velocity as the above are shown in Fig. 27, in which the velocity of compressional waves in the sedimentary layer is larger than that in the water layer. As will be easily seen, Fig. 28 is much different from the above results in Figs. 25 and 27. There is no appearence of the two remarkable group velocities. For reference, when the velocity $C_{2 s}$ of distortional waves in the sedimentary layer is larger or smaller than that of the above cases, the aspects are shown in Figs. 29, 30 and 31.

After all paying attention to the nature of the sedimentary layer, assuming the velocity of compressional waves of the sedimentary layer to be smaller than that of the water layer, and letting the water layer and the 2nd layer to be adequately thick, we have a suitable result which explains the observation data. Whether or not the results of the writer's experiment represent the actual crustal structure cannot be judged at the present stage of our knowledge, but it can be said at least that the model is most favorable for the abovementioned hypothesis.

Although reports on the character of the sedimentary layer have been scanty it 


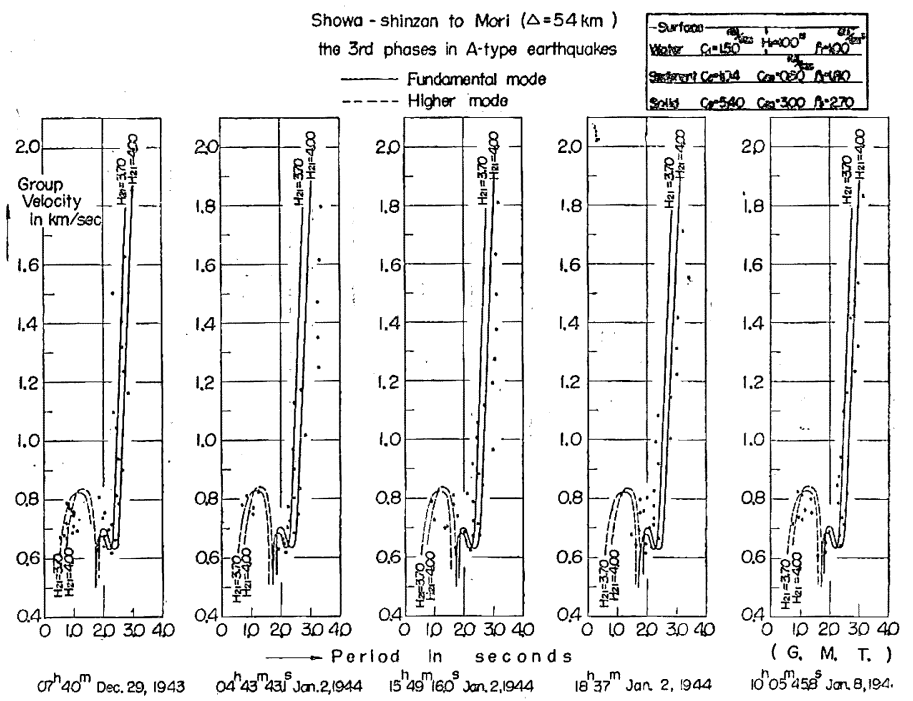

(a)

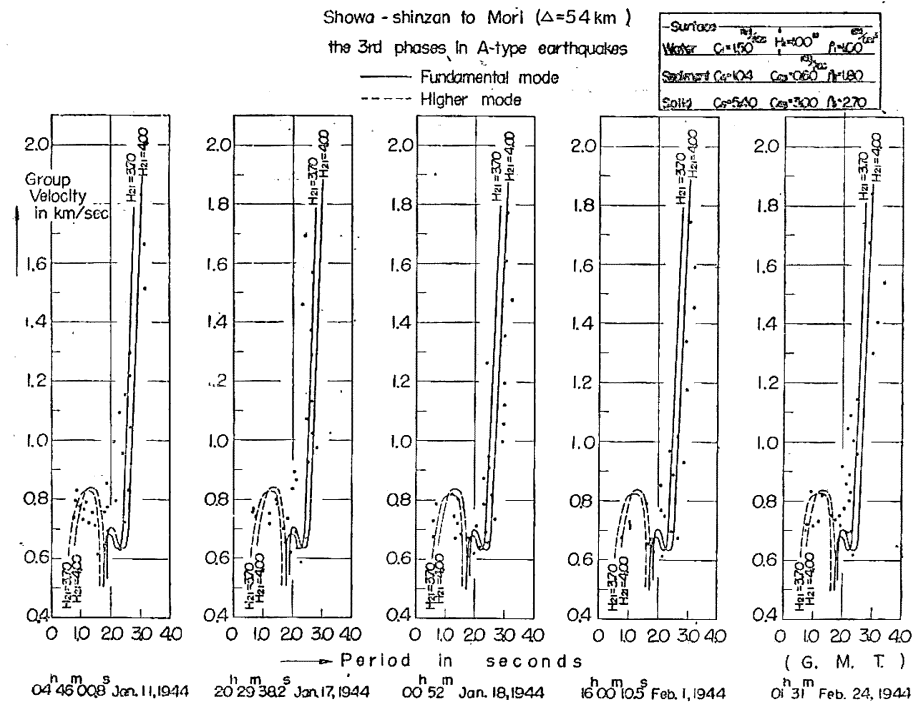

(b)

Fig. 26-(a), (b). Agreement of experimental data with theoretical curves. Observed group velocity of $3 \mathrm{rd}$ phase in A-type earthquakes compared with the theoretical Rayleigh waves dispersion.

(cf. Fig. 24-(a) and Table 13-(a)) 


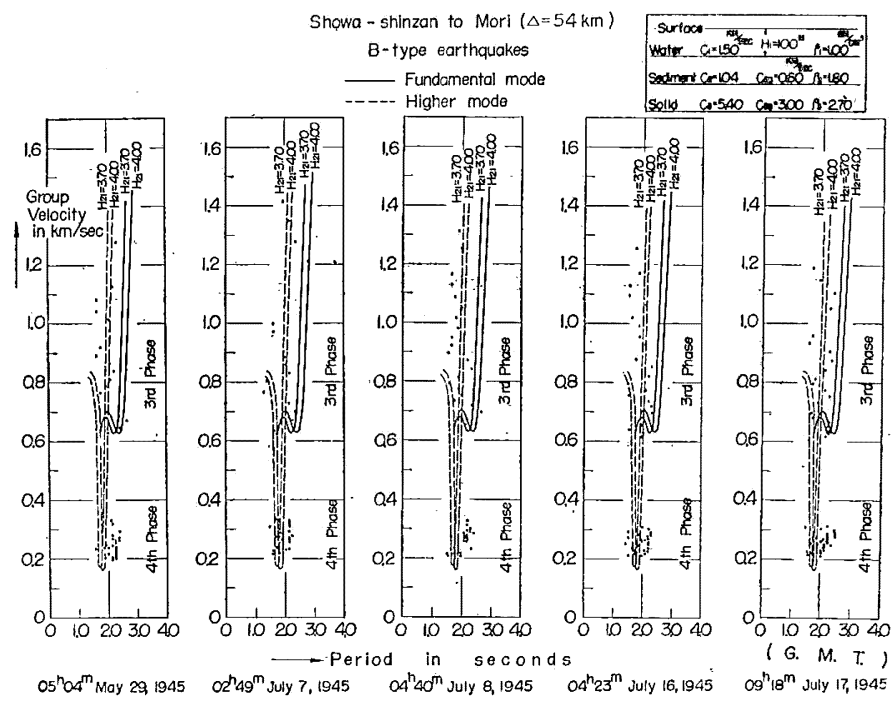

(c)

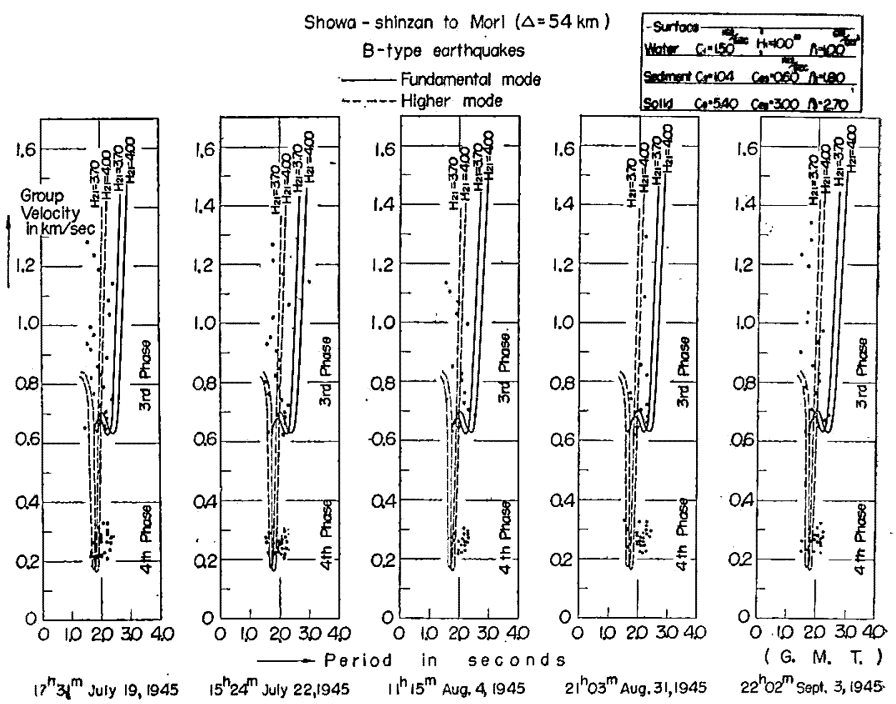

(d)

Fig. 26. Agreement of experimental data with theoretical curves. Experimental data of the 3rd and 4th phases of B-type earthquakes compared with the theoretical curves.

(cf. Fig. 24-(b) and Table 13-(b)) 


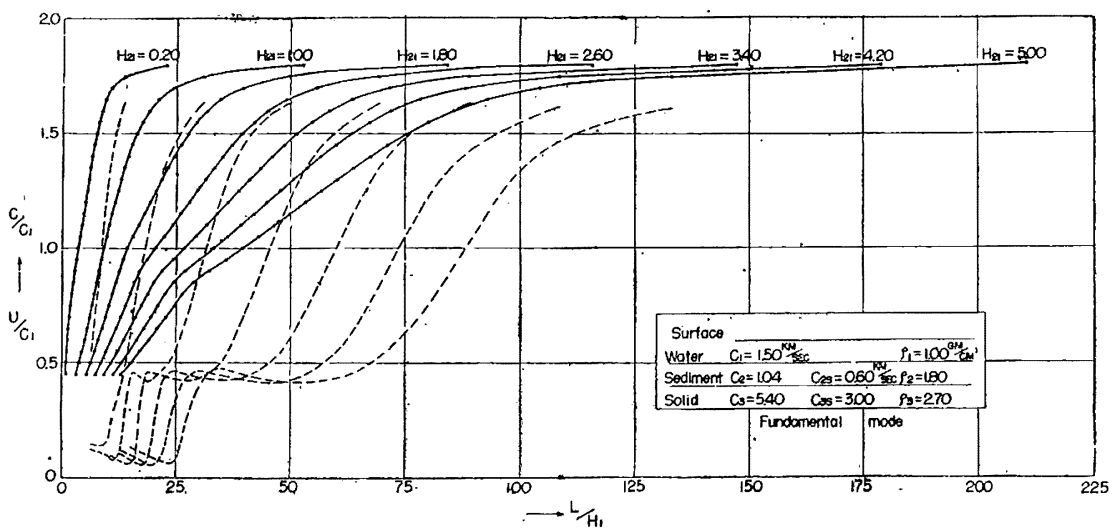

(a)

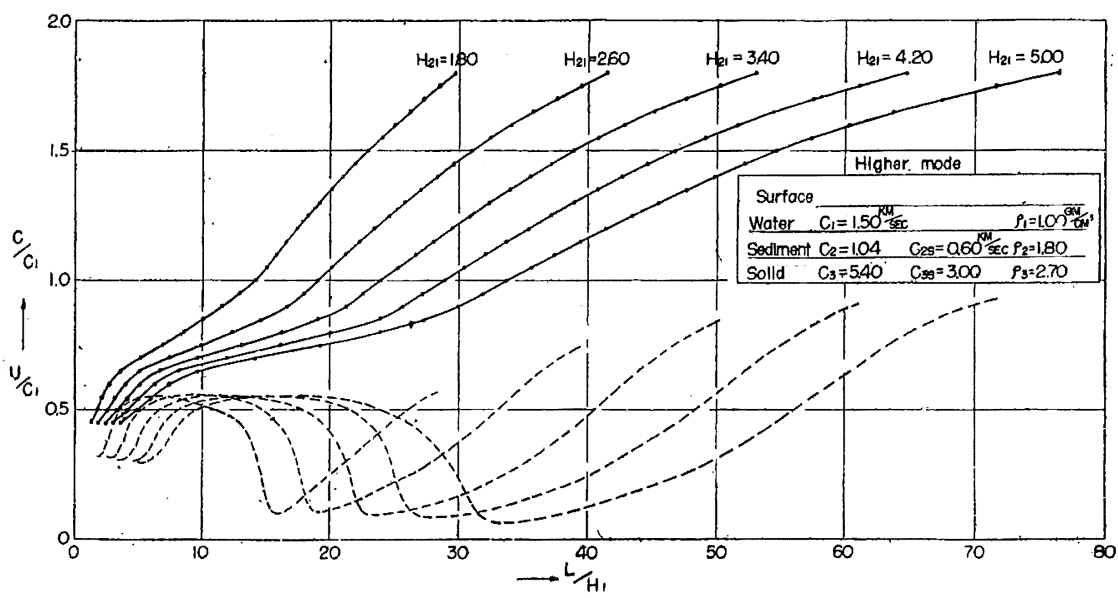

(b)

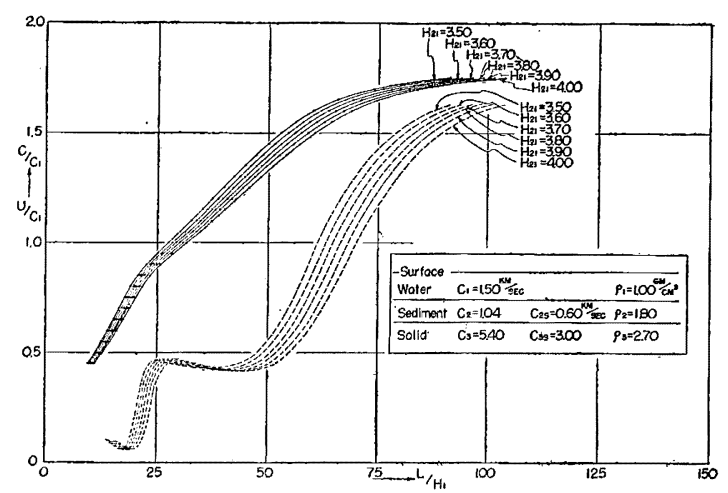

(c)

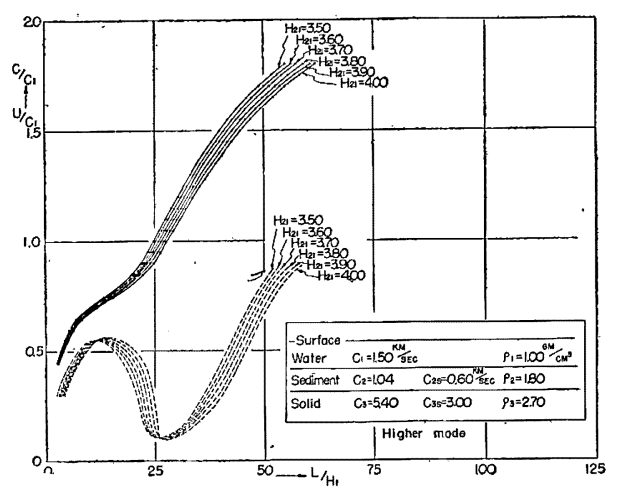

(d)

Fig. 27. Theoretical phase and group velocity of Rayleigh waves for the case of (liquid-solid-solid) structure (see Table $14 \mathrm{a}$. b). Group velocity of the Fig. 27 (a) and (b) was obtained by numerically differentiating the phase velocity. 


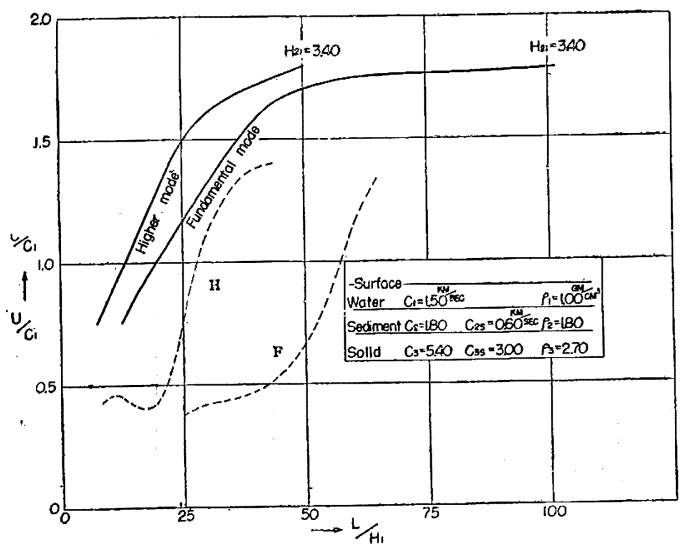

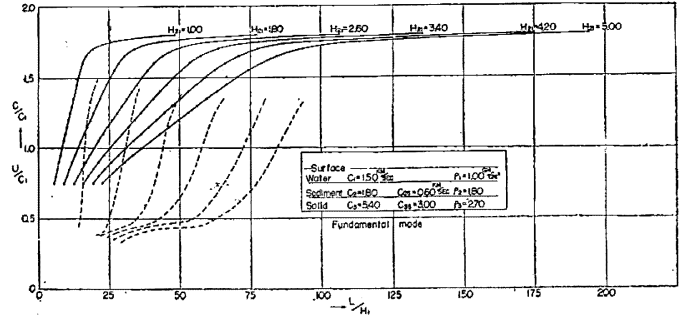

(c)

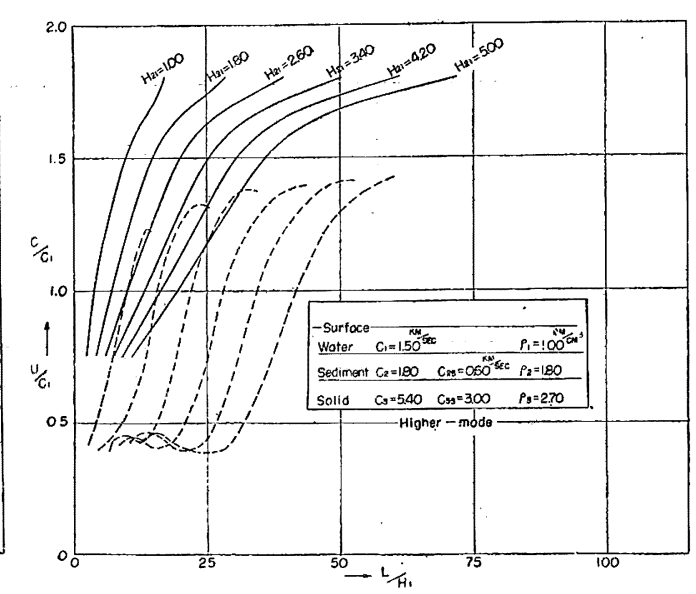

(d) (b)

$H_{21}=4.20$

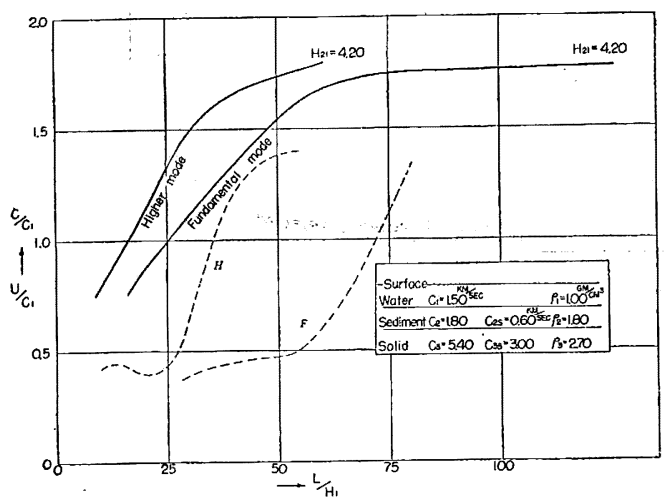

Fig. 28. This is the case appearing no such a striking plenomenon as seen in Figs. 25 and 27 , when the velocity of compressional wave in the sedimentary layer is larger than that of the water layer.

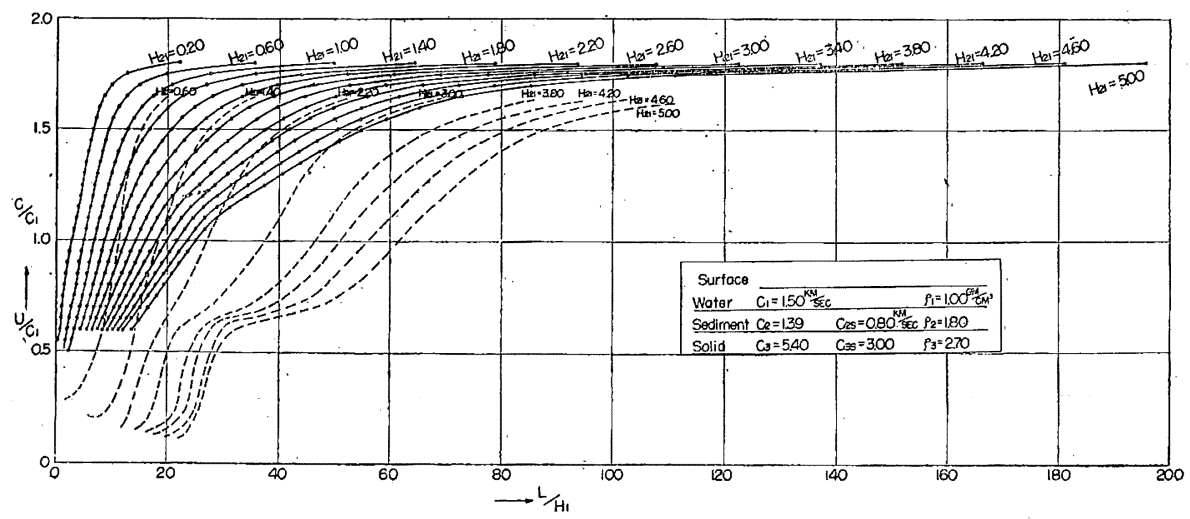

Fig. 29. Theoretical phase and group velocity of Rayleigh waves for the case of [liquid-solid-solid] structure.

Group velocity was obtained by numerically differentiating the phase velocity. 


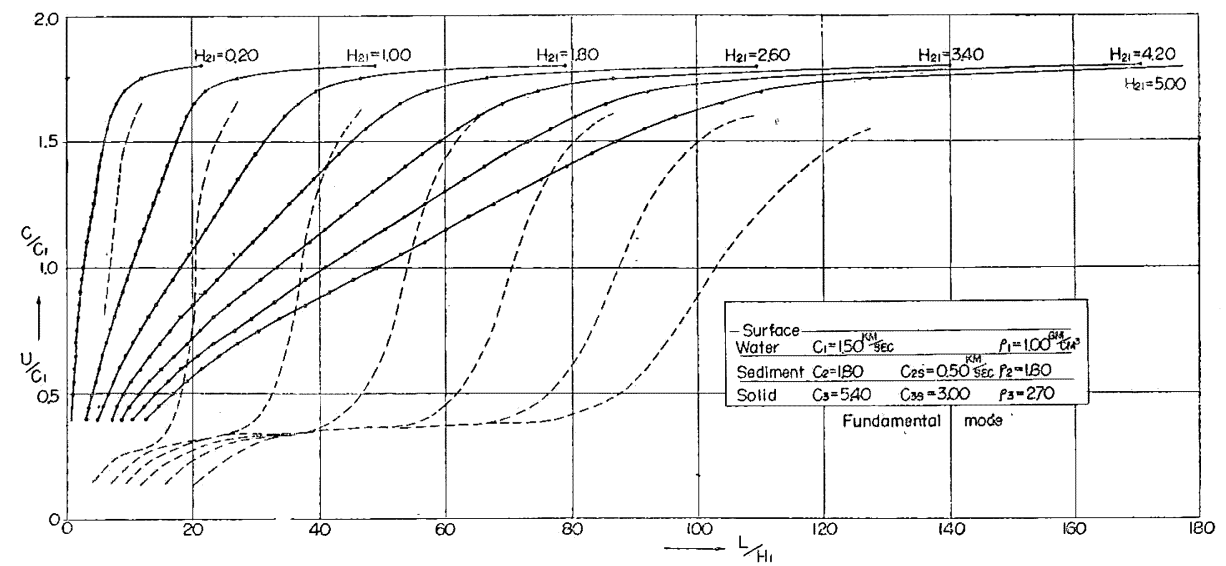

(a)

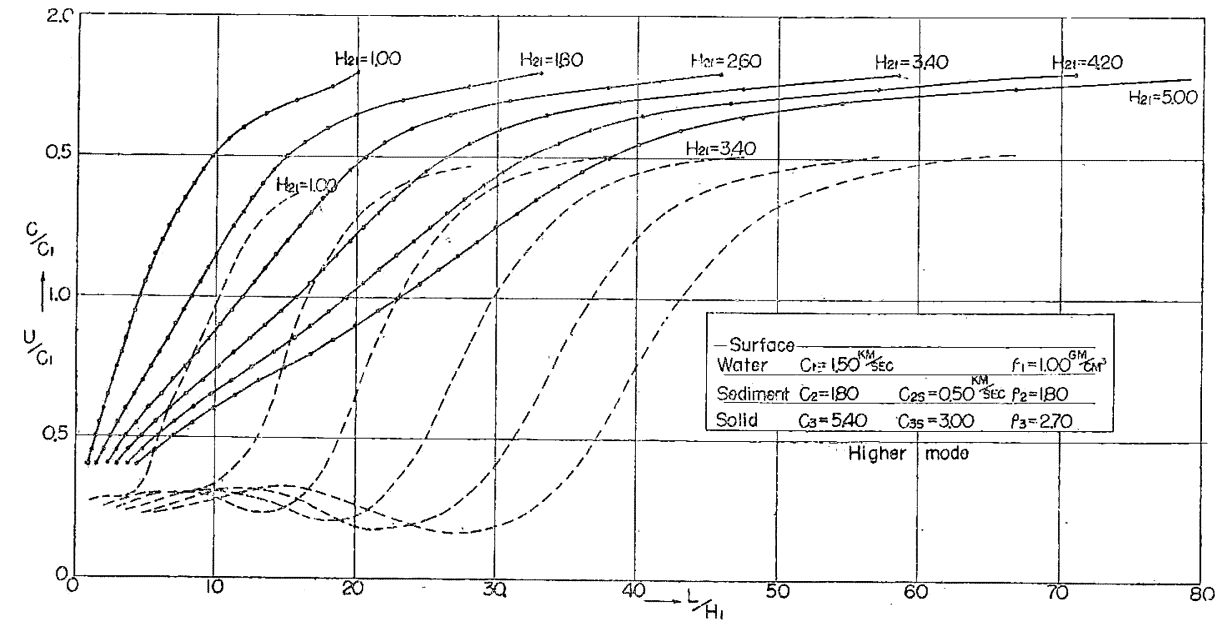

(b)

Fig. 30. Theoretical phase and group velocity of Rayleigh waves for the case of [liquid-solid-solid] structure. (see Table 17)

Group velocity was obtained by numerically differentiating the phase velocity.

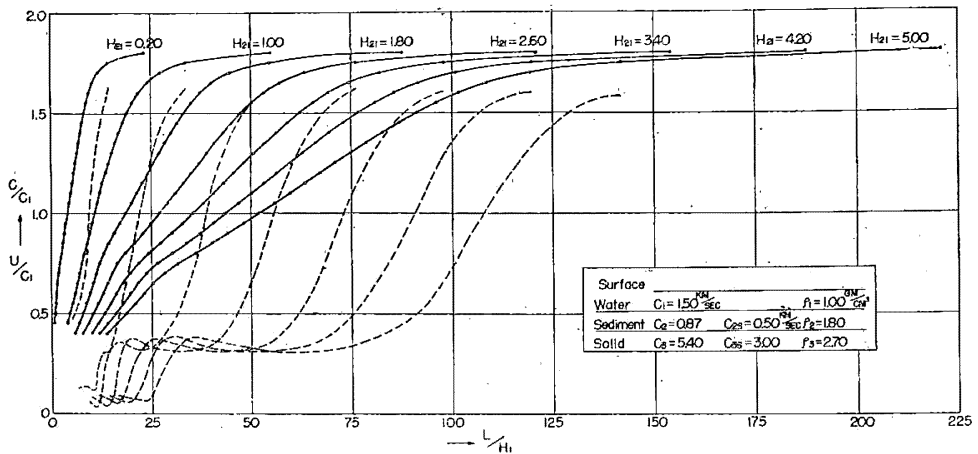

Fig. 31. Theoretical phase and group velocity of Rayleigh waves for the case of [liquid-solid-solid] structure.

Group velocity was obtained by numerically differentiating the phase velocity. 
is fully understood that the role of the layer is very important in solving the present problem. And in the future the existence of the sedimentary layer will be significant to research as on seismic waves.

The writer intends to discuss the amplitude and other factors at a future opportunity.

\section{Consideration}

The writer drew the dispersion curves of Rayleigh waves of higher mode for the same model of Figs. 25 and 27. The computation was made up to the 3rd shear mode. The results are shown in Fig. 32 and Table 16. They revealed, as was ex-

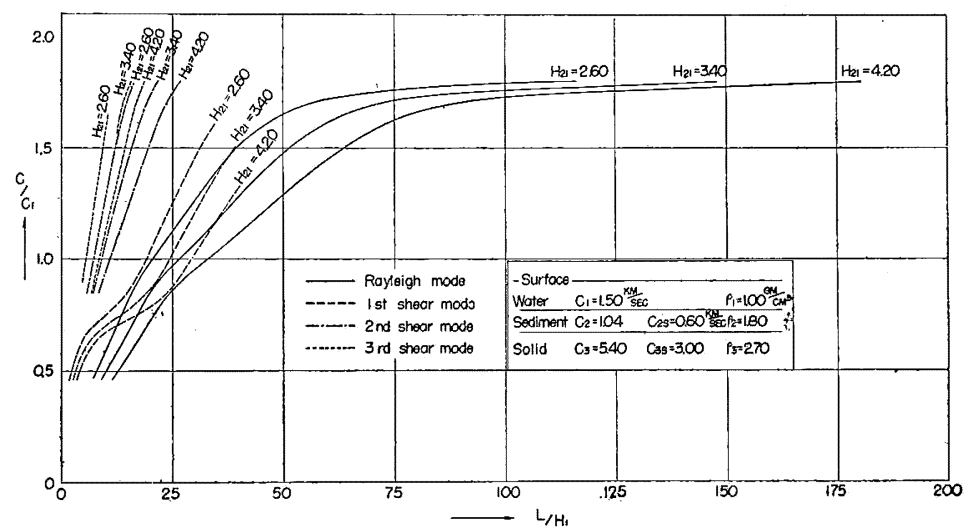

Fig. 32. Theoretical phase velocity of Rayleigh waves in the first four modes.

pected, that the 2nd and 3rd shear modes did not show such a unique phenomenon as is seen in the 1st shear mode (see Figs. 25 and 27). Thus, it can be concluded that the case illustrated in Figs. 25 and 27 is the most appropriate for the explanation of the above-mentioned phenomenon.

\section{Problems for Future Study}

-A few phases detected in the earthquakes during the Sakurajima volcanic activity-

Sakurajima in Kagoshima Prefecture, Kyushu is an active volcano. Kagoshima Local Meteorological Observatory (L.M.O.) is situated at $\Delta=10 \mathrm{~km}$ from Sakurajima across Kagoshima Bay. Hence, from the viewpoint of location, the relation between the volcano and this observatory is similar to that between Volcano Usu and Mori Observatory. The writer, in the course of the study of the seismograms of the Sakurajima volcanic activity as recorded at Kagoshima L.M.O., discovered a few phases which seem to have originated from the same cause as in the case of Volcano Usu.

Fig. 33 shows the seismogram of 1939, and Fig. 34 that of 1946 . Three phases represented by $\mathrm{a}, \mathrm{b}$ and $\mathrm{c}$ in both figures were distinctly observed in the $E-W$ component which is much stronger than that of the $N-S$ component. Throughout the whole period of the volcanic activity, in both 1939 and 1946, these phases appeared 

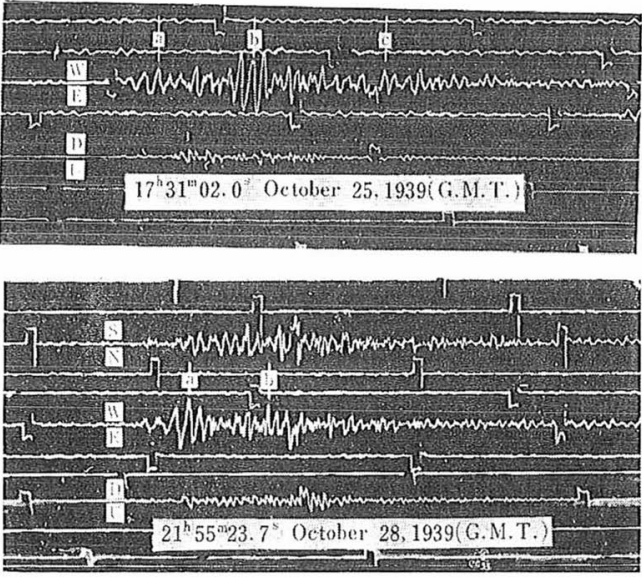

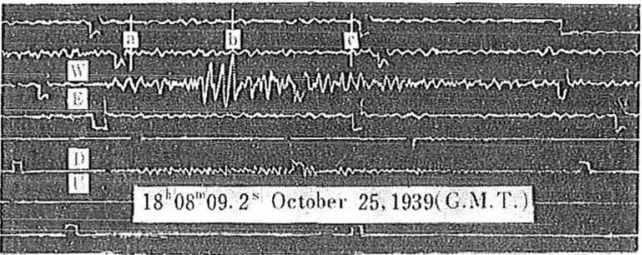

Kagoshima Local Observatory: $\varphi=31^{\circ} 34^{\prime} N$, $\lambda=130^{\circ} 33^{\prime} \mathrm{E}, H=4.4 \mathrm{~m}$ (a.s.l.)

Kagoshima Wiechert seismograph

Magnification: $V_{N}=58, V_{E}=52$

Period: $T_{0 N}=4.6 \mathrm{sec}, T_{0 E}=4.6 \mathrm{sec}$. Interval of time check marks is one minute.

Fig. 33. Seismograms of the earthquakes in relation to Sakurajima volcanic activity in 1939, recorded at Kagoshima L.M.O., showing new phases $\mathrm{a}, \mathrm{b}$ and $\mathrm{c}$.
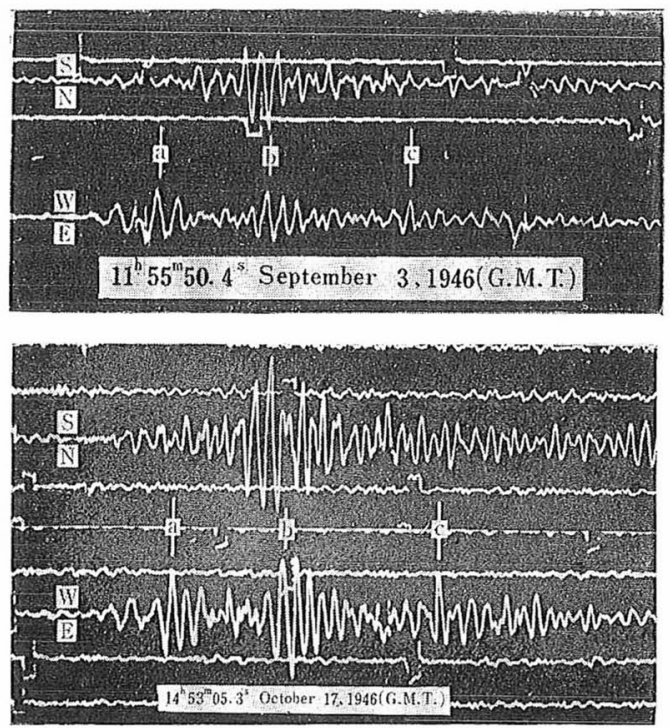

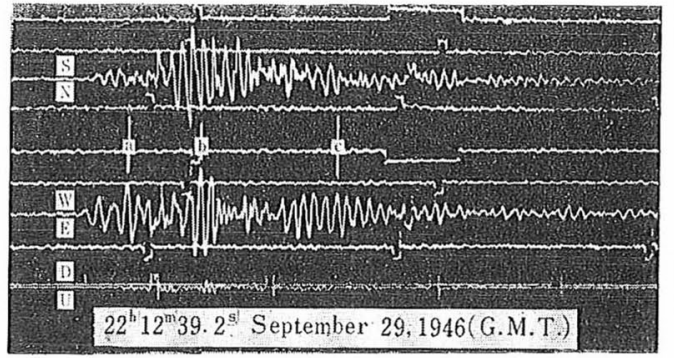

Kagoshima Wiechert seismograph Magnification: $V_{N}=90, V_{E}=70$ Period: $\quad T_{0 N}=3.7 \mathrm{sec}, T_{0 E}=4.5 \mathrm{sec}$. Interval of time check marks is one minute.

Fig. 34. Seismograms of the earthquakes in relation to Sakurajima volcanic activity in 1946, recorded at Kagoshima L.M.O., showing new phases $\mathrm{a}, \mathrm{b}$ and $\mathrm{c}$. 
with an 1dentical lapse of time after the time of arrival of P. Time deviation is noticed between the phases in $N-S$ component and those in $E-W$ component. It is also noticeable that the amplitude of each phase greatly differs between the two groups. These phases are interesting because they involve some factors that may be related to the mechanism of volcanic activity. The writer is now calculating the dispersion curves of the Rayleigh waves and the Love waves by using the IBM 704 electronic computer.

\section{Supplement}

With the help of the IBM 704 electronic computer, the dispersion curves of the Rayleigh waves can be drawn for oceanic models in general in the same way as for the "liquid-solid-solid" case.

As a preliminary step of the study of oceanic paths, the writer has been observing the Rayleigh waves propagating through the Pacific Ocean (T. KIzAwA, 1941). Comparison of the observation data with the results of the calculation gives the curves bearing a close resemblance as shown in Figs. 35-a,b (see also Tables 18-a and $18-\mathrm{b})$.

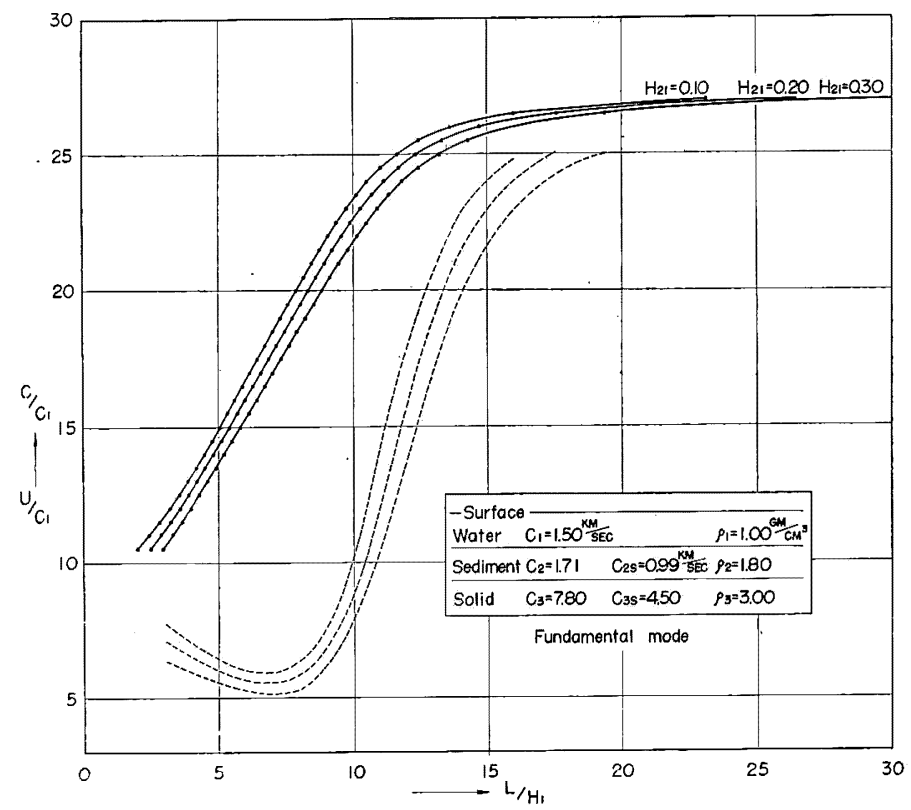

Fig. 35-a. Theoretical phase and group velocity of Rayleigh waves for oceanic path. Group velocity was obtained by numerically differentiating the phase velocity.

This problem has been studied by many researchers such as B. Gutenberg, C.F. Richter, W.S. Jardetzky and F. Press. According to their reports, the form of longperiod dispersion curves does not vary greatly with the number of crustal layers, so that most of the observed values can be explained by the curves. In the great earthquake of Chile (T. KIZAWA, 1941), the period range was between $25 \mathrm{sec}$ and 48 sec. Hence, if the thickness of the water layer of the Pacific Ocean is $4.5 \mathrm{~km}$, the 


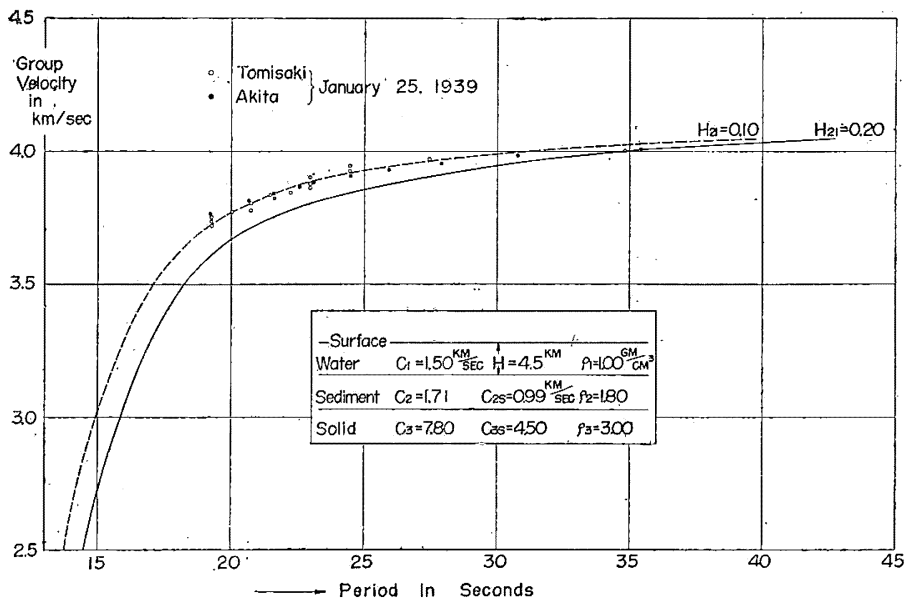

Fig. 35-b. Agreement of experimental data with theoretical curves. Observed group velocity of Rayleigh waves for oceanic path from Chile to Japan compared with theoretical curves for the case. when $H_{1}=4.5 \mathrm{~km}$.

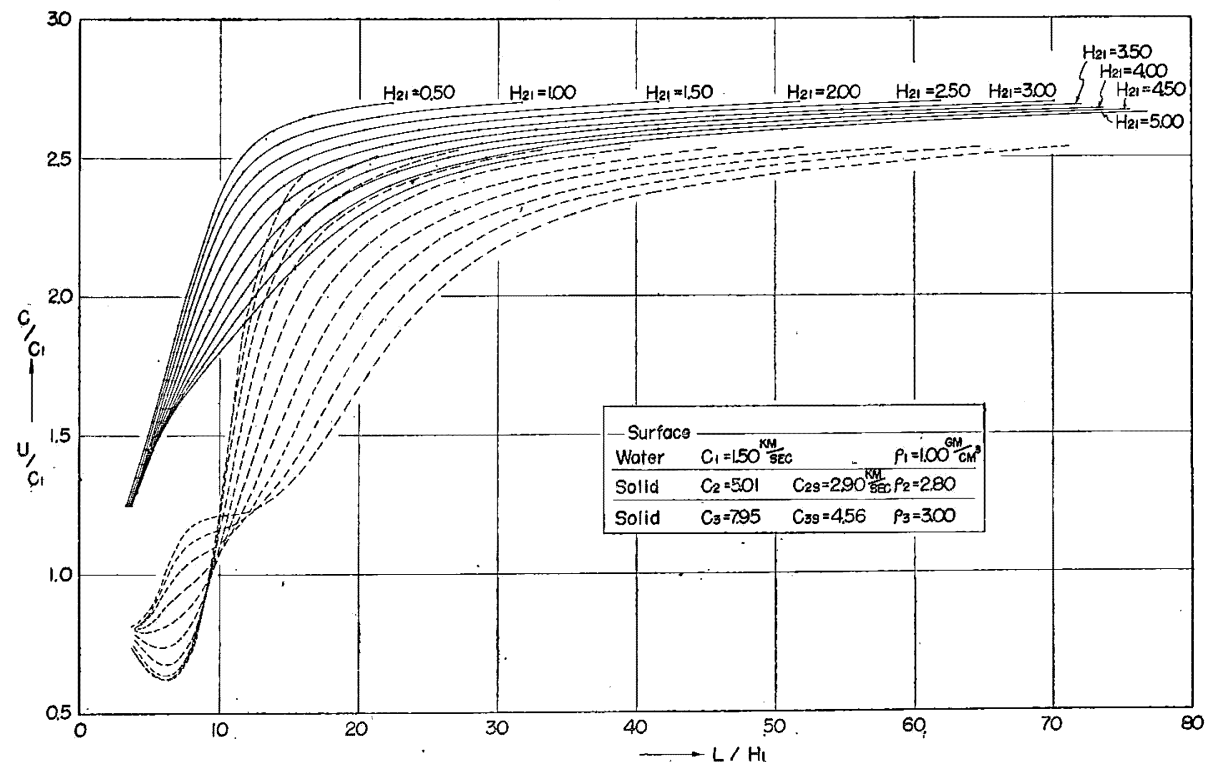

Fig. 36. Theoretical phase and group velocity of Rayleigh waves for oceanic path.

resultant curve will easily explain this, as Fig. 35-b shows.

A case of smaller period is another interesting problem (Fig. 36). Assuming the second layer to be a solid layer and the velocity of its compressional wave to be $C_{2}=5.0$ $\mathrm{km} / \mathrm{sec}$, and using the ratio of thickness $H_{2} / H_{1}(=0.5 \sim 5.0)$ as a parameter, the writer found that the curves of the group velocity show intricate variations as the value of $H_{2} / H_{1}$ 
Table 10

Theoretical phase velocity of Rayleigh waves for the case of [liquid-liquid-solid] structure (a) Fundamental mode

When : $\rho_{2} / \rho_{1}=1.50 \quad \rho_{3} / \rho_{1}=2.70 \quad \mathrm{C}_{2} / \mathrm{C}_{1}=0.53 \quad \mathrm{C}_{3} / \mathrm{C}_{1}=3.60 \quad \mathrm{C}_{3} / \mathrm{C}_{1}=2.00$

\begin{tabular}{|c|c|c|c|c|c|c|c|}
\hline $\mathrm{C} / \mathrm{C}_{1}$ & $\mathrm{~L} / \mathrm{H}_{1}$ & $\mathrm{C} / \mathrm{C}_{1}$ & $\mathrm{~L} / \mathrm{H}_{1}$ & $\mathrm{C} / \mathrm{C}_{1}$ & $\mathrm{~L} / \mathrm{H}_{1}$ & $\mathrm{C} / \mathrm{C}_{1}$ & $\mathrm{~L} / \mathrm{H}_{1}$ \\
\hline \multicolumn{2}{|c|}{$\mathrm{H}_{2} / \mathrm{H}_{1}=0.20$} & 1.75 & 44.855 & \multirow{2}{*}{$\begin{array}{l}1.60 \\
1.55 \\
1.50\end{array}$} & \multirow{2}{*}{$\begin{array}{l}54.050 \\
50.866 \\
48.127\end{array}$} & \multirow{18}{*}{$\begin{array}{l}1.45 \\
1.40 \\
1.35 \\
1.30 \\
1.25 \\
1.20 \\
1.15 \\
1.10 \\
1.05 \\
1.00 \\
0.95 \\
0.90 \\
0.85 \\
0.80 \\
0.75 \\
0.70 \\
0.65 \\
0.60 \\
0.55\end{array}$} & \multirow{2}{*}{$\begin{array}{l}63.694 \\
60.476 \\
57.439\end{array}$} \\
\hline 1.80 & 21.973 & $\begin{array}{l}1.70 \\
1.65\end{array}$ & $\begin{array}{l}38.500 \\
35.041\end{array}$ & & & & \\
\hline 1.75 & 14.509 & $\begin{array}{l}1.65 \\
1.60\end{array}$ & $\begin{array}{l}35.041 \\
32.620\end{array}$ & $\begin{array}{l}1.50 \\
1.45\end{array}$ & 45.659 & & 54.496 \\
\hline 1.70 & 12.176 & 1.55 & 30.694 & 1.40 & 43.352 & & 51.642 \\
\hline 1.65 & 10.918 & $\begin{array}{l}1.55 \\
1.50\end{array}$ & $\begin{array}{l}30.094 \\
29.029\end{array}$ & $\begin{array}{l}1.40 \\
1.35\end{array}$ & 41.167 & & 48.830 \\
\hline 1.60 & 10.049 & 1.45 & 27.529 & 1.30 & 39.061 & & 46.059 \\
\hline 1.55 & 9.362 & 1.40 & 26.131 & 1.25 & 37.006 & & 43.308 \\
\hline 1.50 & 8.773 & $\begin{array}{l}1.40 \\
1.35\end{array}$ & 24.806 & 1.20 & 34.993 & & 40.564 \\
\hline 1.45 & 8.243 & 1.30 & 23.527 & 1.15 & 33.005 & & 37.810 \\
\hline 1. 40 & 7.749 & 1.25 & 22.281 & 1.10 & 31.031 & & 35.036 \\
\hline 1.35 & 7.280 & 1.20 & 21.059 & 1.05 & 29.058 & & 32.224 \\
\hline 1. 30 & 6.826 & 1.15 & 19.852 & 1.00 & 27.083 & & 29.353 \\
\hline 1.25 & 6.381 & 1.10 & 18.652 & 0.95 & 25.089 & & 26.394 \\
\hline 1.20 & 5.941 & 1.05 & 17.455 & 0.90 & 23.070 & & 23.306 \\
\hline 1. 15 & 5. 502 & 1.00 & 16.253 & 0.85 & 21.006 & & 20.024 \\
\hline 1.10 & 5.060 & 0.95 & 15.041 & 0.80 & 18.879 & & 16.414 \\
\hline 1.05 & 4. 612 & 0.90 & 13.810 & 0.75 & 16.659 & & 12.180 \\
\hline 1.00 & 4.154 & 0.85 & 12.552 & 0.70 & 14.296 & & 6.070 \\
\hline \multirow{7}{*}{$\begin{array}{l}0.95 \\
0.90 \\
0.85 \\
0.80 \\
0.75 \\
0.70 \\
0.65 \\
0.60 \\
0.55\end{array}$} & \multirow{7}{*}{$\begin{array}{l}3.683 \\
3.196 \\
2.692 \\
2.183 \\
1.700 \\
1.276 \\
0.915 \\
0.594 \\
0.254\end{array}$} & $\begin{array}{l}0.80 \\
0.75\end{array}$ & $\begin{array}{r}11.253 \\
9.894\end{array}$ & \multirow{2}{*}{$\begin{array}{l}0.65 \\
0.60 \\
0.55\end{array}$} & \multirow{2}{*}{$\begin{array}{r}11.696 \\
8.640 \\
4.222\end{array}$} & \multicolumn{2}{|c|}{$\mathrm{H}_{2} / \mathrm{H}_{1}=5.80$} \\
\hline & & 0.70 & 8.444 & & & \multirow{8}{*}{$\begin{array}{l}1.80 \\
1.75 \\
1.70 \\
1.65 \\
1.60 \\
1.55 \\
1.50 \\
1.45 \\
1.40 \\
1.35\end{array}$} & \multirow{6}{*}{$\begin{array}{r}171.401 \\
118.027 \\
101.422 \\
92.359 \\
86.030 \\
80.994 \\
76.629\end{array}$} \\
\hline & & 0.65 & 6.842 & \multirow{2}{*}{\multicolumn{2}{|c|}{$\mathrm{H}_{2} / \mathrm{H}_{1}=4.20$}} & & \\
\hline & & 0.60 & 4. 952 & & & & \\
\hline & & 0.55 & 2.281 & \multirow{24}{*}{$\begin{array}{l}1.80 \\
1.75 \\
1.70 \\
1.65 \\
1.60 \\
1.55 \\
1.50 \\
1.45 \\
1.40 \\
1.35 \\
1.30 \\
1.25 \\
1.20 \\
1.15 \\
1.10 \\
1.05 \\
1.00 \\
0.95 \\
0.90 \\
0.85 \\
0.80 \\
0.75 \\
0.70 \\
0.65 \\
0.60 \\
0.55\end{array}$} & 128.969 & & \\
\hline & & \multicolumn{2}{|c|}{$\mathrm{H}_{2} / \mathrm{H}_{1}=2.60$} & & $\begin{array}{l}88.790 \\
76.288\end{array}$ & & \\
\hline & & \multirow{24}{*}{$\begin{array}{l}1.80 \\
1.75 \\
1.70 \\
1.65 \\
1.60 \\
1.55 \\
1.50 \\
1.45 \\
1.40 \\
1.35 \\
1.30 \\
1.25 \\
1.20 \\
1.15 \\
1.10 \\
1.05 \\
1.00 \\
0.95 \\
0.90 \\
0.85 \\
0.80 \\
0.75 \\
0.70 \\
0.65 \\
0.60 \\
0.55\end{array}$} & \multirow{3}{*}{$\begin{array}{l}86.492 \\
59.539 \\
51.129 \\
46.551\end{array}$} & & $\begin{array}{l}69.472 \\
69.470\end{array}$ & & \\
\hline \multicolumn{2}{|c|}{$\mathrm{H}_{2} / \mathrm{H}_{1}=1.00$} & & & & 64.720 & & $\begin{array}{l}72.690 \\
69.043\end{array}$ \\
\hline 1.80 & 43.891 & & & & $\begin{array}{l}60.920 \\
57.632\end{array}$ & & 65.560 \\
\hline 1.75 & 30.049 & & $\begin{array}{l}40.551 \\
43.359\end{array}$ & & 54.681 & 1.30 & 62.201 \\
\hline 1.70 & 25.732 & & 40.802 & & 51.923 & 1.25 & 58.939 \\
\hline 1.65 & 23.382 & & 38.604 & & 49.307 & 1.20 & 55.747 \\
\hline 1.60 & 21.742 & & 36.616 & & 46.779 & 1.15 & 52.581 \\
\hline 1.55 & 20.437 & & 34.766 & & 44.330 & 1.10 & 49.439 \\
\hline 1.50 & 19.313 & & 33.009 & & 41.918 & 1.05 & 46.308 \\
\hline 1.45 & 18.297 & & 31.314 & & 39.535 & 1.00 & 43.170 \\
\hline 1.40 & 17.353 & & 29.668 & & 37.177 & 0.95 & 40.002 \\
\hline 1.35 & 16.456 & & 28.048 & & 34.818 & 0.90 & 36.794 \\
\hline 1.30 & 15.592 & & 26.451 & & 32.451 & 0.85 & 33.516 \\
\hline 1.25 & 14.750 & & 24.864 & & 30.070 & 0.80 & 30.141 \\
\hline 1.20 & 13.923 & & 23.280 & & 27.653 & 0.75 & 26.618 \\
\hline 1.15 & 13.106 & & 21.691 & & 25.185 & 0.70 & 22.873 \\
\hline 1.10 & 12.292 & & 20.089 & & 22.641 & 0.65 & 18.758 \\
\hline 1.05 & 11.480 & & 18.465 & & 19.989 & 0.60 & 13.932 \\
\hline 1.00 & 10.663 & & 16.804 & & 17.167 & 0.55 & 6.976 \\
\hline 0.95 & 9.838 & & 15.093 & & 14.062 & & \\
\hline 0.90 & 8.999 & & 13.306 & & 10.418 & & \\
\hline 0.85 & 8.137 & & 11.400 & & 5.154 & & \\
\hline $\begin{array}{l}0.80 \\
0.75\end{array}$ & $\begin{array}{l}7.246 \\
6.309\end{array}$ & & $\begin{array}{l}9.302 \\
6.830\end{array}$ & $\mathrm{H}_{2} /$ & $=5.00$ & & \\
\hline 0.70 & 5.305 & & 3.266 & 1.80 & 150.195 & & \\
\hline $\begin{array}{l}0.65 \\
0.60\end{array}$ & $\begin{array}{l}4.196 \\
2.911\end{array}$ & $\mathrm{H}_{2} /$ & 3.40 & 1.75 & 103.419 & & \\
\hline 0.55 & 1. 271 & 1.80 & 107.749 & $\begin{array}{l}1.70 \\
1.65\end{array}$ & $\begin{array}{l}88.851 \\
80.917\end{array}$ & & \\
\hline $\mathrm{H}_{2} /$ & 80 & 1.75 & 74. 177 & 1.60 & 75.372 & & \\
\hline 1.80 & 65.245 & 1.65 & 58.022 & $\begin{array}{l}1.00 \\
1.50\end{array}$ & 67.134 & & \\
\hline
\end{tabular}


(b) Higher mode

When: $\rho_{2} / \rho_{\perp}=1.50 \quad \rho_{3} / \rho_{1}=2.70 \quad \mathrm{C}_{2} / \mathrm{C}_{1}=0.53 \quad \mathrm{C}_{3} / \mathrm{C}_{1}=3.60 \quad \mathrm{C}_{3 S} / \mathrm{C}_{1}=2.00$

\begin{tabular}{|c|c|c|c|c|c|c|c|}
\hline $\mathrm{C} / \mathrm{C}_{1}$ & $\mathrm{~L} / \mathrm{H}_{1}$ & $\mathrm{C} / \mathrm{C}_{1}$ & $\mathrm{~L} / \mathrm{H}_{1}$ & $\mathrm{C} / \mathrm{C}_{1}$ & $\mathrm{~L} / \mathrm{H}_{1}$ & $\mathrm{C} / \mathrm{C}_{1}$ & $\mathrm{~L} / \mathrm{H}_{1}$ \\
\hline \multicolumn{2}{|c|}{$\mathrm{H}_{2} / \mathrm{H}_{1}=0.20$} & 1.75 & 10.987 & 1.60 & 15.919 & \multirow{18}{*}{$\begin{array}{l}1.45 \\
1.40 \\
1.35 \\
1.30 \\
1.25 \\
1.20 \\
1.15 \\
1.10 \\
1.05 \\
1.00 \\
0.95 \\
0.90 \\
0.85 \\
0.80 \\
0.75 \\
0.70 \\
0.65 \\
0.60 \\
0.55\end{array}$} & \multirow{2}{*}{$\begin{array}{l}19.643 \\
18.790\end{array}$} \\
\hline \multirow{23}{*}{$\begin{array}{l}1.80 \\
1.75 \\
1.70 \\
1.65 \\
1.60 \\
1.55 \\
1.50 \\
1.45 \\
1.40 \\
1.35 \\
1.30 \\
1.25 \\
1.20 \\
1.15 \\
1.10 \\
1.05 \\
1.00 \\
0.95 \\
0.90 \\
0.85 \\
0.80 \\
0.75 \\
0.70 \\
0.65 \\
0.60 \\
0.55\end{array}$} & \multirow{23}{*}{$\begin{array}{l}3.337 \\
3.022 \\
2.830 \\
2.675 \\
2.534 \\
2.398 \\
2.265 \\
2.132 \\
1.997 \\
1.859 \\
1.715 \\
1.564 \\
1.403 \\
1.225 \\
1.024 \\
0.796 \\
0.631 \\
0.548 \\
0.485 \\
0.428 \\
0.374 \\
0.321 \\
0.268 \\
0.213 \\
0.153 \\
0.072\end{array}$} & $\begin{array}{l}1.70 \\
1.65\end{array}$ & $\begin{array}{r}10.276 \\
9.750\end{array}$ & $\begin{array}{l}1.55 \\
1.50\end{array}$ & $\begin{array}{l}15.238 \\
14.590\end{array}$ & & \\
\hline & & $\begin{array}{l}1.05 \\
1.60\end{array}$ & 9.302 & $\begin{array}{l}1.00 \\
1.45\end{array}$ & $\begin{array}{l}14.590 \\
13.966\end{array}$ & & $\begin{array}{l}17.948 \\
17.112\end{array}$ \\
\hline & & 1.55 & 8.892 & 1.40 & 13.354 & & 16.280 \\
\hline & & 1.50 & 8.504 & 1.35 & 12.751 & & 15.447 \\
\hline & & 1.45 & 8.129 & 1.30 & 12.152 & & 14.611 \\
\hline & & 1.40 & 7.762 & 1.25 & 11.555 & & 13.771 \\
\hline & & 1.35 & 7.399 & 1.20 & 10.958 & & 12.924 \\
\hline & & 1.30 & 7.039 & 1.15 & 10.359 & & 12.064 \\
\hline & & 1.25 & 6.680 & 1.10 & 9.756 & & 11.191 \\
\hline & & 1.20 & 6.321 & 1.05 & 9.148 & & 10.300 \\
\hline & & 1.15 & 5.960 & 1.00 & 8.531 & & 9.382 \\
\hline & & 1.10 & 5.596 & 0.95 & 7.903 & & 8.430 \\
\hline & & 1.05 & 5.229 & 0.90 & 7.262 & & 7.430 \\
\hline & & 1.00 & 4.856 & 0.85 & 6.602 & & 6.360 \\
\hline & & 0.95 & 4. 477 & 0.80 & 5.917 & & 5. 176 \\
\hline & & 0.90 & 4.089 & 0.75 & 5.197 & & 3.783 \\
\hline & & 0.85 & 3. 692 & 0.70 & 4. 427 & & 1.804 \\
\hline & & $\begin{array}{l}0.80 \\
0.75\end{array}$ & $\begin{array}{l}3.281 \\
2.853\end{array}$ & \multirow{2}{*}{$\begin{array}{l}0.65 \\
0.60 \\
0.55\end{array}$} & \multirow{2}{*}{$\begin{array}{l}3.579 \\
2.592 \\
1.227\end{array}$} & \multicolumn{2}{|c|}{$\mathrm{H}_{2} / \mathrm{H}_{1}=5.80$} \\
\hline & & 0.70 & 2.403 & & & \multirow{24}{*}{$\begin{array}{l}1.80 \\
1.75 \\
1.70 \\
1.65 \\
1.60 \\
1.55 \\
1.50 \\
1.45 \\
1.40 \\
1.35 \\
1.30 \\
1.25 \\
1.20 \\
1.15 \\
1.10 \\
1.05 \\
1.00 \\
0.95 \\
0.90 \\
0.85 \\
0.80 \\
0.75 \\
0.70 \\
0.65 \\
0.60 \\
0.55\end{array}$} & \multirow{7}{*}{$\begin{array}{l}33.444 \\
30.015 \\
28.147 \\
26.760 \\
25.571 \\
24.486 \\
23.455 \\
22.460 \\
21.485\end{array}$} \\
\hline & & $\begin{array}{l}0.65 \\
0.60\end{array}$ & $\begin{array}{l}1.920 \\
1.377\end{array}$ & \multicolumn{2}{|c|}{$\mathrm{H}_{2} / \mathrm{H}_{1}=4.20$} & & \\
\hline & & 0.55 & 0.649 & 80 & 25082 & & \\
\hline & & \multicolumn{2}{|c|}{$\mathrm{H}_{2} / \mathrm{H}_{1}=2.60$} & 1.75 & 22.497 & & \\
\hline & & & & 1.70 & 21. 092 & & \\
\hline \multirow{2}{*}{\multicolumn{2}{|c|}{$\mathrm{H}_{2} / \mathrm{H}_{1}=1.00$}} & $\begin{array}{l}1.80 \\
1.75\end{array}$ & $\begin{array}{l}16.628 \\
14.888\end{array}$ & 1.65 & $\begin{array}{l}20.047 \\
19.155\end{array}$ & & \\
\hline & & $\begin{array}{l}1.75 \\
1.70\end{array}$ & $\begin{array}{l}14.888 \\
13.944\end{array}$ & $\begin{array}{l}1.60 \\
1.55\end{array}$ & $\begin{array}{l}19.155 \\
18.337\end{array}$ & & \\
\hline 1.80 & 7.802 & 1.65 & 13.244 & $\begin{array}{l}1.50 \\
1.50\end{array}$ & 17.564 & & $\begin{array}{l}21.485 \\
20.524\end{array}$ \\
\hline 1.75 & 6.929 & 1.60 & 12.647 & 1.45 & 16.815 & & 19.570 \\
\hline 1.70 & 6.459 & 1.55 & 12.100 & 1.40 & 16.082 & & 18.620 \\
\hline 1.65 & 6.113 & 1. 50 & 11.582 & 1.35 & 15.359 & & 17.670 \\
\hline 1. 60 & 5. 818 & 1.45 & 11.081 & 1.30 & 14.642 & & 16.717 \\
\hline 1.55 & 5.548 & 1.40 & 10.592 & 1.25 & 13.926 & & 15.758 \\
\hline 1.50 & 5.291 & 1.35 & 10.108 & 1.20 & 13.212 & & 14.791 \\
\hline 1.45 & 5.044 & 1.30 & 9.628 & 1.15 & 12.495 & & 13.811 \\
\hline 1.40 & 4.801 & $\begin{array}{l}1.00 \\
1.25\end{array}$ & 9.150 & 1.10 & 11.773 & & 12.815 \\
\hline 1.35 & 4.560 & 1.20 & 8.671 & 1.05 & 11.045 & & $\begin{array}{l}12.015 \\
11.798\end{array}$ \\
\hline 1.30 & 4. 321 & 1.15 & 8.191 & 1.00 & 10.307 & & 10.752 \\
\hline 1.25 & 4.083 & 1.10 & $\begin{array}{l}0.191 \\
7.707\end{array}$ & 0.95 & 9.557 & & 9.667 \\
\hline 1.20 & 3.844 & 1.05 & 7.218 & 0.90 & 8.790 & & 8.527 \\
\hline 1.15 & 3.603 & 1.00 & 6.723 & 0.85 & 8.001 & & 7.308 \\
\hline 1.10 & 3.361 & 0.95 & 6.219 & 0.80 & 7.182 & & 5.959 \\
\hline 1.05 & 3.117 & 0.90 & 5.703 & 0.75 & 6.322 & & 4. 368 \\
\hline 1.00 & 2.871 & 0.85 & 5.173 & 0.70 & 5.401 & & $\begin{array}{l}4.009 \\
2.092\end{array}$ \\
\hline 0.95 & 2. 622 & 0.80 & 4.623 & 0.65 & 4.384 & & \\
\hline 0.90 & 2.371 & 0.75 & 4.046 & 0.60 & 3. 191 & & \\
\hline 0.85 & 2.118 & 0.70 & 3.430 & 0.55 & $\begin{array}{l}0.101 \\
1.515\end{array}$ & & \\
\hline \multirow{5}{*}{$\begin{array}{l}0.80 \\
0.75 \\
0.70 \\
0.65 \\
0.60 \\
0.55\end{array}$} & \multirow{5}{*}{$\begin{array}{l}1.862 \\
1.605 \\
1.342 \\
1.068 \\
0.765 \\
0.360\end{array}$} & 0.65 & 2.758 & \multirow{2}{*}{\multicolumn{2}{|c|}{$\mathrm{H}_{2} / \mathrm{H}_{1}=5.00$}} & & \\
\hline & & \multirow{2}{*}{$\begin{array}{l}0.60 \\
0.55\end{array}$} & $\begin{array}{l}1.987 \\
0.938\end{array}$ & & & & \\
\hline & & & & 1.80 & 29.267 & & \\
\hline & & $\mathrm{H}_{2} /$ & .40 & $\begin{array}{l}1.75 \\
1.70\end{array}$ & 26.263 & & \\
\hline & & 1.80 & 20.875 & 1.65 & 23.410 & & \\
\hline $\mathrm{H}_{2} /$ & 1.80 & 1.75 & 18.712 & 1.60 & 22.370 & & \\
\hline 1.80 & 12.303 & $\begin{array}{l}1.70 \\
1.65\end{array}$ & $\begin{array}{l}17.538 \\
16.665\end{array}$ & $\begin{array}{l}1.55 \\
1.50\end{array}$ & $\begin{array}{l}21.417 \\
20.516\end{array}$ & & \\
\hline
\end{tabular}


Table 11

Theoretical phase velocity of Rayleigh waves for the case of [liquid-liquid-solid] structure when: $\rho_{2} / \rho_{1}=1.80 \quad \rho_{3} / \rho_{1}=2.70 \quad \mathrm{C}_{2} / \mathrm{C}_{1}=0.60 \quad \mathrm{C}_{3} / \mathrm{C}_{1}=3.60 \quad \mathrm{C}_{3 S} / \mathrm{C}_{1}=2.00$

\begin{tabular}{|c|c|c|c|c|c|c|c|}
\hline $\mathrm{C} / \mathrm{C}_{1}$ & $\mathrm{~L} / \mathrm{H}_{1}$ & $\mathrm{C} / \mathrm{C}_{1}$ & $\mathrm{~L} / \mathrm{H}_{1}$ & $\mathrm{C} / \mathrm{C}_{1}$ & $\mathrm{~L} / \mathrm{H}_{1}$ & $\mathrm{C} / \mathrm{C}_{1}$ & $\mathrm{~L} / \mathrm{H}_{1}$ \\
\hline \multicolumn{2}{|c|}{$\mathrm{H}_{2} / \mathrm{H}_{1}=0.20$} & \multirow{2}{*}{$\begin{array}{l}0.90 \\
0.85 \\
0.80\end{array}$} & \multirow{2}{*}{$\begin{array}{l}7.125 \\
6.310 \\
5.452\end{array}$} & \multirow{2}{*}{$\begin{array}{l}1.20 \\
1.15 \\
1.10\end{array}$} & \multirow{2}{*}{$\begin{array}{l}23.999 \\
22.506 \\
21.025\end{array}$} & \multirow{2}{*}{$\begin{array}{l}1.55 \\
1.50 \\
1.45\end{array}$} & \multirow{2}{*}{$\begin{array}{l}54.909 \\
51.518 \\
48.540\end{array}$} \\
\hline 1.80 & 21.866 & & & & & & \\
\hline 1.75 & 13. 761 & 0.75 & 4.525 & 1.05 & 19.547 & 1.40 & 45.821 \\
\hline 1.70 & 11.269 & 0.70 & 3. 491 & 1.00 & 18.062 & 1.35 & $\begin{array}{l}40.821 \\
43.268\end{array}$ \\
\hline \multirow{2}{*}{$\begin{array}{l}1.65 \\
1.60 \\
1.55\end{array}$} & \multirow{2}{*}{$\begin{array}{l}9.963 \\
9.082 \\
8.398\end{array}$} & 0.65 & 2.274 & 0.95 & 16.558 & 1.30 & 40.847 \\
\hline & & \multicolumn{2}{|c|}{$\mathrm{H}_{2} / \mathrm{H}_{1}=1.80$} & $\begin{array}{l}0.90 \\
0.85\end{array}$ & $\begin{array}{l}15.023 \\
13.438\end{array}$ & $\begin{array}{l}1.25 \\
1.20\end{array}$ & $\begin{array}{l}38.503 \\
36.219\end{array}$ \\
\hline \multirow{3}{*}{$\begin{array}{l}1.50 \\
1.45 \\
1.40\end{array}$} & \multirow{3}{*}{$\begin{array}{l}7.820 \\
7.304 \\
6.827\end{array}$} & 1.80 & 68.473 & \multirow{4}{*}{$\begin{array}{l}0.80 \\
\\
0.75 \\
0.70 \\
0.65\end{array}$} & 11.774 & 1.15 & 33.970 \\
\hline & & 1.75 & 43.384 & & 9.988 & 1,10 & 31.743 \\
\hline & & 1.70 & 35.761 & & 7.987 & 1.05 & 29.523 \\
\hline \multirow{3}{*}{$\begin{array}{l}1.35 \\
1.30 \\
1.25\end{array}$} & \multirow{3}{*}{$\begin{array}{l}6.374 . \\
5.936 \\
5.506\end{array}$} & 1.65 & 31.808 & & 5.537 & 1.00 & \multirow{4}{*}{$\begin{array}{l}25.034 \\
22.731 \\
20.354\end{array}$} \\
\hline & & 1.60 & 29.177 & \multirow{2}{*}{\multicolumn{2}{|c|}{$\mathrm{H}_{2} / \mathrm{H}_{1}=3.40$}} & \multirow{3}{*}{$\begin{array}{l}0.95 \\
0.90 \\
0.85\end{array}$} & \\
\hline & & 1.55 & 27.161 & & & & \\
\hline 1.20 & $\begin{array}{l}5.079 \\
4.651\end{array}$ & 1.50 & 25.479 & & & \\
\hline $\begin{array}{l}1.15 \\
1.10\end{array}$ & $\begin{array}{l}4.651 \\
4.217\end{array}$ & $\begin{array}{l}1.45 \\
1.40\end{array}$ & $\begin{array}{l}24.000 \\
22.647\end{array}$ & 1.75 & 72.885 & 0.80 & 17. 861 \\
\hline 1.05 & 3.772 & & & 1.70 & 60.081 & $\begin{array}{l}0.75 \\
0.70\end{array}$ & $\begin{array}{l}15.188 \\
12.202\end{array}$ \\
\hline 1.00 & 3.312 & $\begin{array}{l}1.35 \\
1.30\end{array}$ & $\begin{array}{l}21.380 \\
20.173\end{array}$ & 1.65 & 53.449 & & \\
\hline 0.95 & 2.833 & 1.25 & 19.007 & $\begin{array}{l}1.60 \\
1.55\end{array}$ & $\begin{array}{l}49.044 \\
45.663\end{array}$ & 0.65 & 8.553 \\
\hline 0.90 & 2.336 & 1.20 & 17.869 & & & $\mathrm{H}_{2} /$ & $=5.00$ \\
\hline 0.85 & 1.843 & 1.15 & 16.748 & $\begin{array}{l}1.50 \\
1.45\end{array}$ & $\begin{array}{l}42.846 \\
40.363\end{array}$ & & \\
\hline 0.80 & 1.401 & 1.10 & 15.638 & 1.40 & 38.101 & 1.80 & 161.505 \\
\hline 0.75 & 1.038 & 1.05 & 14.529 & & & 1.75 & 102. 370 \\
\hline 0.70 & 0.736 & 1.00 & 13.414 & $\begin{array}{l}1.35 \\
1.30\end{array}$ & $\begin{array}{l}35.984 \\
33.963\end{array}$ & 1.70 & 84.393 \\
\hline 0.65 & 0.458 & 0.95 & 12.284 & 1.25 & 32.013 & 1.65 & 75.075 \\
\hline $\mathrm{H}_{2} /$ & 1.00 & $\begin{array}{l}0.90 \\
0.85\end{array}$ & $\begin{array}{r}11.129 \\
9.935\end{array}$ & 1.20 & 30.112 & $\begin{array}{l}1.60 \\
1.55\end{array}$ & $\begin{array}{l}68.895 \\
64.147\end{array}$ \\
\hline 1.80 & 45.194 & 0.80 & 8.681 & $\begin{array}{l}1.15 \\
1.10\end{array}$ & $\begin{array}{l}28.243 \\
26.389\end{array}$ & 1.50 & 60.193 \\
\hline 1.75 & 28.624 & 0.75 & 7.330 & & & 1.45 & 56. 712 \\
\hline 1.70 & 23.577 & 0.70 & 5.815 & $\begin{array}{l}1.05 \\
1.00\end{array}$ & $\begin{array}{l}24.540 \\
22.683\end{array}$ & 1.40 & 53.532 \\
\hline 1.65 & 20.959 & 0.65 & 3.961 & $\begin{array}{l}1.00 \\
0.95\end{array}$ & 20.803 & 1.35 & 50.561 \\
\hline $\begin{array}{l}1.60 \\
1.55\end{array}$ & $\begin{array}{l}19.213 \\
17.875\end{array}$ & $\mathrm{H}_{2} / \mathrm{l}$ & 2.60 & 0.90 & 18.883 & $\begin{array}{l}1.30 \\
1.25\end{array}$ & $\begin{array}{l}47.725 \\
44.985\end{array}$ \\
\hline 1.50 & 16.757 & 1.80 & 91.733 & $\begin{array}{l}0.85 \\
0.80\end{array}$ & $\begin{array}{l}16.903 \\
14.826\end{array}$ & 1.20 & 42.318 \\
\hline 1.45 & 15.771 & 1.75 & 58.134 & & & 1.15 & 39.697 \\
\hline 1.40 & 14.869 & 1.70 & 47.920 & $\begin{array}{l}0.75 \\
0.70\end{array}$ & $\begin{array}{l}12.598 \\
10.106\end{array}$ & 1.10 & 37.096 \\
\hline 1.35 & 14.025 & 1.65 & 42.630 & 0.65 & 7.058 & 1.05 & 34.503 \\
\hline 1.30 & 13.217 & 1.60 & 39.115 & & & 1.00 & 31.896 \\
\hline 1.25 & 12.437 & 1.55 & 36.417 & $\mathrm{H}_{2} /$ & 20 & 0.95 & 29.261 \\
\hline 1.20 & 11.674 & 1.50 & 34.171 & & & 0.90 & 26.571 \\
\hline 1.15 & 10.922 & 1.45 & 32.190 & 1.80 & 138.253 & 0.85 & 23.796 \\
\hline 1.10 & 10.175 & 1.40 & 30.379 & $\begin{array}{l}1.75 \\
1.70\end{array}$ & $\begin{array}{l}87.626 \\
72.241\end{array}$ & 0.80 & 20.888 \\
\hline 1.05 & 9.428 & 1.35 & 28.687 & & & 0.75 & 17. 769 \\
\hline 1.00 & 8.675 & 1.30 & 27.077 & 1.65 & 64.259 & 0.70 & 14.286 \\
\hline 0.95 & 7.909 & 1.25 & 25.519 & 1.60 & 58.966 & 0.65 & 10.034 \\
\hline
\end{tabular}


Table 12

Theoretical phase velocity of Rayleigh waves for the case of [liquid-liquid-solid] structure when: $\rho_{2} / \rho_{1}=1.80 \quad \rho_{3} / \rho_{1}=2.70 \quad \mathrm{C}_{2} / \mathrm{C}_{1}=0.27 \quad \mathrm{C}_{3} / \mathrm{C}_{1}=3.60 \quad \mathrm{C}_{3 S} / \mathrm{C}_{1}=2.00$

\begin{tabular}{|c|c|c|c|c|c|c|c|}
\hline $\mathrm{C} / \mathrm{C}_{1}$ & $\mathrm{~L} / \mathrm{H}_{1}$ & $\mathrm{C} / \mathrm{C}_{1}$ & $\mathrm{~L} / \mathrm{H}_{1}$ & $\mathrm{C} / \mathrm{C}_{1}$ & $\mathrm{~L} / \mathrm{H}_{1}$ & $\mathrm{C} / \mathrm{C}_{1}$ & $\mathrm{~L} / \mathrm{H}$ \\
\hline \multicolumn{2}{|c|}{$\mathrm{H}_{2} / \mathrm{H}_{1}=0.20$} & 0.80 & 17. 292 & 1.20 & 57.231 & \multirow{6}{*}{$\begin{array}{l}1.60 \\
1.55 \\
1.50 \\
1.45 \\
1.40 \\
1.35 \\
1.30 \\
1.25\end{array}$} & \multirow{6}{*}{$\begin{array}{r}123.114 \\
117.537 \\
112.521 \\
107.771 \\
103.274 \\
98.953 \\
94.700 \\
90.542\end{array}$} \\
\hline 1.80 & 27.52 & $\begin{array}{l}0.75 \\
0.70\end{array}$ & $\begin{array}{l}16.018 \\
14.732\end{array}$ & $\begin{array}{l}1.15 \\
1.10\end{array}$ & $\begin{array}{l}54.571 \\
51.912\end{array}$ & & \\
\hline 1.75 & 20.46 & 0.65 & 13.434 & 1.05 & 49.287 & & \\
\hline $\begin{array}{l}1.70 \\
1.65\end{array}$ & $\begin{array}{l}18.10 \\
16.74\end{array}$ & 0.60 & \multirow{5}{*}{$\begin{array}{r}12.115 \\
10.769 \\
9.382 \\
7.933 \\
6.383 \\
4.655\end{array}$} & \multirow{4}{*}{$\begin{array}{l}1.00 \\
0.95 \\
0.90 \\
0.85 \\
0.80\end{array}$} & \multirow{4}{*}{$\begin{array}{l}46.670 \\
44.062 \\
41.461 \\
38.857 \\
36.247\end{array}$} & & \\
\hline 1.60 & 15.74 & \multirow{4}{*}{$\begin{array}{l}0.55 \\
0.50 \\
9.45 \\
0.40 \\
0.35\end{array}$} & & & & & \\
\hline 1.55 & 14.91 & & & & & & \\
\hline $\begin{array}{l}1.50 \\
1.45\end{array}$ & 14.18 & & & & & \multirow{6}{*}{$\begin{array}{l}1.20 \\
1.15 \\
1.10 \\
1.05 \\
1.00 \\
0.95 \\
0.90 \\
0.85\end{array}$} & \multirow{6}{*}{$\begin{array}{l}86.501 \\
82.465 \\
78.444 \\
74.484 \\
70.532 \\
66.590 \\
62.672 \\
58.736\end{array}$} \\
\hline $\begin{array}{l}1.45 \\
1.40\end{array}$ & $\begin{array}{l}13.51 \\
12.88\end{array}$ & & & \multirow{4}{*}{$\begin{array}{l}0.75 \\
0.70 \\
0.65 \\
0.60 \\
0.55\end{array}$} & \multirow{4}{*}{$\begin{array}{l}33.632 \\
31.001 \\
28.345 \\
25.657 \\
22.920\end{array}$} & & \\
\hline 1.35 & 12.28 & \multicolumn{2}{|c|}{$\mathrm{H}_{2} / \mathrm{H}_{1}=1.80$} & & & & \\
\hline 1. 30 & 11.69 & \multirow{4}{*}{$\begin{array}{l}1.80 \\
1.75 \\
1.70 \\
1.65 \\
1.60\end{array}$} & \multirow{4}{*}{$\begin{array}{l}95.829 \\
75.251 \\
68.171 \\
63.867 \\
60.617\end{array}$} & & & & \\
\hline $\begin{array}{l}1.25 \\
1.20\end{array}$ & $\begin{array}{l}11.12 \\
10.56\end{array}$ & & & & & & \\
\hline 1.15 & 10.00 & & & 0.50 & 20.111 & & \\
\hline 1.10 & 9.45 & & & $\begin{array}{l}0.45 \\
0.40\end{array}$ & $\begin{array}{l}\text { 17. } 192 \\
14.089\end{array}$ & \multirow{8}{*}{$\begin{array}{l}0.80 \\
0.75 \\
0.70 \\
0.65 \\
0.60 \\
0.55 \\
0.50 \\
0.45 \\
0.40 \\
0.35\end{array}$} & \multirow{8}{*}{$\begin{array}{l}54.813 \\
50.861 \\
46.899 \\
42.889 \\
38.837 \\
34.714 \\
30.483 \\
26.089 \\
21.426 \\
16.257 \\
\end{array}$} \\
\hline \multirow{3}{*}{$\begin{array}{l}1.05 \\
1.00 \\
0.95 \\
0.90 \\
0.85\end{array}$} & \multirow{4}{*}{$\begin{array}{l}8.91 \\
8.36 \\
7.81 \\
7.26 \\
6.70\end{array}$} & \multirow{4}{*}{$\begin{array}{l}1.55 \\
1.50 \\
1.45 \\
1.40 \\
1.35\end{array}$} & \multirow{4}{*}{$\begin{array}{l}57.828 \\
55.341 \\
53.006 \\
50.797 \\
48.646\end{array}$} & 0.35 & 10.643 & & \\
\hline & & & & \multicolumn{2}{|c|}{$\mathrm{H}_{2} / \mathrm{H}_{1}=3.40$} & & \\
\hline & & & & 1.80 & 161.414 & & \\
\hline 0.80 & & & & 1.75 & 127.003 & & \\
\hline 0.75 & 5.57 & $\begin{array}{l}1.30 \\
1.25\end{array}$ & 46.562 & 1.70 & 115.098 & & \\
\hline 0.70 & 4.99 & $\begin{array}{l}1.25 \\
1.20\end{array}$ & 44.525 & 1.65 & 107.844 & & \\
\hline 0.65 & 4.41 & $\begin{array}{l}1.20 \\
1.15\end{array}$ & $\begin{array}{l}42.513 \\
40.521\end{array}$ & 1.60 & 102.354 & & \\
\hline 0.60 & 3.80 & 1.00 & 38.549 & $\begin{array}{l}1.55 \\
1.50\end{array}$ & $\begin{array}{l}97.691 \\
93.490\end{array}$ & \multicolumn{2}{|c|}{$\mathrm{H}_{2} / \mathrm{H}_{1}=5.00$} \\
\hline 0.55 & 3.19 & 1.05 & 36.594 & 1.45 & 89.584 & 1.80 & 226.708 \\
\hline $\begin{array}{l}0.50 \\
0.45\end{array}$ & 2.58 & 1.00 & 34.647 & 1.40 & 85.855 & 1.75 & 178.424 \\
\hline $\begin{array}{l}0.45 \\
0.40\end{array}$ & & 0.95 & 32.702 & & 82.212 & 1.70 & 161.739 \\
\hline $\begin{array}{l}0.40 \\
0.35\end{array}$ & $\begin{array}{l}1.47 \\
0.98\end{array}$ & 0.90 & 30.763 & 1.30 & 78.712 & 1.65 & 151.673 \\
\hline 0.30 & 0.52 & 0.85 & 28.828 & 1.25 & 75.286 & 1.60 & 143.936 \\
\hline 0.25 & 0.32 & 0.80 & 26.886 & 1.20 & 71.888 & $\begin{array}{l}1.55 \\
1.50\end{array}$ & $\begin{array}{l}137.419 \\
131.466\end{array}$ \\
\hline $\mathrm{H}_{2} /$ & 1.00 & 0.70 & $\begin{array}{l}24.955 \\
22.975\end{array}$ & 1.10 & 65.213 & 1.45 & 125.909 \\
\hline 1.80 & 62.721 & $\begin{array}{l}0.65 \\
0.60\end{array}$ & $\begin{array}{l}20.996 \\
18.991\end{array}$ & 1.05 & 61.900 & $\begin{array}{l}1.40 \\
1.35\end{array}$ & $\begin{array}{l}120.712 \\
115.594\end{array}$ \\
\hline 1.75 & 49.032 & 0.55 & 16.947 & $\begin{array}{l}1.00 \\
0.95\end{array}$ & $\begin{array}{l}58.629 \\
55.341\end{array}$ & 1. 30 & 110.663 \\
\hline 1.70 & 44.329 & $\begin{array}{l}0.55 \\
0.50\end{array}$ & $\begin{array}{l}16.947 \\
14.849\end{array}$ & $\begin{array}{l}0.95 \\
0.90\end{array}$ & $\begin{array}{l}\text { 55. } 341 \\
52.080\end{array}$ & 1.25 & 105.856 \\
\hline 1.65 & 41.482 & 0.45 & 12.665 & 0.85 & 48.808 & 1.20 & 101.067 \\
\hline & 39.332 & 0.40 & 10.340 & 0.80 & 45.547 & 1.10 & $\begin{array}{l}96.345 \\
91.678\end{array}$ \\
\hline $\begin{array}{l}1.55 \\
1.50\end{array}$ & $\begin{array}{l}37.515 \\
35.875\end{array}$ & 0.35 & 7.749 & 0.75 & 42.267 & 1.05 & 87.063 \\
\hline 1.45 & 34.351 & $\mathrm{H}_{2} /$ & 2.60 & $\begin{array}{l}0.70 \\
0.65\end{array}$ & $\begin{array}{l}38.961 \\
35.632\end{array}$ & 1.00 & 82.423 \\
\hline $\begin{array}{l}1.40 \\
1.35\end{array}$ & $\begin{array}{l}32.903 \\
31.505\end{array}$ & 1.80 & 128.628 & 00 & 32.260 & $\begin{array}{l}0.95 \\
0.90\end{array}$ & $\begin{array}{l}77.836 \\
73.263\end{array}$ \\
\hline 1.30 & 30.141 & $\begin{array}{l}1.75 \\
1.70\end{array}$ & $\begin{array}{r}101.131 \\
91.678\end{array}$ & 0.55 & 28.830 & 0.85 & 68.665 \\
\hline 1. 25 & 28.808 & 1.65 & 85.900 & 0.50 & 25.309 & 0.80 & 64.070 \\
\hline 1.20 & 27.493 & 1.60 & 81.546 & 0.45 & 21.653 & 0.75 & 59.452 \\
\hline 1.15 & 26. 194 & 1.55 & 77.836 & $\begin{array}{l}0.40 \\
0.35\end{array}$ & $\begin{array}{l}17.771 \\
13.463\end{array}$ & $\begin{array}{l}0.70 \\
0.65\end{array}$ & $\begin{array}{l}54.821 \\
50.143\end{array}$ \\
\hline 1.05 & $\begin{array}{l}24.912 \\
23.635\end{array}$ & 1.50 & 74.484 & $\mathrm{H}$ & 420 & 0.60 & 45.401 \\
\hline 1.00 & 22.363 & $\begin{array}{l}1.45 \\
1.40\end{array}$ & 71.345 & & $=4.2 v$ & 0.55 & 40.583 \\
\hline 0.95 & 21.096 & 1.35 & 68.373 & 1.80 & 194.145 & 0.50 & 35.642 \\
\hline 0.90 & 19.829 & 1.30 & $\begin{array}{l}65.479 \\
62.697\end{array}$ & 1.75 & 152.681 & 0.45 & 30.512 \\
\hline 0.85 & 18.564 & 1.25 & $\begin{array}{l}62.697 \\
59.940\end{array}$ & 1.70 & 138.484 & 0.40 & $\begin{array}{l}25.067 \\
10.038\end{array}$ \\
\hline
\end{tabular}


Table 13-(a) Group velocity (U) and the period (T) of the main A-type earthquakes observation data at Mori Observatory

\begin{tabular}{|c|c|c|c|c|c|c|c|c|c|}
\hline \multicolumn{2}{|c|}{$\begin{array}{c}07^{h} 40^{m}, \text { Dec. } \\
29,1943 \\
\text { (G. M. T.) }\end{array}$} & \multirow{3}{*}{\begin{tabular}{l|}
0.744 \\
0.726 \\
0.719 \\
0.698 \\
0.674 \\
0.652 \\
0.636 \\
0.622
\end{tabular}} & \multirow{3}{*}{\begin{tabular}{l|}
1.80 \\
0.80 \\
2.23 \\
2.81 \\
2.67 \\
2.12 \\
1.91 \\
2.07
\end{tabular}} & \multirow{3}{*}{$\begin{array}{l}1.114 \\
1.118 \\
1.273 \\
1.374 \\
1.492 \\
1.632 \\
1.804\end{array}$} & \multirow{3}{*}{$\begin{array}{l}2.68 \\
3.00 \\
3.05 \\
3.11 \\
3.11 \\
3.10 \\
3.16\end{array}$} & \multirow{7}{*}{$\begin{array}{l}0.763 \\
0.751 \\
0.738 \\
0.728 \\
0.718 \\
0.710 \\
0.688 \\
0.671 \\
0.652 \\
0.638 \\
0.620 \\
0.608\end{array}$} & \multirow{7}{*}{$\begin{array}{l}1.13 \\
1.35 \\
0.96 \\
1.08 \\
0.75 \\
2.47 \\
1.99 \\
2.31 \\
1.88 \\
2.37 \\
1.83 \\
1.61\end{array}$} & $\begin{array}{l}0.774 \\
0.799 \\
0.831 \\
0.855\end{array}$ & $\begin{array}{l}1.84 \\
2.15 \\
2.57 \\
1.83\end{array}$ \\
\hline $3 \mathrm{rd} \mathrm{Pl}$ & lase & & & & & & & & \\
\hline $\mathrm{U} \mathrm{km} / \mathrm{sec}$. & $T$ sec. & & & & & & & $\begin{array}{l}0.958 \\
0.995\end{array}$ & $\begin{array}{r}2.36 \\
2.10\end{array}$ \\
\hline 0.810 & 1.89 & & & & & & & $\begin{array}{l}1.046 \\
1.094\end{array}$ & $\begin{array}{l}2.6 \\
2.2\end{array}$ \\
\hline 0.788 & 0.77 & 0.719 & 2.33 & $18^{h}, 37^{m}$, & $\begin{array}{l}16.1^{s} \\
2.1944\end{array}$ & & & 1. 151 & 2.40 \\
\hline 0.779 & 0.88 & 0.744 & 2.60 & (G. M. & T. & & & 1.219 & 2.62 \\
\hline 0.769 & 0.83 & 0.766 & $\begin{array}{l}2.01 \\
0.20\end{array}$ & & & & & 1.296 & 2.63 \\
\hline $\begin{array}{l}0.760 \\
0.750\end{array}$ & $\begin{array}{l}1.00 \\
1.00\end{array}$ & $\begin{array}{l}0.791 \\
0.819\end{array}$ & $\begin{array}{l}2.28 \\
2.33\end{array}$ & 3rd $\mathrm{Pl}$ & hase & 0.735 & 2.42 & $\begin{array}{l}1.392 \\
1.515\end{array}$ & $\begin{array}{l}2.8 \\
3.1\end{array}$ \\
\hline 0.720 & 0.77 & $\begin{array}{l}0.853 \\
0.889\end{array}$ & $\begin{array}{l}2.60 \\
2.54\end{array}$ & $\mathrm{U} \mathrm{km} / \mathrm{sec}$ & $\mathrm{T}$ sec. & $\begin{array}{l}0.761 \\
0.786\end{array}$ & $\begin{array}{l}2.52 \\
2.26\end{array}$ & $\begin{array}{l}1.662 \\
1.834\end{array}$ & $\begin{array}{l}3.1 \\
3.05\end{array}$ \\
\hline 0.712 & 1.00 & 0.928 & 2.60 & & & 0.817 & 2.58 & & \\
\hline 0.703 & 0.83 & 0.973 & 2.65 & 0.828 & 1.23 & 0.845 & 2.21 & $20^{h} 29^{m}$ & $8.2^{s}$ \\
\hline 0.696 & 1.12 & 1.022 & 2.70 & 0.813 & 1.11 & 0.877 & 2.31 & Jan. & 7, 1944 \\
\hline 0.686 & 0.94 & 1.078 & 2.70 & 0.799 & 1.76 & & & (G. I & T.) \\
\hline 0.678 & 0.71 & 1.139 & 2.71 & 0.779 & 1.64 & 0.939 & 2.36 & $3 \mathrm{rd} \mathrm{Pb}$ & hase \\
\hline $\begin{array}{l}0.672 \\
0.667\end{array}$ & $\begin{array}{l}0.53 \\
0.77\end{array}$ & $\begin{array}{l}1.211 \\
1.294\end{array}$ & $\begin{array}{l}2.81 \\
2.86\end{array}$ & $\begin{array}{l}0.761 \\
0.752\end{array}$ & $\begin{array}{l}0.81 \\
1.76\end{array}$ & 1097 & 2,47 & 3rd Pr & nase \\
\hline 0.661 & 2.42 & 1. 393 & 2.97 & 0.734 & 2.23 & 1. 158 & 2.58 & $\mathrm{U} \mathrm{km} / \mathrm{sec}$ & T sec. \\
\hline 0.642 & 2.00 & 1.511 & 3. 02 & 0.713 & 2.22 & 1. 233 & 2.85 & & \\
\hline 0.627 & 1.83 & 1.653 & 3.07 & 0.693 & 1.70 & 1.322 & 2.96 & & \\
\hline 0.614 & 2.30 & 1. 828 & 3.13 & 0.678 & 1.46 & 1.415 & 2.69 & $\begin{array}{l}0.799 \\
0.783\end{array}$ & $\begin{array}{l}1.42 \\
1.47\end{array}$ \\
\hline 0.677 & 2.07 & $15^{h} 49^{m}$ & & 0.646 & $\begin{array}{l}2.40 \\
1.93\end{array}$ & 1. 661 & 2.68 & 0.766 & 0.6 \\
\hline 0.696 & 2.18 & Jan'. & 1944 & 0.632 & 2.17 & 1.837 & 3.12 & 0.759 & 0.63 \\
\hline 0.717 & 2.30 & (G. M. & & 0.616 & 1.93 & & & $\begin{array}{l}0.752 \\
0.740\end{array}$ & $\begin{array}{l}1.21 \\
0.73\end{array}$ \\
\hline 0.759 & 2.06 & $3 \mathrm{rd} \mathrm{Ph}$ & se & 0.755 & 1. 87 & $04^{h} 46^{m}$ & & 0.733 & 1. 84 \\
\hline 0.786 & 2.54 & & & 0.779 & 2.22 & $\begin{array}{l}\text { Jan. } \\
\text { (G. } M .\end{array}$ & г.) & $\begin{array}{l}0.715 \\
0.703\end{array}$ & $\begin{array}{l}1.21 \\
1.68\end{array}$ \\
\hline 0.810 & $2.47 \|$ & $\mathrm{U} \mathrm{km} / \mathrm{sec}$ & $\mathrm{T}$ sec. & 0.802 & $\begin{array}{l}1.99 \\
2.23\end{array}$ & & & 0.688 & 2.1 \\
\hline 0.900 & 2.65 & 0.810 & 1.68 & & & $3 \mathrm{rd} \mathrm{Ph}$ & & 0.67 & 2.4 \\
\hline 0.940 & 2.54 & 0.790 & 0.90 & 0.918 & 2. 34 & $\mathrm{U} \mathrm{km} / \mathrm{sec}$ & $T$ sec & $\begin{array}{l}0.651 \\
0.637\end{array}$ & 1.7 \\
\hline 1. 049 & 2.48 & 0.780 & $1.68 \|$ & $\begin{array}{l}0.955 \\
1.004\end{array}$ & $\begin{array}{l}2.28 \\
2.76\end{array}$ & & & 0.621 & 1.9 \\
\hline 1.100 & 2.36 & 0.723 & 1.00 & & & 0.831 & 0.84 & & \\
\hline 1.169 & 2.88 & .714 & 2.47 & 1.081 & 2.34 & & & & .99 \\
\hline 1 & 2 & .700 & 1.32 & 14 & 2.75 & 0.798 & 0.78 & & 2. \\
\hline 1.3 & 2.6 & 688 & 2.05 & 1 & 2.99 & 0.789 & 1.16 & & 2.0 \\
\hline & 2.65 & 671 & 2.32 & 1.310 & 2.98 & 0.776 & 0.94 & $\begin{array}{l}0.977 \\
0.974\end{array}$ & 2.5 \\
\hline & 2.3 & 0.652 & 2.10 & 1.414 & 3.04 & 0.766 & 1.05 & $\begin{array}{l}0.31 \\
1.022\end{array}$ & $2.6^{\circ}$ \\
\hline 1.633 & & 0.636 & 1.74 & 1.552 & 3.40 & 0.755 & 1. 36 & $\begin{array}{l}1.022 \\
1.072\end{array}$ & 2.4 \\
\hline $04^{h} 43^{m}$ & & & & & 3. & $\begin{array}{l}0.740 \\
0.733\end{array}$ & $\begin{array}{l}0.74 \\
1.05\end{array}$ & & $e_{0}+$ \\
\hline $\begin{array}{l}\text { Jan. } \\
\text { (G. M. }\end{array}$ & 1944 & $\begin{array}{l}701 \\
723\end{array}$ & $\begin{array}{l}1.42 \\
2.37\end{array}$ & $10^{h} 05^{m}, 4$ & $45.8^{3}$ & 0.723 & 1.25 & 1.287 & 2.6 \\
\hline & & 0.741 & $\begin{array}{l}2.37 \\
1.79\end{array}$ & $I$ & 1944 & $\begin{array}{l}0.711 \\
0.697\end{array}$ & $\begin{array}{l}1.47 \\
1.89\end{array}$ & 1. 371 & 2.57 \\
\hline $3 \mathrm{rd} \mathrm{Ph}$ & S & & & & & & 1.78 & & \\
\hline $\mathrm{U} \mathrm{km} / \mathrm{sec}$ & $T$ sec. & $\begin{array}{l}0.787 \\
0.812\end{array}$ & $\begin{array}{l}2.31 \\
2.11\end{array}$ & 3rd $\mathrm{Ph}$ & tase & $\begin{array}{l}0.666 \\
0.647\end{array}$ & $\begin{array}{l}2.36 \\
2.05\end{array}$ & & 2.41 \\
\hline & & 0.845 & 2.63 & $\mathrm{U} \mathrm{km} / \mathrm{sec}$. & $T$ sec & 0.631 & 2.31 & & \\
\hline $\begin{array}{l}0.846 \\
0.831\end{array}$ & $\begin{array}{l}1.11 \\
1.06\end{array}$ & $\begin{array}{l}380 \\
14\end{array}$ & $\begin{array}{l}2.53 \\
2.26\end{array}$ & & & 0.615 & 1.57 & & \\
\hline & & & 3. & 23 & $0 . \varepsilon$ & & 2.47 & & \\
\hline & & & 2.47 & & & & 1. & & \\
\hline 0.777 & & 1.056 & 2.48 & 0.801 & 1.35 & 0.755 & 1.73 & & \\
\hline
\end{tabular}


(Continued)

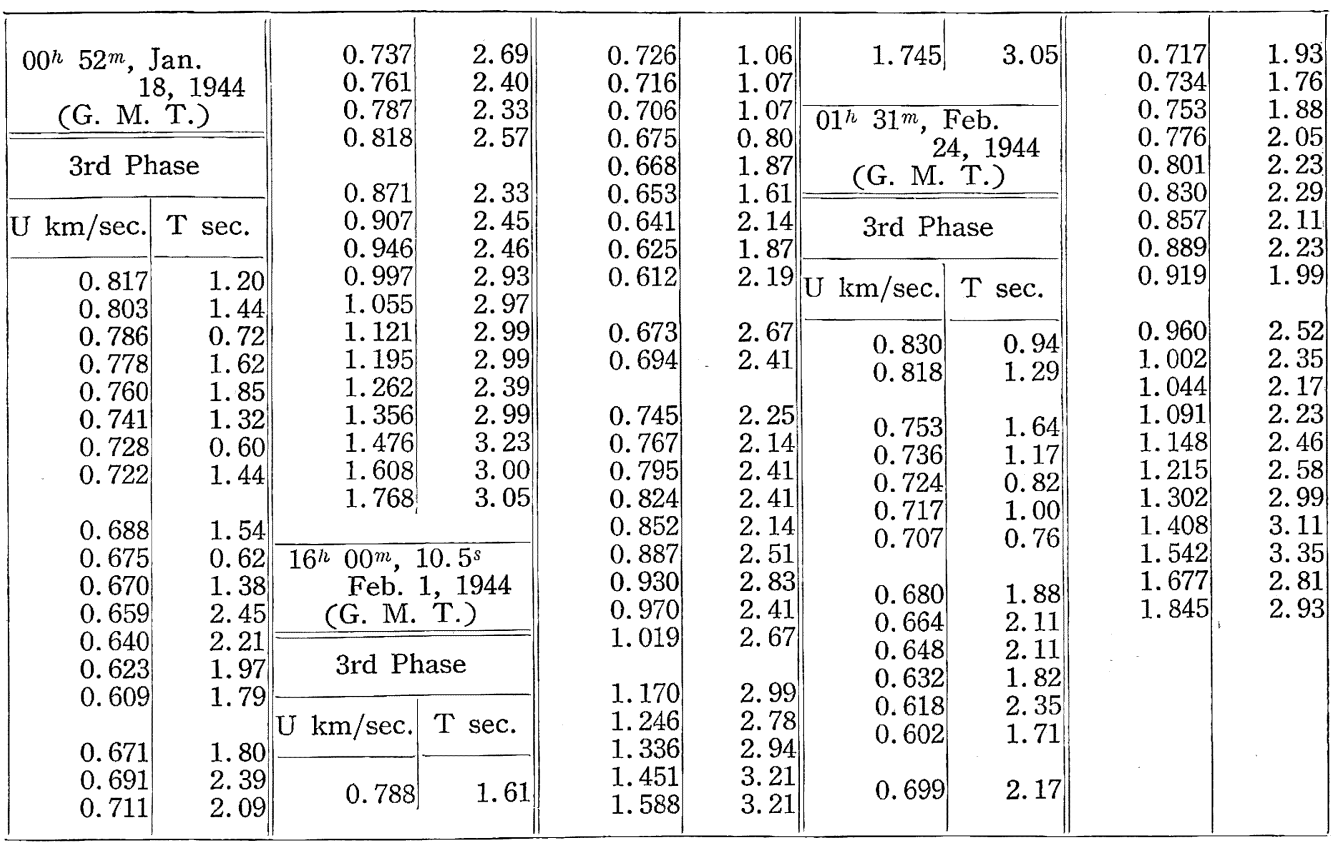

Table 13-(b). Group velocity (U) and the period (T) of the main B-type earthquakes observation data at Mori Observatory

\begin{tabular}{|c|c|c|c|c|c|c|c|c|c|c|c|}
\hline \multicolumn{4}{|c|}{$\begin{array}{l}05^{h}, 04^{m}, \text { May 29, } 1945 \\
\text { (G. M. T.) }\end{array}$} & & & \multirow{2}{*}{$\begin{array}{l}0.239 \\
0.273 \\
0.235 \\
0.233 \\
0.231\end{array}$} & \multirow{2}{*}{\begin{tabular}{l|}
1.9 \\
2.0 \\
1.6 \\
2.2 \\
1.8
\end{tabular}} & \multirow{2}{*}{$\begin{array}{l}1.348 \\
1.280 \\
1.212 \\
1.140\end{array}$} & \multirow{2}{*}{$\begin{array}{l}2.2 \\
2.4 \\
2.8 \\
2.6\end{array}$} & $\begin{array}{l}0.333 \\
0.330\end{array}$ & \multirow{2}{*}{$\begin{array}{l}1.8 \\
2.1 \\
2.1 \\
2.1\end{array}$} \\
\hline \multicolumn{2}{|c|}{ 3rd Phase } & \multicolumn{2}{|c|}{ 4th Phase } & & & & & & & 0.320 & \\
\hline $\begin{array}{c}\mathrm{U} \\
\mathrm{km} / \mathrm{sec} .\end{array}$ & $\mathrm{T}$ sec. & $\begin{array}{c}\mathrm{U} \\
\mathrm{km} / \mathrm{sec} .\end{array}$ & $\mathrm{T}$ sec. & & & $\begin{array}{l}0.231 \\
0.219\end{array}$ & $\begin{array}{l}1.8 \\
1.9\end{array}$ & $\begin{array}{l}1.000 \\
0.971\end{array}$ & $\begin{array}{l}1.6 \\
1.6\end{array}$ & $\begin{array}{l}0.310 \\
0.309\end{array}$ & 1.5 \\
\hline 1.273 & 2.3 & 0.327 & 2.1 & & & $\begin{array}{l}0.218 \\
0.216\end{array}$ & $\begin{array}{l}2.0 \\
2.3\end{array}$ & $\begin{array}{l}0.885 \\
0.858\end{array}$ & $\begin{array}{l}1.9 \\
2.0\end{array}$ & 0.300 & 1.8 \\
\hline 1.127 & 2.2 & 0.322 & 2.1 & & & 0.214 & 2.2 & 0.831 & 2.2 & 0.293 & 2.1 \\
\hline 1.078 & 1.7 & 0.318 & 1.8 & & & & & 0.805 & 1.4 & 0.290 & 1.8 \\
\hline 1.043 & 1.7 & 0.293 & 2.4 & & & 0.207 & 2.1 & 0.788 & $\begin{array}{l}2.0 \\
1.3\end{array}$ & & \\
\hline 1. 011 & 2.1 & 0.276 & 2.1 & & & $\begin{array}{l}0.205 \\
0.204\end{array}$ & $\begin{array}{l}1.9 \\
2.2\end{array}$ & 0.766 & 1.3 & $\begin{array}{l}0.283 \\
0.280\end{array}$ & $\begin{array}{l}1.9 \\
2.2\end{array}$ \\
\hline 0.973 & 2.1 & 0.273 & 2.1 & & & $\begin{array}{l}0.204 \\
0.202\end{array}$ & $\begin{array}{l}2.2 \\
2.1\end{array}$ & 0.726 & 2.1 & 0.277 & $\begin{array}{l}2.4 \\
1.7\end{array}$ \\
\hline 0.917 & 1.8 & 0.270 & 2.4 & & & 0.201 & 2.1 & 0.705 & 2.4 & 0.275 & 1.8 \\
\hline 0.890 & 1.7 & 0.267 & 2.4 & & & 0.199 & 2.1 & 0.684 & 2.2 & 0.272 & 2.1 \\
\hline 0.867 & 2.1 & 0.264 & 2.3 & \multirow{2}{*}{\multicolumn{4}{|c|}{$\begin{array}{l}02^{h} 49^{m} \text {, July 7, } 1945 \\
\text { (G. M. T.) }\end{array}$}} & 0.666 & 1.9 & 0.269 & 2.1 \\
\hline $\begin{array}{l}0.839 \\
0.811\end{array}$ & $\begin{array}{l}2.2 \\
2.1\end{array}$ & $\begin{array}{l}0.261 \\
0.258\end{array}$ & $\begin{array}{l}2.2 \\
2.2\end{array}$ & & & & & $\begin{array}{l}0.651 \\
0.637\end{array}$ & $\begin{array}{l}1.8 \\
1.6\end{array}$ & $\begin{array}{l}0.266 \\
0.264\end{array}$ & $\begin{array}{l}1.9 \\
2.1\end{array}$ \\
\hline 0.786 & 2.0 & & 1.9 & \multirow{2}{*}{\multicolumn{2}{|c|}{ 3rd Phase }} & \multirow{2}{*}{\multicolumn{2}{|c|}{ 4th Phase }} & 0.625 & 1.7 & 0.261 & 2.1 \\
\hline & 1. & 0.251 & 2.2 & & & & & & & 0.258 & 2.1 \\
\hline $\begin{array}{l}0.689 \\
0.669\end{array}$ & $\begin{array}{l}2.4 \\
2.6\end{array}$ & $\begin{array}{l}0.248 \\
0.246\end{array}$ & $\begin{array}{l}2.1 \\
2.1\end{array}$ & $\underset{\mathrm{km} / \mathrm{sec} .}{\mathrm{U}}$ & $\mathrm{T}$ sec. & $\begin{array}{c}U \\
\mathrm{~km} / \mathrm{sec} .\end{array}$ & $\mathrm{T}$ sec. & & & 0.237 & 1.7 \\
\hline 0.647 & 2.4 & 0.244 & 1.9 & & & & & & & 0.236 & 2.1 \\
\hline 0.629 & 2.0 & 0.241 & 2.2 & 1.417 & 1.9 & 0.337 & 1.7 & & & 0.233 & 2.0 \\
\hline
\end{tabular}


Table 13-(b) (Continued)

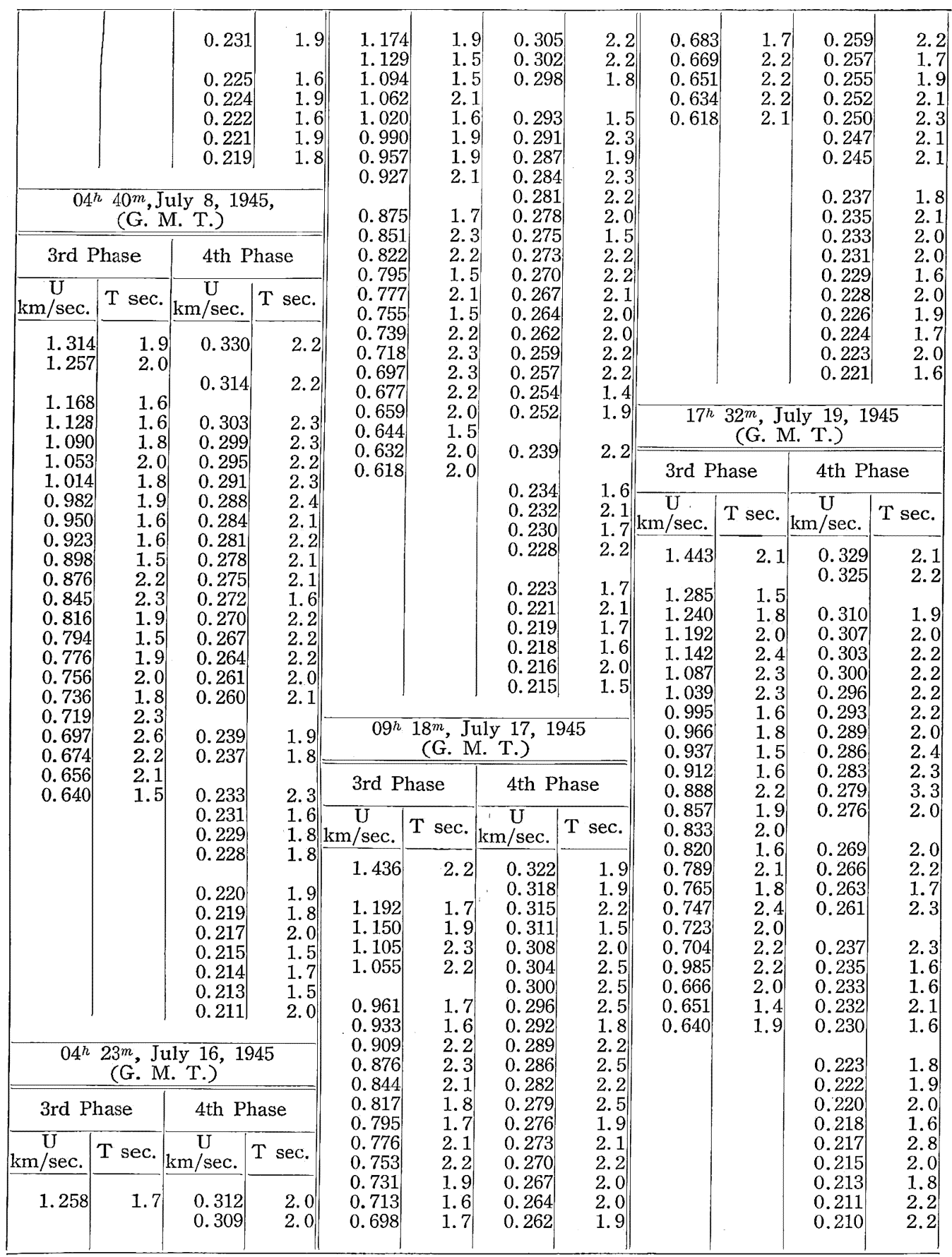


Table 13-(b) (Continued)

\begin{tabular}{|c|c|c|c|c|c|c|c|c|c|c|c|}
\hline \multicolumn{4}{|c|}{$\begin{array}{c}15^{h} 24^{m} \text { July } 22,1945, \\
\text { (G. M. T.) }\end{array}$} & \multirow{18}{*}{$\begin{array}{l}0.907 \\
0.878 \\
0.851 \\
0.828 \\
0.803 \\
0.779 \\
0.761 \\
0.738 \\
0.723 \\
0.702 \\
0.682 \\
0.661 \\
0.646 \\
0.631\end{array}$} & \multirow{7}{*}{$\begin{array}{l}2.0 \\
2.0 \\
1.8 \\
2.1 \\
2.1 \\
1.6 \\
2.2 \\
1.5 \\
2.2 \\
2.3 \\
2.5 \\
1.9\end{array}$} & \multirow{7}{*}{$\begin{array}{l}0.286 \\
0.283 \\
0.280 \\
0.277 \\
0.274 \\
0.271 \\
0.269 \\
0.266 \\
0.263 \\
0.261 \\
0.259 \\
0.256\end{array}$} & \multirow{7}{*}{\begin{tabular}{l||}
1.9 \\
2.2 \\
2.3 \\
2.3 \\
1.7 \\
1.6 \\
2.1 \\
2.2 \\
1.9 \\
2.0 \\
2.2 \\
2.3
\end{tabular}} & & & \multirow{3}{*}{$\begin{array}{l}0.241 \\
0.228 \\
0.226 \\
0.224\end{array}$} & \multirow{3}{*}{$\begin{array}{l}1.6 \\
2.3 \\
2.1 \\
2.2\end{array}$} \\
\hline \multicolumn{2}{|c|}{ 3rd Phase } & \multicolumn{2}{|c|}{ 4th Phase } & & & & & & & & \\
\hline \multirow{2}{*}{$\begin{array}{c}\mathrm{U} \\
\mathrm{km} / \mathrm{sec} .\end{array}$} & \multirow{2}{*}{$\mathrm{T}$ sec. } & $U$ & $\mathrm{~T}$ sec. & & & & & & & & \\
\hline & & & & & & & & \multirow{2}{*}{\multicolumn{4}{|c|}{$\begin{array}{c}22^{h} 02^{m} \text {, Sept. 3, } 1945 \\
\text { (G. M. T.) }\end{array}$}} \\
\hline \multirow{2}{*}{$\begin{array}{l}1.264 \\
1.214 \\
1.168\end{array}$} & \multirow{2}{*}{$\begin{array}{l}1.8 \\
1.7 \\
2.1\end{array}$} & \multirow{2}{*}{$\begin{array}{l}0.308 \\
0.305 \\
0.301 \\
0.297\end{array}$} & \multirow{3}{*}{\begin{tabular}{l||}
1.8 \\
2.2 \\
2.3 \\
2.2
\end{tabular}} & & & & & & & & \\
\hline & & & & & & & & \multicolumn{2}{|c|}{ 3rd Phase } & \multicolumn{2}{|c|}{ 4th Phase } \\
\hline 1.063 & 2.3 & 0.297 & & & & & & $\begin{array}{c}\mathrm{U} \\
\mathrm{km} / \mathrm{sec} .\end{array}$ & $\mathrm{T}$ sec. & $\begin{array}{c}\mathrm{U} \\
\mathrm{km} / \mathrm{sec} .\end{array}$ & $\mathrm{T}$ sec. \\
\hline $\begin{array}{l}1.017 \\
0.985\end{array}$ & $\begin{array}{l}1.7 \\
2.0\end{array}$ & $\begin{array}{l}0.289 \\
0.287\end{array}$ & $\begin{array}{l}1.6 \\
2.2\end{array}$ & & 2.0 & 0.249 & 2.1 & 1.343 & 1.7 & 0.329 & 2.2 \\
\hline 0.951 . & 1.6 & 0.284 & $\begin{array}{l}2.2 \\
2.3\end{array}$ & & 1.8 & 0.247 & 1.8 & 1.287 & 1.7 & & \\
\hline 0.924 & 1.5 & 0.280 & 2.1 & & & 0.245 & 2.2 & 1.237 & 1.4 & 0.311 & 2.1 \\
\hline 0.901 & 1.9 & 0.277 & 2.2 & & & 0.231 & 2.0 & 1.198 & 1.6 & 0.308 & 2.5 \\
\hline $\begin{array}{l}0.874 \\
0.847\end{array}$ & 2.0 & 0.274 & 1.5 & & & 0.229 & 1.7 & 1.037 & 16 & 0297 & \\
\hline $\begin{array}{l}0.847 \\
0.821\end{array}$ & 2.0 & 0.272 & 2.1 & & & 0.227 & 2.2 & $\begin{array}{l}1.05 \\
1.005\end{array}$ & $\begin{array}{l}1.0 \\
1.6\end{array}$ & $\begin{array}{l}0.291 \\
0.294\end{array}$ & $\begin{array}{l}2.3 \\
2.5\end{array}$ \\
\hline $\begin{array}{l}0.821 \\
0.799\end{array}$ & 1.9 & 0.269 & 2.1 & & & 0.225 & 2.0 & 0.976 & $\begin{array}{l}1.0 \\
2.2\end{array}$ & 0.290 & $\begin{array}{l}2.5 \\
2.4\end{array}$ \\
\hline & 1.5 & 0.266 & 2.1 & & & 0.223 & 2.1 & 0.936 & 1.9 & 0.286 & $\begin{array}{l}2.4 \\
2.0\end{array}$ \\
\hline $\begin{array}{l}0.781 \\
0.760\end{array}$ & $\begin{array}{l}2.0 \\
1.6\end{array}$ & 0.264 & $\begin{array}{l}2.0 \\
2.3\end{array}$ & & & 0.222 & 2.0 & 0.909 & 1.4 & 0.283 & 2.1 \\
\hline $\begin{array}{l}0.743 \\
0.722\end{array}$ & 2.1 & 0.258 & 2.0 & & & $\begin{array}{l}0.220 \\
0.218\end{array}$ & $\begin{array}{l}1.8 \\
1.8\end{array}$ & & & 0.280 & 2.3 \\
\hline $\begin{array}{l}0.722 \\
0.700\end{array}$ & 2.3 & 0.256 & 1.5 & & & & & $\begin{array}{l}0.859 \\
0.834\end{array}$ & 1.8 & 0.277 & 2.2 \\
\hline $\begin{array}{l}0.681 \\
0.663\end{array}$ & $\begin{array}{l}2.2 \\
2.2 \\
2.2\end{array}$ & $\begin{array}{l}0.254 \\
0.252\end{array}$ & $\begin{array}{l}2.1 \\
2.0\end{array}$ & $21^{h}$ & $\begin{array}{r}03^{m}, \mathrm{Al} \\
\text { (G. M }\end{array}$ & $\begin{array}{l}\text { ug. } 31,1 \mathrm{~s} \\
\text { 1. T.) }\end{array}$ & & $\begin{array}{l}0.809 \\
0.785\end{array}$ & $\begin{array}{l}2.1 \\
1.6\end{array}$ & $\begin{array}{l}0.271 \\
0.268\end{array}$ & $\begin{array}{l}2.2 \\
2.0 \\
1.5\end{array}$ \\
\hline $\begin{array}{l}0.646 \\
0.632\end{array}$ & $\begin{array}{l}1.8 \\
1.6\end{array}$ & 0.239 & 2.0 & 3rd P & hase & 4th $\mathrm{Pl}$ & hase & & 1.9 & $\begin{array}{l}0.266 \\
0.264\end{array}$ & $\begin{array}{l}1.9 \\
2.1\end{array}$ \\
\hline 0.621 & 2.1 & $\begin{array}{l}0.236 \\
0.234 \\
\end{array}$ & 2.2 & $\mathrm{U} / \mathrm{sec}$. & $\mathrm{T}$ sec. & $\begin{array}{c}\mathrm{U} \\
\mathrm{km} / \mathrm{sec} .\end{array}$ & $\mathrm{T}$ sec. & $\begin{array}{l}0.709 \\
0.692 \\
0.672\end{array}$ & $\begin{array}{l}1.8 \\
2.4 \\
2.3\end{array}$ & $\begin{array}{l}0.261 \\
0.258 \\
0.256\end{array}$ & $\begin{array}{l}2.1 \\
2.2 \\
2.2\end{array}$ \\
\hline & & $\begin{array}{l}0.231 \\
0.229\end{array}$ & $\begin{array}{l}2.3 \\
2.0\end{array}$ & 1.294 & 2.2 & 0.333 & 1.5 & 0.654 & 2.1 & 0.253 & 2.2 \\
\hline & & 0.227 & 2.0 & 1.188 & 2.0 & $\begin{array}{l}0.330 \\
0.326\end{array}$ & $\begin{array}{l}2.1 \\
2.3\end{array}$ & $\begin{array}{l}0.638 \\
0.626\end{array}$ & $\begin{array}{l}1.6 \\
1.7\end{array}$ & 0.232 & 1.6 \\
\hline & & 0.223 & 1.9 & 1.139 & 2.1 & 15 & 3 & & & $\begin{array}{l}0.231 \\
0.229\end{array}$ & 1.5 \\
\hline & & $\begin{array}{l}0.221 \\
0.220\end{array}$ & $\begin{array}{l}1.8 \\
1.6\end{array}$ & $\begin{array}{l}1.091 \\
1.045\end{array}$ & $\begin{array}{l}2.2 \\
2.0\end{array}$ & .315 & 2.3 & & & $\begin{array}{l}0.229 \\
0.227\end{array}$ & $\begin{array}{l}2.0 \\
2.2\end{array}$ \\
\hline & & 0.218 & 2.1 & 0.852 & 21 & 0.311 & 2.7 & & & & \\
\hline & & $\begin{array}{l}0.217 \\
0.215\end{array}$ & $\begin{array}{l}2.2 \\
2.2\end{array}$ & $\begin{array}{l}0.052 \\
0.825\end{array}$ & $\begin{array}{l}2.1 \\
2.3\end{array}$ & $\begin{array}{l}0.302 \\
0.299\end{array}$ & $\begin{array}{l}1.6 \\
2.3\end{array}$ & & & & \\
\hline & & 0.213 & 2.2 & & & 0.295 & 2.4 & & & & \\
\hline & & $\begin{array}{l}0.211 \\
0.209\end{array}$ & 2.2 & $\begin{array}{l}0.760 \\
0.741\end{array}$ & 1.7 & 0.291 & 2.2 & & & & \\
\hline & & & & 0.724 & $\begin{array}{l}1.8 \\
2.3\end{array}$ & $\begin{array}{l}0.288 \\
0.285\end{array}$ & $\begin{array}{l}2.0 \\
2.3\end{array}$ & & & & \\
\hline $11^{h}$ & $\begin{array}{r}15^{m}, \mathrm{~A} \\
(\mathrm{G} . \mathrm{M} \\
\end{array}$ & $\begin{array}{l}\text { ug. } 4,19 \\
\text { I. T.) }\end{array}$ & & $\begin{array}{l}0.702 \\
0.684 \\
0.665\end{array}$ & $\begin{array}{l}2.1 \\
2.3 \\
2.3\end{array}$ & $\begin{array}{l}0.281 \\
0.279 \\
0.275\end{array}$ & 2.0 & & & & \\
\hline 3rd Pl & hase & 4th $\mathrm{Pl}$ & se & 0.647 & 2.0 & 0.272 & 2.2 & & & & \\
\hline $\begin{array}{c}\mathrm{U} \\
\mathrm{km} / \mathrm{sec}\end{array}$ & $\mathrm{T}$ sec. & $\begin{array}{c}\mathrm{U} \\
\mathrm{km} / \mathrm{sec}\end{array}$ & $\mathrm{T}$ sec. & 0.620 & 1.9 & $\begin{array}{l}0.267 \\
0.264\end{array}$ & 2.1 & & & & \\
\hline 1.285 & 2.2 & 0.331 & 2.4 & & & $\begin{array}{l}0.262 \\
0.259\end{array}$ & $\begin{array}{l}2.2 \\
2.0\end{array}$ & & & & \\
\hline 1.137 & 1.5 & 0.305 & 2 & & & $\begin{array}{l}0.257 \\
0.254\end{array}$ & $\begin{array}{l}2.1 \\
2.0\end{array}$ & & & & \\
\hline 1.102 & 1.6 & 0.301 & 2.2 & & & & & & & & \\
\hline 1.066 & 2.0 & 0.297 & 2.4 & & & 0.249 & 2.3 & & & & \\
\hline 1.026 & 1.9 & .293 & 2.3 & & & 0.246 & 2.2 & & & & \\
\hline 0.991 & 2.3 & 0.290 & 2.2 & & & 0.244 & 2.1 & & & & \\
\hline
\end{tabular}


Table 14-(1)

Theoretical phase velocity of Rayleigh waves for the case of [liquid-solid-solid] structure

(a) Fundamental mode

when: $\quad \rho_{2} / \rho_{1}=1.80 \quad \rho_{3} / \rho_{1}=2.70 \quad \mathrm{C}_{2} / \mathrm{C}_{1}=0.69 \quad \mathrm{C}_{2 S} / \mathrm{C}_{1}=0.40 \quad \mathrm{C}_{3} / \mathrm{C}_{1}=3.60 \quad \mathrm{C}_{3 S} / \mathrm{C}_{1}=2.00$

\begin{tabular}{|c|c|c|c|c|c|c|c|}
\hline $\mathrm{C} / \mathrm{C}_{1}$ & $\mathrm{~L} / \mathrm{H}_{1}$ & $\mathrm{C} / \mathrm{C}_{1}$ & $\mathrm{~L} / \mathrm{H}_{1}$ & $\mathrm{C} / \mathrm{C}_{1}$ & $\mathrm{~L} / \mathrm{H}_{1}$ & $\mathrm{C} / \mathrm{C}_{1}$ & $\mathrm{~L} / \mathrm{H}_{1}$ \\
\hline \multicolumn{2}{|c|}{$\mathrm{H}_{2} / \mathrm{H}_{1}=0.20$} & 0.45 & 3. 171 & \multirow{2}{*}{$\begin{array}{l}0.50 \\
0.45\end{array}$} & $\begin{array}{l}8.562 \\
7.373\end{array}$ & \multirow{2}{*}{$\begin{array}{l}0.55 \\
0.50 \\
0.45\end{array}$} & \multirow{2}{*}{$\begin{array}{l}14.680 \\
12.979 \\
11.149\end{array}$} \\
\hline 1.80 & 22.816 & \multicolumn{2}{|c|}{$\mathrm{H}_{2} / \mathrm{H}_{1}=1.80$} & & & & \\
\hline 1.75 & 13.716 & \multirow{28}{*}{$\begin{array}{l}1.80 \\
1.75 \\
1.70 \\
1.65 \\
1.60 \\
1.55 \\
1.50 \\
1.45 \\
1.40 \\
1.35 \\
1.30 \\
1.25 \\
1.20 \\
1.15 \\
1.10 \\
1.05 \\
1.00 \\
0.95 \\
0.90 \\
0.85 \\
0.80 \\
0.75 \\
0.70 \\
0.65 \\
0.60 \\
0.55 \\
0.50 \\
0.45 \\
\end{array}$} & \multirow{17}{*}{$\begin{array}{l}84.192 \\
50.023 \\
39.829 \\
34.842 \\
31.716 \\
29.424 \\
27.573 \\
25.962 \\
24.502 \\
23.132 \\
21.817 \\
20.541 \\
19.285 \\
18.037 \\
16.789 \\
15.532\end{array}$} & \multicolumn{2}{|c|}{$\mathrm{H}_{2} / \mathrm{H}_{1}=3.40$} & \multirow{2}{*}{\multicolumn{2}{|c|}{$\mathrm{H}_{2} / \mathrm{H}_{1}=5.00$}} \\
\hline $\begin{array}{l}1.70 \\
1.65\end{array}$ & $\begin{array}{r}11.017 \\
9.662\end{array}$ & & & \multirow{5}{*}{$\begin{array}{l}1.80 \\
1.75 \\
1.70 \\
1.65 \\
1.60\end{array}$} & \multirow{3}{*}{$\begin{array}{r}147.365 \\
89.039\end{array}$} & & \\
\hline 1.60 & 8.782 & & & & & \multirow{27}{*}{$\begin{array}{l}1.80 \\
1.75 \\
1.70 \\
1.65 \\
1.60 \\
1.55 \\
1.50 \\
1.45 \\
1.40 \\
1.35 \\
1.30 \\
1.25 \\
1.20 \\
1.15 \\
1.10 \\
1.05 \\
1.00 \\
0.95 \\
0.90 \\
0.85 \\
0.80 \\
0.75 \\
0.70 \\
0.65 \\
0.60 \\
0.55 \\
0.50 \\
0.45\end{array}$} & \multirow{27}{*}{$\begin{array}{r}210.673 \\
128.320 \\
104.549 \\
93.003 \\
85.672 \\
80.164 \\
75.533 \\
71.409 \\
67.569 \\
63.917 \\
60.367 \\
56.907 \\
53.465 \\
50.038 \\
46.589 \\
43.117 \\
39.574 \\
35.948 \\
32.186 \\
28.353 \\
26.405 \\
24.585 \\
22.764 \\
20.929 \\
19.065 \\
17.152 \\
15.151 \\
12.989\end{array}$} \\
\hline 1.55 & 8.115 & & & & & & \\
\hline 1.50 & 7.563 & & & & 63.765 & & \\
\hline 1.45 & 7.076 & & & & 58.586 & & \\
\hline 1.40 & 6.631 & & & 1.55 & 54.701 & & \\
\hline 1.35 & 6.212 & & & 1.50 & 51.496 & & \\
\hline 1.30 & 5.811 & & & 1.45 & 48.631 & & \\
\hline 1.25 & 5.421 & & & 1.40 & 46.003 & & \\
\hline 1.20 & 5.038 & & & 1.35 & 43.502 & & \\
\hline 1.15 & 4.658 & & & 1.30 & 41.080 & & \\
\hline 1. 10 & 4.279 & & & 1.25 & 38.707 & & \\
\hline 1.05 & 3.899 & & & 1.20 & 36.362 & & \\
\hline 1.00 & 3.515 & & & 1.15 & 34.031 & & \\
\hline 0.95 & 3.130 & & & 1.10 & 31.685 & & \\
\hline 0.90 & 2.746 & & & 1.05 & 29.322 & & \\
\hline 0.85 & 2. 373 & & 13.389 & 1.00 & 26.913 & & \\
\hline 0.80 & 2.028 & & 12.597 & 0.95 & 24.443 & & \\
\hline 0.75 & 1.725 & & 11.812 & 0.90 & 21.888 & & \\
\hline 0.70 & 1.471 & & 11.031 & 0.85 & 20.049 & & \\
\hline 0.65 & 1.259 & & 10.252 & 0.80 & 18.752 & & \\
\hline 0.60 & 1.079 & & 9.472 & 0.75 & 17.461 & & \\
\hline 0.55 & 0.922 & & 8.688 & 0.70 & 16.167 & & \\
\hline 0.50 & 0.780 & & 7.897 & 0.65 & 14.863 & & \\
\hline 0.45 & 0.643 & & 7.090 & 0.60 & 13.544 & & \\
\hline \multirow{2}{*}{\multicolumn{2}{|c|}{$\mathrm{H}_{2} / \mathrm{H}_{1}=1.00$}} & & 5.373 & \multirow{2}{*}{$\begin{array}{l}0.50 \\
0.45 \\
\end{array}$} & & & \\
\hline & & & & & & & \\
\hline 1.80 & 52.905 & $\mathrm{H}_{2} /$ & 2.60 & & & & \\
\hline 1.75 & 31.038 & 1.80 & 115.677 & $\mathrm{H}_{2} /$ & 4.20 & & \\
\hline 1.70 & 24.434 & 1.75 & 69.436 & 1.80 & 179.020 & & \\
\hline 1.65 & 21.156 & 1.70 & 55.821 & 1.75 & 108.645 & & \\
\hline 1.60 & 19.082 & 1.65 & 49.227 & 1.70 & 88.257 & & \\
\hline 1.55 & 17.568 & 1.60 & 45.074 & 1.65 & 78.367 & & \\
\hline 1.50 & 16.359 & 1.55 & 42.013 & 1.60 & 72.113 & & \\
\hline 1.45 & & 1.50 & 39.486 & 1.55 & 67.428 & & \\
\hline 1. 40 & & 1.45 & 37.272 & 1.50 & 63.514 & & \\
\hline 1.35 & 13.616 & 1.40 & 35.231 & 1.45 & 60.029 & & \\
\hline 1.30 & 12.867 & 1.35 & 33.298 & 1.40 & 56.787 & & \\
\hline 1.25 & & 1.30 & 31.437 & 1.35 & 53.714 & & \\
\hline 1.20 & & 1.25 & 29.614 & 1.30 & 50.733 & & \\
\hline 1.15 & 10.907 & 1.20 & 27.816 & 1.25 & 47.807 & & \\
\hline 1.10 & & 1.15 & 26.029 & 1.20 & 44.911 & & \\
\hline 1.05 & 9.745 & 1.10 & 24.233 & 1.15 & 42.035 & & \\
\hline 1.00 & 9.185 & 1.05 & 22.422 & 1.10 & 39.140 & & \\
\hline 0.95 & 8.635 & 1.00 & 20.580 & 1.05 & 36.215 & & \\
\hline 0.90 & 8.090 & 0.95 & 18.693 & 1.00 & 33.243 & & \\
\hline 0.85 & 7.549 & 0.90 & 16.989 & 0.95 & 30.197 & & \\
\hline 0.80 & 7.010 & 0.85 & 15.948 & 0.90 & 27.040 & & \\
\hline 0.75 & 6.473 & 0.80 & 14.912 & 0.85 & 24.147 & & \\
\hline 0.70 & 5.935 & 0.75 & 13. 878 & 0.80 & 22.580 & & \\
\hline 0.65 & 5.396 & 0.70 & 12.844 & 0.75 & 21.027 & & \\
\hline 0.60 & 4.854 & 0.65 & 11.804 & 0.70 & 19. 469 & & \\
\hline 0.55 & 4. 307 & 0.60 & 10.751 & 0.65 & 17.901 & & \\
\hline 0.50 & 3.749 & 0.55 & 9.677 & 0.60 & 16.310 & & \\
\hline
\end{tabular}


(b) Higher mode

when: $\rho_{2} / \rho_{1}=1.80 \quad \rho_{3} / \rho_{1}=2.70 \quad \mathrm{C}_{2} / \mathrm{C}_{1}=0.69 \quad \mathrm{C}_{2} / \mathrm{C}_{1}=0.40 \quad \mathrm{C}_{3} / \mathrm{C}_{1}=3.60 \quad \mathrm{C}_{3 S} / \mathrm{C}_{1}=2.00$

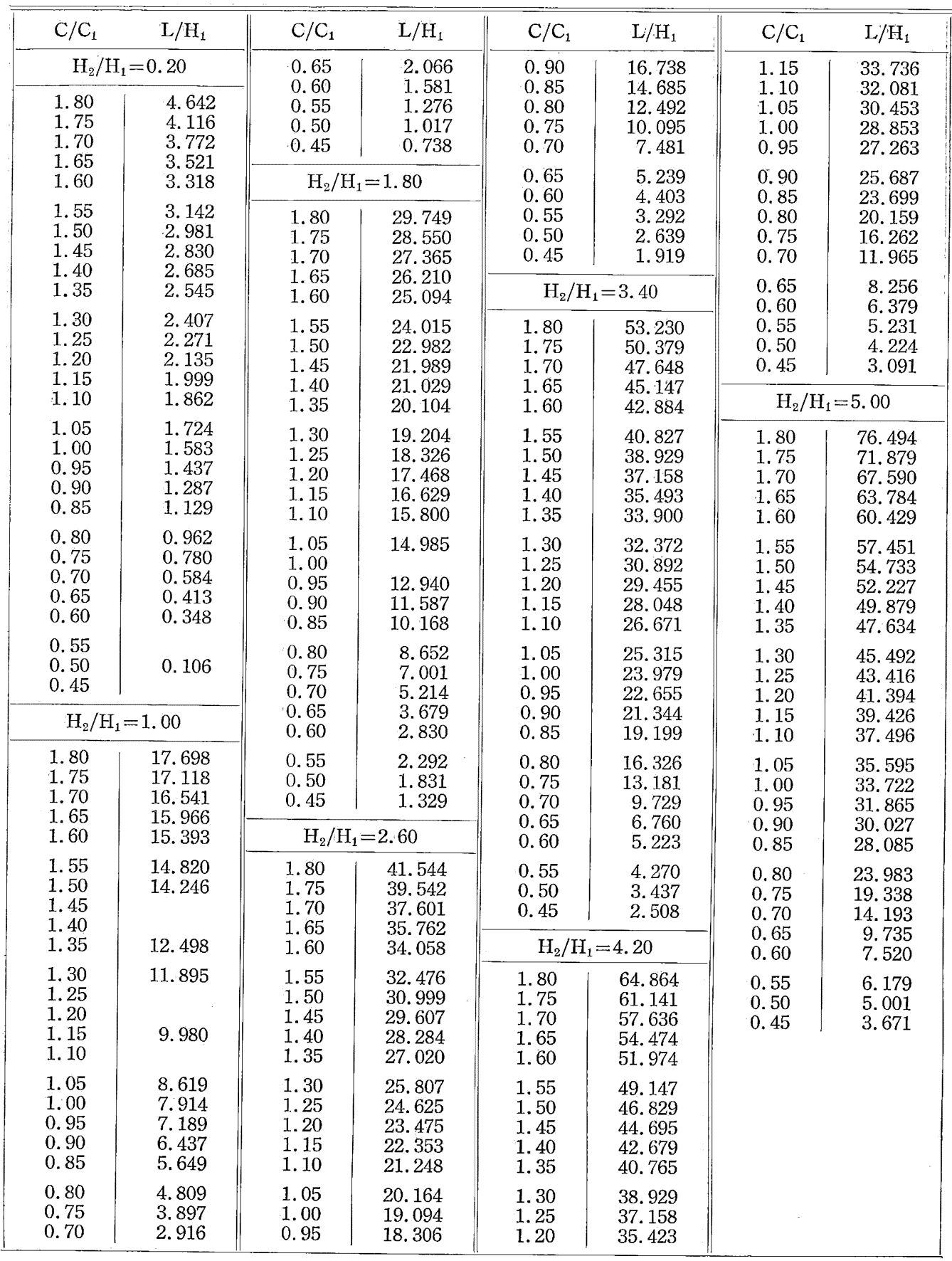


Table 14-(2)

Theoretical phase velocity of Rayleigh waves for the case of [liquid-solid-solid] structure (a) Fundamental mode

when: $\rho_{2} / \rho_{1}=1.80 \quad \rho_{3} / \rho_{1}=2.70 \quad \mathrm{C}_{2} / \mathrm{C}_{1}=0.69 \quad \mathrm{C}_{2} \mathrm{~S} / \mathrm{C}_{1}=0.40 \quad \mathrm{C}_{3} / \mathrm{C}_{1}=3.60 \quad \mathrm{C}_{3 S} / \mathrm{C}_{1}=2.00$

\begin{tabular}{|c|c|c|c|c|c|c|c|}
\hline $\mathrm{C} / \mathrm{C}_{1}$ & $\mathrm{~L} / \mathrm{H}_{1}$ & $\mathrm{C} / \mathrm{C}_{1}$ & $\mathrm{~L} / \mathrm{H}_{1}$ & $\mathrm{C} / \mathrm{C}_{1}$ & $\mathrm{~L} / \mathrm{H}_{1}$ & $\mathrm{C} / \mathrm{C}_{1}$ & $\mathrm{~L} / \mathrm{H}_{1}$ \\
\hline \multicolumn{2}{|c|}{$\mathrm{H}_{2} / \mathrm{H}_{1}=3.50$} & $\begin{array}{l}1.10 \\
1.05\end{array}$ & $\begin{array}{l}33.548 \\
31.043\end{array}$ & $\begin{array}{l}1.75 \\
1.70\end{array}$ & $\begin{array}{l}98.832 \\
80.124\end{array}$ & $\begin{array}{l}0.95 \\
0.90\end{array}$ & $\begin{array}{l}28.039 \\
25.107\end{array}$ \\
\hline \multirow{3}{*}{$\begin{array}{l}1.80 \\
1.75 \\
1.70\end{array}$} & 151.387 & 1.00 & 28.496 & 1.65 & 71.062 & 0.85 & 22.608 \\
\hline & $\begin{array}{l}91.469 \\
74.038\end{array}$ & 0.95 & 25.882 & 1.60 & 65.346 & 0.80 & 21.146 \\
\hline & 74.038 & 0.90 & 23.175 & 1.55 & 61.055 & 0.75 & $\begin{array}{l}21.140 \\
19.691\end{array}$ \\
\hline \multirow{3}{*}{$\begin{array}{l}1.65 \\
1.60 \\
1.55\end{array}$} & 65.585 & 0.85 & 21.071 & 1.50 & 57.497 & 0.70 & 18.232 \\
\hline & $\begin{array}{l}60.277 \\
56.290\end{array}$ & 0.80 & & 1.45 & 54.331 & 0.65 & 16.764 \\
\hline & & 0.75 & 18. 353 & 1.40 & 51.397 & 0.60 & 15.275 \\
\hline \multirow{3}{*}{$\begin{array}{l}1.50 \\
1.45 \\
1.40\end{array}$} & 52.989 & 0.70 & 16.993 & 1.35 & 48.602 & 0.55 & 13.750 \\
\hline & $\begin{array}{l}50.054 \\
47.343\end{array}$ & 0.65 & 15.625 & 1. 30 & 45.898 & 0.50 & 12.161 \\
\hline & 47.340 & 0.60 & 14.238 & 1.25 & 43.256 & 0.45 & 10.453 \\
\hline \multirow{2}{*}{$\begin{array}{l}1.35 \\
1.30 \\
1.25\end{array}$} & $\begin{array}{l}44.773 \\
42.289\end{array}$ & 0.55 & 12.817 & 1.20 & 40.633 & \multicolumn{2}{|c|}{$\mathrm{H}_{2} / \mathrm{H}_{1}=4.00$} \\
\hline & 39.848 & $\begin{array}{l}0.50 \\
0.45\end{array}$ & $\begin{array}{r}11.339 \\
9.753\end{array}$ & $\begin{array}{l}1.15 \\
1.10\end{array}$ & \multirow{2}{*}{$\begin{array}{l}38.030 \\
35.409 \\
32.769\end{array}$} & 1.80 & 171.207 \\
\hline \multirow{2}{*}{$\begin{array}{l}1.20 \\
1.15 \\
1.10\end{array}$} & $\begin{array}{l}37.437 \\
35.032\end{array}$ & \multicolumn{2}{|c|}{$\mathrm{H}_{2} / \mathrm{H}_{1}=3.70$} & 1.05 & & 1.70 & 84.192 \\
\hline & 32.616 & 1.80 & 159.178 & $\begin{array}{l}1.00 \\
0.95\end{array}$ & $\begin{array}{l}30.079 \\
27.320\end{array}$ & 1.65 & 74.726 \\
\hline \multirow{3}{*}{$\begin{array}{l}1.05 \\
1.00 \\
0.95\end{array}$} & 30.180 & $\begin{array}{l}1.75 \\
1.70\end{array}$ & $\begin{array}{l}96.408 \\
78.063\end{array}$ & 0.90 & 24.465 & $\begin{array}{l}1.60 \\
1.55\end{array}$ & $\begin{array}{l}68.724 \\
64.249\end{array}$ \\
\hline & $\begin{array}{l}27.706 \\
25.162\end{array}$ & & 10.000 & 0.85 & 22.096 & & \\
\hline & & $\begin{array}{l}1.65 \\
1.60\end{array}$ & $\begin{array}{l}69.227 \\
63.639\end{array}$ & 0.80 & & $\begin{array}{l}1.50 \\
1.45\end{array}$ & $\begin{array}{l}60.503 \\
57.170\end{array}$ \\
\hline \multirow{2}{*}{$\begin{array}{l}0.90 \\
0.85 \\
0.80\end{array}$} & $\begin{array}{l}22.532 \\
20.559\end{array}$ & 1.55 & 59.474 & 0.75 & 19.245 & 1.40 & 54.094 \\
\hline & & 1.50 & 55.996 & 0.70 & 17.819 & 1.35 & 51.152 \\
\hline \multirow{3}{*}{$\begin{array}{l}0.75 \\
0.70 \\
0.65\end{array}$} & 17.907 & 1.45 & 52.902 & $\begin{array}{l}0.6 b \\
0.60\end{array}$ & $\begin{array}{l}16.384 \\
14.930\end{array}$ & 1.30 & 48. 310 \\
\hline & 16.580 & 1.40 & 50.038 & & & $1.2 b$ & 45.534 \\
\hline & 15.245 & 1.35 & 47.329 & $\begin{array}{l}0.55 \\
0.50\end{array}$ & $\begin{array}{l}13.440 \\
11.888\end{array}$ & 1.20 & 42.773 \\
\hline \multirow{2}{*}{$\begin{array}{l}0.60 \\
0.55 \\
0.50\end{array}$} & $\begin{array}{l}13.891 \\
12.506\end{array}$ & $\begin{array}{l}1.30 \\
1.25\end{array}$ & $\begin{array}{l}44.699 \\
42.123\end{array}$ & 0.45 & 10.220 & $\begin{array}{l}1.15 \\
1.10\end{array}$ & $\begin{array}{l}40.027 \\
37.272\end{array}$ \\
\hline & 11.064 & 1.20 & 39.574 & \multicolumn{2}{|c|}{$\mathrm{H}_{2} / \mathrm{H}_{1}=3.90$} & 1.05 & 34.491 \\
\hline 0.45 & 9.518 & $\begin{array}{l}1.15 \\
1.10\end{array}$ & $\begin{array}{l}37.032 \\
34.483\end{array}$ & 1.80 & 167.116 & $\begin{array}{l}1.00 \\
0.95\end{array}$ & $\begin{array}{l}31.660 \\
28.756\end{array}$ \\
\hline \multicolumn{2}{|c|}{$\mathrm{H}_{2} / \mathrm{H}_{1}=3.60$} & 1.05 & 31.905 & 1.70 & 82.128 & 0.90 & 25.750 \\
\hline \multirow{2}{*}{$\begin{array}{l}1.80 \\
1.75 \\
1.70\end{array}$} & $\begin{array}{r}155.335 \\
93.926\end{array}$ & $\begin{array}{l}1.00 \\
0.95\end{array}$ & $\begin{array}{l}29.285 \\
26.602\end{array}$ & $\begin{array}{l}1.65 \\
1.60\end{array}$ & $\begin{array}{l}72.898 \\
67.034\end{array}$ & $\begin{array}{l}0.85 \\
0.80\end{array}$ & 21.624 \\
\hline & 76.033 & 0.90 & 23.820 & 1.55 & 62.648 & 0.75 & 20.136 \\
\hline \multirow{2}{*}{$\begin{array}{l}1.65 \\
1.60 \\
1.55\end{array}$} & $\begin{array}{l}67.428 \\
61.948\end{array}$ & $\begin{array}{l}0.85 \\
0.80\end{array}$ & 21.583 & $\begin{array}{l}1.50 \\
1.45\end{array}$ & $\begin{array}{l}58.994 \\
55.744\end{array}$ & $\begin{array}{l}0.70 \\
0.65\end{array}$ & $\begin{array}{l}18.645 \\
17.144\end{array}$ \\
\hline & 57.890 & 0.75 & 18.799 & 1.40 & 52.746 & 0.60 & 15.620 \\
\hline \multirow{3}{*}{$\begin{array}{l}1.50 \\
1.45 \\
1.40\end{array}$} & 54.497 & 0.70 & $\begin{array}{l}17.407 \\
16.005\end{array}$ & 1.35 & 49.883 & $\begin{array}{l}0.55 \\
0.50\end{array}$ & $\begin{array}{l}14.060 \\
12.434\end{array}$ \\
\hline & 51.480 & 0.65 & 16.005 & 1. 30 & 47. 107 & & 12.434 \\
\hline & 48.690 & 0.60 & 14.584 & $1.2 b$ & 44.390 & 0.45 & 10.685 \\
\hline \multirow{2}{*}{$\begin{array}{l}1.35 \\
1.30 \\
1.25\end{array}$} & 46.055 & $\begin{array}{l}0.55 \\
0.50\end{array}$ & $\begin{array}{l}13.128 \\
11.613\end{array}$ & 1.20 & 41.708 & & \\
\hline & $\begin{array}{l}43.490 \\
40.985\end{array}$ & 0.45 & 9.986 & $\begin{array}{l}1.15 \\
1.10\end{array}$ & $\begin{array}{l}39.026 \\
36.346\end{array}$ & & \\
\hline \multirow{2}{*}{$\begin{array}{l}1.20 \\
1.15\end{array}$} & \multirow{2}{*}{$\begin{array}{l}38.503 \\
36.028\end{array}$} & $\mathrm{H}_{2} / \mathrm{I}$ & $=3.80$ & 05 & 33.632 & & \\
\hline & & 1.80 & 163.216 & 1.00 & 30.870 & & \\
\hline
\end{tabular}


(b) Higher mode

when: $\quad \rho_{2} / \rho_{1}=1.80 \quad \rho_{3} / \rho_{1}=2.70 \quad \mathrm{C}_{2} / \mathrm{C}_{1}=0.69 \quad \mathrm{C}_{2 S} / \mathrm{C}_{1}=0.40 \quad \mathrm{C}_{3} / \mathrm{C}_{1}=3.60 \quad \mathrm{C}_{3 S} / \mathrm{C}_{1}=2.00$

\begin{tabular}{|c|c|c|c|c|c|c|c|}
\hline $\mathrm{C} / \mathrm{C}_{1}$ & $\mathrm{~L} / \mathrm{H}_{1}$ & $\mathrm{C} / \mathrm{C}_{1}$ & $\mathrm{~L} / \mathrm{H}_{1}$ & $\mathrm{C} / \mathrm{C}_{1}$ & $\mathrm{~L} / \mathrm{H}_{1}$ & $\mathrm{C} / \mathrm{C}_{1}$ & $\mathrm{~L} / \mathrm{H}_{1}$ \\
\hline \multicolumn{2}{|c|}{$\mathrm{H}_{2} / \mathrm{H}_{1}=3.50$} & \multirow{2}{*}{$\begin{array}{l}1.10 \\
1.05 \\
1.00\end{array}$} & \multirow{2}{*}{$\begin{array}{l}28.023 \\
26.600 \\
25.196\end{array}$} & \multirow{2}{*}{$\begin{array}{l}1.75 \\
1.70 \\
1.65\end{array}$} & \multirow{2}{*}{$\begin{array}{l}55.758 \\
52.655 \\
49.817\end{array}$} & \multirow{2}{*}{$\begin{array}{l}0.95 \\
0.90 \\
0.85\end{array}$} & \multirow{2}{*}{$\begin{array}{l}25.536 \\
24.062 \\
22.016\end{array}$} \\
\hline 1.80 & 54.696 & & & & & & \\
\hline \multirow{2}{*}{1.70} & \multirow{2}{*}{48.908} & 0.95 & 23.809 & 1.60 & 47.284 & 0.80 & 18.722 \\
\hline & & 0.90 & 22.431 & 1.55 & 44.983 & $\begin{array}{l}0.00 \\
0.75\end{array}$ & 15. 107 \\
\hline \multirow{3}{*}{$\begin{array}{l}1.65 \\
1.60 \\
1.55\end{array}$} & \multirow{3}{*}{$\begin{array}{l}46.317 \\
43.986 \\
41.868\end{array}$} & 0.85 & 20.325 & 1.50 & 42.884 & 0.70 & 11. 127 \\
\hline & & \multirow{2}{*}{$\begin{array}{l}0.80 \\
0.75\end{array}$} & \multirow{3}{*}{$\begin{array}{l}13.952 \\
10.289\end{array}$} & 1.45 & \multirow{3}{*}{$\begin{array}{l}40.931 \\
39.090 \\
37.339\end{array}$} & \multirow{3}{*}{$\begin{array}{l}0.65 \\
0.60 \\
0.55\end{array}$} & \multirow{3}{*}{$\begin{array}{l}7.697 \\
5.948 \\
4.873\end{array}$} \\
\hline & & & & 1.40 & & & \\
\hline \multirow{2}{*}{$\begin{array}{l}1.50 \\
1.45\end{array}$} & 39.915 & 0.70 & & 1.35 & & & \\
\hline & $\begin{array}{l}38.100 \\
36.393\end{array}$ & 0.65 & 7.136 & 1.30 & \multirow{3}{*}{$\begin{array}{l}35.651 \\
34.022 \\
32.443\end{array}$} & 0.50 & \multirow{2}{*}{$\begin{array}{l}3.930 \\
2.873\end{array}$} \\
\hline & & 0.60 & 5.514 & 1.25 & & 0.45 & \\
\hline $\begin{array}{l}1.35 \\
1.30\end{array}$ & $\begin{array}{l}34.757 \\
33.193\end{array}$ & 0.55 & 4.512 & 1.20 & & $\mathrm{H}_{2} /$ & 4.00 \\
\hline 1.25 & 31.677 & 0.50 & 3.635 & 1. 15 & 30.892 & 1.80 & 61.966 \\
\hline 1.20 & 30.202 & 0.45 & 2.654 & $\begin{array}{l}1.10 \\
1.05\end{array}$ & $\begin{array}{l}29.380 \\
27.887\end{array}$ & 1.75 & 58.453 \\
\hline 1.15 & 28.760 & $\mathrm{H}_{2} / \mathrm{H}$ & 3.70 & & 27.008 & 1.70 & 55.146 \\
\hline 1.10 & 27.347 & 1.80 & 57.595 & $\begin{array}{l}1.00 \\
0.95\end{array}$ & $\begin{array}{l}26.417 \\
24.962\end{array}$ & 1.65 & 52.143 \\
\hline 1.05 & 25.957 & $\begin{array}{l}1.75 \\
1.70\end{array}$ & $\begin{array}{l}54.418 \\
51.409\end{array}$ & 0.90 & 23.516 & $\begin{array}{l}1.60 \\
1.55\end{array}$ & $\begin{array}{l}49.480 \\
47.062\end{array}$ \\
\hline $\begin{array}{l}1.00 \\
0.95\end{array}$ & $\begin{array}{l}24.588 \\
23.231\end{array}$ & & & 0.85 & 21.452 & & \\
\hline 0.90 & 23.231 & 1.65 & 48. 657 & 0.80 & & 1.50 & 44. 857 \\
\hline $\begin{array}{l}0.90 \\
0.85\end{array}$ & $\begin{array}{l}21.887 \\
19.763\end{array}$ & $\begin{array}{l}1.60 \\
1.55\end{array}$ & $\begin{array}{l}46.184 \\
43.950\end{array}$ & 0.75 & 14.722 & $\begin{array}{l}1.45 \\
1.40\end{array}$ & 40.889 \\
\hline 0.80 & & 1.50 & 41.890 & 0.70 & 10.848 & 1.35 & 39052 \\
\hline 0.75 & 13.567 & 1.45 & 39.984 & $\begin{array}{l}0.65 \\
0.60\end{array}$ & $\begin{array}{l}7.510 \\
5.804\end{array}$ & 1.30 & 37.296 \\
\hline 0.70 & 10.009 & 1.40 & 38.190 & & 5.804 & 1.25 & 35.588 \\
\hline 0.65 & 6.948 & 1.35 & 36.475 & $\begin{array}{l}0.55 \\
0.50\end{array}$ & $\begin{array}{l}4.753 \\
3.832\end{array}$ & 1.20 & 33.936 \\
\hline 0.60 & 5.869 & 1.30 & 34.832 & 0.45 & $\begin{array}{l}0.000 \\
2.800\end{array}$ & 1. 15 & 32. 313 \\
\hline 0.55 & 4. 391 & 1.25 & 33.241 & & & 1.10 & 30.733 \\
\hline 0.50 & 3.536 & 1. 20 & 31.695 & $\mathrm{H}_{2} /$ & 3.90 & 1.05 & 29. 172 \\
\hline 0.45 & 2.581 & $\begin{array}{l}1.15 \\
1.10\end{array}$ & $\begin{array}{l}30.185 \\
28.703\end{array}$ & $\begin{array}{l}1.80 \\
1.75\end{array}$ & $\begin{array}{l}60.520 \\
57.104\end{array}$ & $\begin{array}{l}1.00 \\
0.95\end{array}$ & $\begin{array}{l}27.633 \\
26.112\end{array}$ \\
\hline $\mathrm{H}_{2} /$ & 3.60 & 1.05 & 27.245 & 1.70 & 53.890 & 0.90 & 24.603 \\
\hline $\begin{array}{l}1.80 \\
1.75\end{array}$ & $\begin{array}{l}56.147 \\
53.072\end{array}$ & $\begin{array}{l}1.00 \\
0.95\end{array}$ & $\begin{array}{l}25.807 \\
24.386\end{array}$ & $\begin{array}{l}1.65 \\
1.60\end{array}$ & $\begin{array}{l}50.986 \\
48.379\end{array}$ & $\begin{array}{l}0.85 \\
0.80\end{array}$ & 19.201 \\
\hline 1.70 & 50.159 & 0.90 & 22.975 & 1.55 & 46.025 & 0.75 & 15. 493 \\
\hline 1.65 & 47.493 & 0.85 & 20.890 & 1.50 & 43.866 & $\begin{array}{l}0.70 \\
0.65\end{array}$ & $\begin{array}{r}11.407 \\
7.884\end{array}$ \\
\hline 1.60 & 45.084 & 0.80 & & 1.45 & 41.868 & 0.65 & \\
\hline 1.55 & 42.907 & 0.75 & 14.337 & 1.40 & 39.984 & 0.60 & 6.092 \\
\hline 1.50 & 40.910 & 0.70 & $\begin{array}{r}10.569 \\
7.323\end{array}$ & 1.35 & 38.190 & $\begin{array}{l}0.55 \\
0.50\end{array}$ & $\begin{array}{l}4.992 \\
4.028\end{array}$ \\
\hline 1.45 & $\begin{array}{l}39.043 \\
37.287\end{array}$ & & 7.323 & 1.30 & 36.475 & 0.50 & 4.028 \\
\hline 1.40 & 37.287 & 0.60 & 5.659 & 1.25 & 34.810 & 0.45 & 2.946 \\
\hline 1. 35 & 35.619 & $\begin{array}{l}0.55 \\
0.50\end{array}$ & $\begin{array}{l}4.632 \\
3.733\end{array}$ & 1.20 & 33.186 & & \\
\hline $\begin{array}{l}1.30 \\
1.25\end{array}$ & $\begin{array}{l}34.015 \\
32.457\end{array}$ & 0.45 & $\begin{array}{l}3.735 \\
2.727\end{array}$ & $\begin{array}{l}1.15 \\
1.10\end{array}$ & $\begin{array}{l}31.602 \\
30.055\end{array}$ & & \\
\hline 1.20 & & $\mathrm{H}_{2} / \mathrm{H}$ & 3.80 & & & & \\
\hline 1.15 & 29.471 & 1.80 & 59.054 & 1.00 & 27.025 & & \\
\hline
\end{tabular}


Table 15

Theoretical relationship between the group velocity (U) and the period $(\mathrm{T})$ for the case of [liquid-solid-solid] structure.

when: $\rho_{2} / \rho_{1}=1.80 \quad \rho_{3} / \rho_{1}=2.70 \quad \mathrm{C}_{2} / \mathrm{C}_{1}=0.69 \quad \mathrm{C}_{2 S} / \mathrm{C}_{1}=0.40 \quad \mathrm{C}_{3} / \mathrm{C}_{1}=3.60 \quad \mathrm{C}_{3 S} / \mathrm{C}_{1}=2.00$

Fundamental mode

\begin{tabular}{|c|c|c|c|c|c|}
\hline $\mathrm{U}$ & $\mathrm{km} / \mathrm{sec}$ & sec. & $\mathrm{U}$ & $\mathrm{km} / \mathrm{sec}$ & $\mathrm{T}$ sec. \\
\hline \multicolumn{3}{|c|}{$\mathrm{H}_{2} / \mathrm{H}_{1}=3.70$} & \multicolumn{3}{|c|}{$\mathrm{H}_{2} / \mathrm{H}_{1}=4.00$} \\
\hline & 0.147 & 1.64 & & 0.540 & 1.89 \\
\hline & 0.150 & 1.66 & & 0.705 & 2.06 \\
\hline & 0.666 & 1.81 & & 0.663 & 2.21 \\
\hline & 0.683 & 1.98 & & 0.638 & 2.33 \\
\hline & 0.650 & 2.11 & & 0.630 & 2.43 \\
\hline & 0.630 & 2.21 & & 0.651 & 2.51 \\
\hline & 0.645 & 2.30 & & 0.750 & 2.59 \\
\hline & 0.731 & 2.39 & & 0.930 & 2.68 \\
\hline & 0.903 & 2.48 & & 1.185 & 2.79 \\
\hline & 1.173 & 2.57 & & 1.485 & 2.90 \\
\hline & 1.506 & 2.69 & & 1.755 & 3.03 \\
\hline & 1. 791 & 2.82 & & 1.965 & 3.17 \\
\hline
\end{tabular}

Higher mode

\begin{tabular}{|c|c|c|c|c|c|c|c|}
\hline U & $\mathrm{km} / \mathrm{sec}$ & $T$ & sec. & $\mathrm{U}$ & $\mathrm{km} / \mathrm{sec}$ & $\mathrm{T}$ & sec. \\
\hline \multicolumn{4}{|c|}{$\mathrm{H}_{2} / \mathrm{H}_{1}=3.70$} & \multicolumn{4}{|c|}{$\mathrm{H}_{2} / \mathrm{H}_{1}=4.00$} \\
\hline & 0.608 & & 0.59 & & 0.510 & & 0.61 \\
\hline & 0.810 & & 0.96 & & 0.765 & & 0.98 \\
\hline & 0.825 & & 1.32 & & 0.840 & & 1.35 \\
\hline & 0.693 & & 1.60 & & 0.765 & & 1.65 \\
\hline & 0.176 & & 1.72 & & 0.375 & & 1.75 \\
\hline & 0.180 & & 1.76 & & 0.165 & & 1.87 \\
\hline & 0.345 & & 1.79 & & 0.270 & & 1.90 \\
\hline & 0.563 & & 1.83 & & 0.435 & & 1.94 \\
\hline & 0.855 & & 1.90 & & 0.668 & & 1.99 \\
\hline & 1.155 & & 1.99 & & 1.005 & & 2.07 \\
\hline & & & & & 1.230 & & 2.16 \\
\hline
\end{tabular}




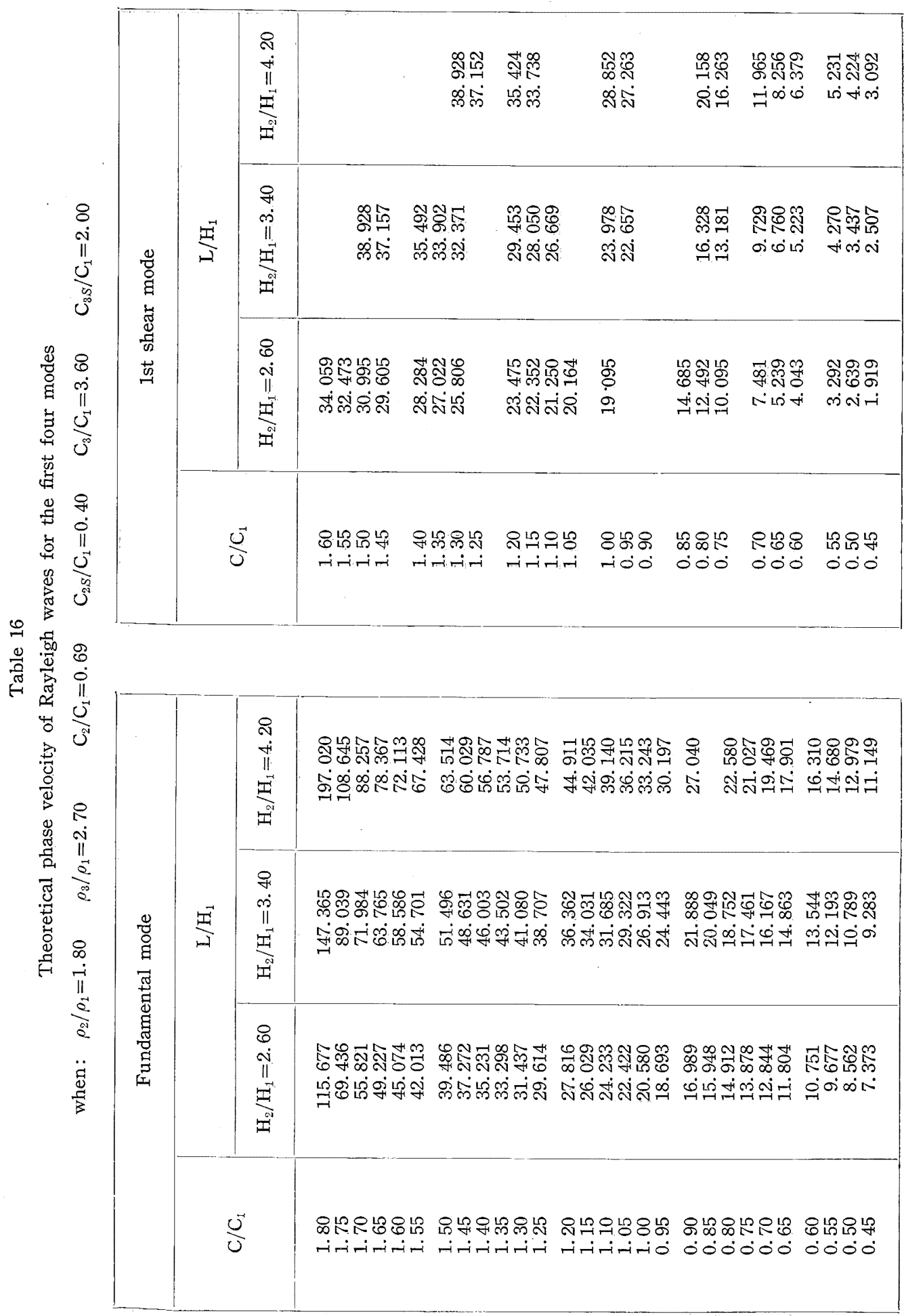




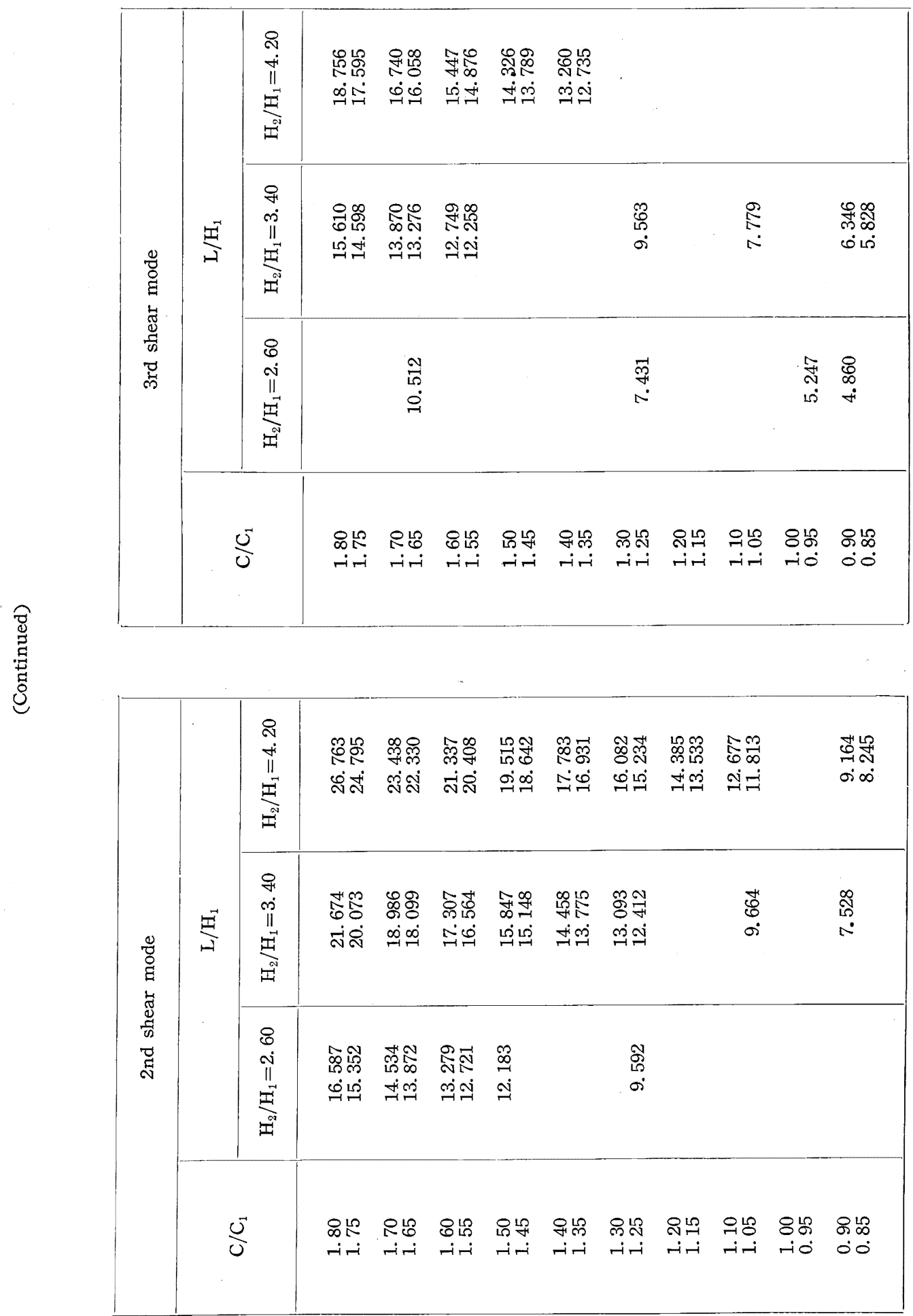


Table 17

Theoretical phase velocity of Rayleigh waves for the case of [liquid-solid-solid] structure (a) Fundamental mode

when: $\rho_{2} / \rho_{1}=1.80 \quad \rho_{3} / \rho_{1}=2.70 \quad \mathrm{C}_{2} / \mathrm{C}_{1}=1.20 \quad \mathrm{C}_{2 S} / \mathrm{C}_{1}=0.33 \quad \mathrm{C}_{3} / \mathrm{C}_{1}=3.60 \quad \mathrm{C}_{3 S} / \mathrm{C}_{1}=2.00$

\begin{tabular}{|c|c|c|c|c|c|c|c|}
\hline $\mathrm{C} / \mathrm{C}_{1}$ & $\mathrm{~L} / \mathrm{H}_{1}$ & $\mathrm{C} / \mathrm{C}_{1}$ & $\mathrm{~L} / \mathrm{H}_{1}$ & $\mathrm{C} / \mathrm{C}_{1}$ & $\mathrm{~L} / \mathrm{H}_{1}$ & $\mathrm{C} / \mathrm{C}_{1}$ & $\mathrm{~L} / \mathrm{H}_{1}$ \\
\hline \multicolumn{2}{|c|}{$\mathrm{H}_{2} / \mathrm{H}_{1}=0.20$} & 0.75 & $\begin{array}{l}7.097 \\
6.435\end{array}$ & \multirow{3}{*}{$\begin{array}{l}1.15 \\
1.10 \\
1.05 \\
1.00\end{array}$} & \multirow{3}{*}{$\begin{array}{l}31.517 \\
29.603 \\
27.687 \\
25.775\end{array}$} & \multirow{3}{*}{$\begin{array}{l}1.55 \\
1.50 \\
1.45 \\
1.40\end{array}$} & \multirow{3}{*}{$\begin{array}{l}76.722 \\
73.096 \\
69.677 \\
66.370\end{array}$} \\
\hline \multirow{4}{*}{$\begin{array}{l}1.80 \\
1.75 \\
1.70 \\
1.65\end{array}$} & 21.408 & 0.65 & 5.786 & & & & \\
\hline & 12.044 & 0.60 & 5.154 & & & & \\
\hline & $\begin{array}{l}9.342 \\
8.056\end{array}$ & \multirow{3}{*}{$\begin{array}{l}0.55 \\
0.50 \\
0.45 \\
0.40\end{array}$} & 4. 542 & \multirow{3}{*}{$\begin{array}{l}0.95 \\
0.90 \\
0.85 \\
0.80\end{array}$} & 23.866 & \multirow{3}{*}{$\begin{array}{l}1.35 \\
1.30 \\
1.25 \\
1.20\end{array}$} & \multirow{3}{*}{$\begin{array}{l}63.115 \\
59.940 \\
56.767 \\
53.625\end{array}$} \\
\hline & \multirow{3}{*}{$\begin{array}{l}7.254 \\
6.662 \\
6.177 \\
5.753\end{array}$} & & $\begin{array}{l}3.952 \\
3.381\end{array}$ & & $\begin{array}{l}21.963 \\
20.082\end{array}$ & & \\
\hline \multirow{2}{*}{$\begin{array}{l}1.60 \\
1.55 \\
1.50 \\
1.45\end{array}$} & & & 2.816 & & 18.240 & & \\
\hline & & \multicolumn{2}{|c|}{$\mathrm{H}_{2} / \mathrm{H}_{1}=1.80$} & $\begin{array}{l}0.75 \\
0.70\end{array}$ & $\begin{array}{l}16.460 \\
14.774\end{array}$ & \multirow{3}{*}{$\begin{array}{l}1.15 \\
1.10 \\
1.05 \\
1.00\end{array}$} & \multirow{3}{*}{$\begin{array}{l}50.478 \\
47.343 \\
44.183 \\
41.027\end{array}$} \\
\hline \multirow{3}{*}{$\begin{array}{l}1.40 \\
1.35 \\
1.30 \\
1.25\end{array}$} & \multirow{3}{*}{$\begin{array}{l}5.364 \\
5.000 \\
4.651 \\
4.314\end{array}$} & 1.80 & 79.094 & 0.65 & 13.203 & & \\
\hline & & 1.75 & 46.831 & 0.60 & 11.759 & & \\
\hline & & $\begin{array}{l}1.70 \\
1.65\end{array}$ & $\begin{array}{l}39.675 \\
36.657\end{array}$ & \multirow{3}{*}{$\begin{array}{l}0.55 \\
0.50 \\
0.45 \\
0.40\end{array}$} & $\begin{array}{r}10.432 \\
0.193\end{array}$ & \multirow{3}{*}{$\begin{array}{l}0.95 \\
0.90 \\
0.85 \\
0.80\end{array}$} & \multirow[t]{3}{*}{37.860} \\
\hline \multirow{3}{*}{$\begin{array}{l}1.20 \\
1.15 \\
1.10 \\
1.05\end{array}$} & \multirow{3}{*}{$\begin{array}{l}3.986 \\
3.667 \\
3.359 \\
3.064\end{array}$} & \multirow{3}{*}{$\begin{array}{l}1.60 \\
1.55 \\
1.50 \\
1.45\end{array}$} & \multirow{3}{*}{$\begin{array}{l}34.638 \\
32.966 \\
31.458 \\
30.026\end{array}$} & & 7.999 & & \\
\hline & & & & & 6.788 & & \\
\hline & & & & $\mathrm{H}_{2} /$ & $=3.40$ & $\begin{array}{l}0.75 \\
0.70\end{array}$ & $\begin{array}{l}25.543 \\
22.782\end{array}$ \\
\hline 1.00 & 2.785 & 1.40 & 28.648 & 1.80 & 140.296 & 0.65 & 20.262 \\
\hline 0.95 & $\begin{array}{l}2.525 \\
2.284\end{array}$ & 1.35 & 27.301 & 1.75 & 86.922 & 0.60 & 18.001 \\
\hline $\begin{array}{l}0.90 \\
0.85\end{array}$ & $\begin{array}{l}2.284 \\
2.060\end{array}$ & $\begin{array}{l}1.30 \\
1.25\end{array}$ & $\begin{array}{l}25.970 \\
24.653\end{array}$ & $\begin{array}{l}1.70 \\
1.65\end{array}$ & $\begin{array}{l}74.831 \\
69.257\end{array}$ & $\begin{array}{l}0.55 \\
0.50\end{array}$ & $\begin{array}{l}15.962 \\
14.079\end{array}$ \\
\hline 0.80 & 1.850 & 1.20 & 23.729 & 1.60 & 65.372 & 0.45 & 12.266 \\
\hline $\begin{array}{l}0.75 \\
0.70\end{array}$ & $\begin{array}{l}1.652 \\
1.465\end{array}$ & 1.15 & 22.041 & $\begin{array}{l}1.55 \\
1.50\end{array}$ & 62.140 & 0.40 & 10.409 \\
\hline 0.65 & 1.286 & $\begin{array}{l}1.10 \\
1.05\end{array}$ & $\begin{array}{l}20.740 \\
19.443\end{array}$ & 1.45 & $\begin{array}{l}59.212 \\
56.448\end{array}$ & $\mathrm{H}_{2} /$ & $=5.00$ \\
\hline 0.60 & 1. 118 & 1.00 & 18. 147 & 1.40 & 53.786 & 1.80 & 201.945 \\
\hline 0.55 & 0.962 & 0.95 & 16.857 & 1.35 & 51.185 & 1.75 & 127.204 \\
\hline 0.50 & 0.817 & 0.90 & 15.574 & 1.30 & 48.617 & 1.70 & 109.982 \\
\hline $\begin{array}{l}0.45 \\
0.40\end{array}$ & $\begin{array}{l}0.670 \\
0.657\end{array}$ & 0.85 & 14.306 & 1.25 & 46.068 & 1. 65 & 101.835 \\
\hline & 0.056 & 0.80 & 13.061 & 1.20 & 43.525 & 1.60 & 96.115 \\
\hline $\mathrm{H}_{2} /$ & 1.00 & $\begin{array}{l}0.75 \\
0.70\end{array}$ & $\begin{array}{l}11.851 \\
10.689\end{array}$ & $\begin{array}{l}1.15 \\
1.10\end{array}$ & $\begin{array}{l}40.996 \\
38.466\end{array}$ & 1.55 & 91.313 \\
\hline 1.80 & 49.048 & 0.65 & $\begin{array}{r}9.587 \\
. \quad 9\end{array}$ & 1.05 & 35.940 & 1.45 & 82.890 \\
\hline $\begin{array}{l}1.75 \\
1.70\end{array}$ & $\begin{array}{l}27.207 \\
22.145\end{array}$ & 0.60 & 8.551 & 1.00 & 33.402 & $\begin{array}{l}1.40 \\
1.25\end{array}$ & 78.944 \\
\hline 1.65 & 20.368 & $\begin{array}{l}0.55 \\
0.50\end{array}$ & 7.581 & 0.95 & 30.864 & 1.35 & 75.075 \\
\hline 1.60 & 19.283 & 0.45 & $\begin{array}{l}6.664 \\
5.777\end{array}$ & $\begin{array}{l}0.90 \\
0.85\end{array}$ & $\begin{array}{l}28.336 \\
25.828\end{array}$ & $\begin{array}{l}1.30 \\
1.25\end{array}$ & $\begin{array}{l}71.251 \\
67.484\end{array}$ \\
\hline 1.55 & 18. 405 & 0.40 & 4.880 & 0.80 & 23.377 & 1. 20 & $\begin{array}{l}07.484 \\
63.715\end{array}$ \\
\hline 1.45 & 16.850 & $\mathrm{H}_{2} / \mathrm{L}$ & 2.60 & $\begin{array}{l}0.75 \\
0.70\end{array}$ & $\begin{array}{l}21.016 \\
18.794\end{array}$ & $\begin{array}{l}1.15 \\
1.10\end{array}$ & $\begin{array}{l}59.962 \\
56.211\end{array}$ \\
\hline 1.40 & 16.118 & 1.80 & 109.607 & 0.65 & 16.750 & 1.05 & 52.436 \\
\hline 1.35 & 15. 397 & 1.75 & 66.839 & 0.60 & 14.896 & 1.00 & 48.646 \\
\hline 1. 30 & 14. 687 & 1.70 & 57.252 & 0.55 & 13.213 & 0.95 & 44.848 \\
\hline 1.25 & 13.983 & 1.65 & 52.954 & 0.50 & 11.652 & $\begin{array}{l}0.90 \\
0.85\end{array}$ & $\begin{array}{l}41.059 \\
37.289\end{array}$ \\
\hline 1. 20 & 13. 447 & 1. 60 & 50.007 & 0.45 & & 0.80 & 33.597 \\
\hline $\begin{array}{l}1.15 \\
1.10\end{array}$ & $\begin{array}{l}12.586 \\
11.892\end{array}$ & $\begin{array}{l}1.55 \\
1.50\end{array}$ & $\begin{array}{l}47.553 \\
45.328\end{array}$ & 0.40 & 8.618 & 0.75 & 30.056 \\
\hline 1.05 & 11. 199 & 1.45 & 43.233 & $\mathrm{H}_{2} / \mathrm{l}$ & $=4.20$ & $\begin{array}{l}0.70 \\
0.65\end{array}$ & $\begin{array}{l}26.751 \\
23.758\end{array}$ \\
\hline 1.00 & 10.507 & 1. 40 & 41.217 & 1.80 & 171.025 & 0.60 & 21.087 \\
\hline 0.95 & $\begin{array}{l}9.818 \\
9.131\end{array}$ & 1. 35 & 39.236 & 1.75 & 107.054 & 0.55 & 18.694 \\
\hline $\begin{array}{l}0.90 \\
0.85\end{array}$ & $\begin{array}{l}9.131 \\
8.448\end{array}$ & 1. 30 & 37.289 & 1.70 & 92.415 & 0.50 & 16.490 \\
\hline 0.80 & 7.769 & $\begin{array}{l}1.25 \\
1.20\end{array}$ & $\begin{array}{l}35.355 \\
33.430\end{array}$ & $\begin{array}{l}1.65 \\
1.60\end{array}$ & $\begin{array}{l}85.535 \\
80.727\end{array}$ & $\begin{array}{l}0.45 \\
0.40\end{array}$ & $\begin{array}{l}14.365 \\
12.180\end{array}$ \\
\hline
\end{tabular}


(b) Higher mode

when: $\rho_{2} / \rho_{1}=1.80 \quad \rho_{3} / \rho_{1}=2.70 \quad \mathrm{C}_{2} / \mathrm{C}_{1}=1.20 \quad \mathrm{C}_{2 S} / \mathrm{C}_{1}=0.33 \quad \mathrm{C}_{3} / \mathrm{C}_{1}=3.60 \quad \mathrm{C}_{3 S} / \mathrm{C}_{1}=2.00$

\begin{tabular}{|c|c|c|c|c|c|c|c|}
\hline $\mathrm{C} / \mathrm{C}_{1}$ & $\mathrm{~L} / \mathrm{H}_{1}$ & $\mathrm{C} / \mathrm{C}_{1}$ & $\mathrm{~L} / \mathrm{H}_{1}$ & $\mathrm{C} / \mathrm{C}_{1}$ & $\mathrm{~L} / \mathrm{H}_{1}$ & $\mathrm{C} / \mathrm{C}_{1}$ & $\mathrm{~L} / \mathrm{H}_{1}$ \\
\hline \multicolumn{2}{|c|}{$\mathrm{H}_{2} / \mathrm{H}_{1}=0.20$} & \multirow{3}{*}{$\begin{array}{l}0.75 \\
0.70 \\
0.65 \\
0.60\end{array}$} & \multirow{3}{*}{$\begin{array}{l}3.040 \\
2.719 \\
2.393 \\
2.067\end{array}$} & \multirow{3}{*}{$\begin{array}{l}1.15 \\
1.10 \\
1.05 \\
1.00\end{array}$} & \multirow{3}{*}{$\begin{array}{l}14.312 \\
13.538 \\
12.764 \\
11.982\end{array}$} & \multirow{3}{*}{$\begin{array}{l}1.55 \\
1.50 \\
1.45 \\
1.40\end{array}$} & \multirow{3}{*}{$\begin{array}{l}34.079 \\
32.113 \\
30.476 \\
29.035\end{array}$} \\
\hline 1.80 & 5.197 & & & & & & \\
\hline 1.75 & 4.733 & & & & & & \\
\hline $\begin{array}{l}1.70 \\
1.65\end{array}$ & $\begin{array}{l}4.366 \\
4.072\end{array}$ & \multirow{3}{*}{$\begin{array}{l}0.55 \\
0.50 \\
0.45 \\
0.40\end{array}$} & \multirow{3}{*}{$\begin{array}{l}1.750 \\
1.451 \\
1.169 \\
0.883\end{array}$} & \multirow{3}{*}{$\begin{array}{l}0.95 \\
0.90 \\
0.85 \\
0.80\end{array}$} & \multirow{3}{*}{$\begin{array}{r}11.188 \\
10.376 \\
9.546 \\
8.694\end{array}$} & \multirow{3}{*}{$\begin{array}{l}1.35 \\
1.30 \\
1.25 \\
1.20\end{array}$} & \multirow{3}{*}{$\begin{array}{l}27.709 \\
26.452 \\
25.244 \\
24.054\end{array}$} \\
\hline 1.60 & 3.823 & & & & & & \\
\hline 1.55 & 3. 601 & & & & & & \\
\hline $\begin{array}{l}1.50 \\
1.45\end{array}$ & $\begin{array}{l}3.393 \\
3.193\end{array}$ & \multicolumn{2}{|c|}{$\mathrm{H}_{2} / \mathrm{H}_{1}=1.80$} & \multirow{3}{*}{$\begin{array}{l}0.75 \\
0.70 \\
0.65 \\
0.60\end{array}$} & $\begin{array}{l}7.826 \\
6.954\end{array}$ & \multirow{3}{*}{$\begin{array}{l}1.15 \\
1.10 \\
1.05 \\
1.00\end{array}$} & \multirow{3}{*}{$\begin{array}{l}22.877 \\
21.698 \\
20.511 \\
19.298\end{array}$} \\
\hline 1. 40 & 2.995 & 1.80 & 33. 147 & & 6.092 & & \\
\hline $\begin{array}{l}1.35 \\
1.30\end{array}$ & $\begin{array}{l}2.795 \\
2.588\end{array}$ & 1.75 & 28.178 & & 5.259 & & \\
\hline $\begin{array}{l}1.30 \\
1.25\end{array}$ & $\begin{array}{l}2.588 \\
2.369\end{array}$ & $\begin{array}{l}1.70 \\
1.65\end{array}$ & $\begin{array}{l}23.245 \\
19.942\end{array}$ & \multirow{3}{*}{$\begin{array}{l}0.55 \\
0.50 \\
0.45 \\
0.40\end{array}$} & \multirow{3}{*}{$\begin{array}{l}4.472 \\
3.734 \\
3.028 \\
2.293\end{array}$} & \multirow{3}{*}{$\begin{array}{l}0.95 \\
0.90 \\
0.85 \\
0.80\end{array}$} & \multirow[t]{3}{*}{18.053} \\
\hline 1.20 & 2. 128 & 1.60 & 17.774 & & & & \\
\hline 1.15 & $\begin{array}{l}1.854 \\
1.526\end{array}$ & 1.55 & 16. 238 & & & & \\
\hline 1.05 & 1.147 & $\begin{array}{l}1.50 \\
1.45\end{array}$ & $\begin{array}{l}15.063 \\
14.104\end{array}$ & \multicolumn{2}{|c|}{$\mathrm{H}_{2} / \mathrm{H}_{1}=3.40$} & \multirow{3}{*}{$\begin{array}{l}0.75 \\
0.70 \\
0.65 \\
0.60\end{array}$} & \multirow{3}{*}{$\begin{array}{r}12.557 \\
11.087 \\
9.651 \\
8.300\end{array}$} \\
\hline 1.00 & 0.951 & 1.40 & 13.280 & 1.80 & 58.538 & & \\
\hline 0.95 & 0.866 & 1.35 & 12.544 & 1.75 & 47.521 & & \\
\hline $\begin{array}{l}0.90 \\
0.85\end{array}$ & $\begin{array}{l}0.798 \\
0.734\end{array}$ & $\begin{array}{l}1.30 \\
1.25\end{array}$ & $\begin{array}{l}11.867 \\
11.231\end{array}$ & $\begin{array}{l}1.70 \\
1.65\end{array}$ & $\begin{array}{l}38.779 \\
33.546\end{array}$ & $\begin{array}{l}0.55 \\
0.50\end{array}$ & $\begin{array}{l}7.060 \\
5.922\end{array}$ \\
\hline 0.80 & 0.669 & 1.20 & & 1.60 & 30.298 & 0.45 & 4. 834 \\
\hline $\begin{array}{l}0.75 \\
0.70\end{array}$ & & 1.15 & 10.033 & 1.55 & 28. 067 & 0.40 & 3.685 \\
\hline 0.65 & & $\begin{array}{l}1.10 \\
1.05\end{array}$ & $\begin{array}{l}9.456 \\
8.887\end{array}$ & 1.45 & $\begin{array}{l}26.374 \\
24.973\end{array}$ & $\mathrm{H}_{2} /$ & 5.00 \\
\hline 0.60 & & 1.00 & 8.320 & 1.40 & 23. 749 & 1.80 & 83.655 \\
\hline 0.55 & & 0.95 & 7.754 & 1.35 & 22.630 & 1.75 & 66.804 \\
\hline $\begin{array}{l}0.50 \\
0.45\end{array}$ & & 0.90 & 7.184 & 1.30 & 21.573 & 1.70 & 54.455 \\
\hline $\begin{array}{l}0.45 \\
0.40\end{array}$ & & 0.85 & 6.610 & 1.25 & 20.561 & 1.65 & $\begin{array}{l}47.353 \\
43.045\end{array}$ \\
\hline $\mathrm{H}_{2} /$ & 1.00 & $\begin{array}{l}0.80 \\
0.75\end{array}$ & $\begin{array}{l}6.030 \\
5.444\end{array}$ & $\begin{array}{l}1.20 \\
1.15\end{array}$ & $\begin{array}{l}19.571 \\
18.595\end{array}$ & 1.55 & 40.104 \\
\hline 1.80 & 20.024 & $\begin{array}{l}0.70 \\
0.65\end{array}$ & $\begin{array}{l}4.855 \\
4.267\end{array}$ & $\begin{array}{l}1.10 \\
1.05\end{array}$ & $\begin{array}{l}17.620 \\
16.637\end{array}$ & $\begin{array}{l}1.50 \\
1.45\end{array}$ & $\begin{array}{l}37.866 \\
35.994\end{array}$ \\
\hline 1.75 & 18.255 & 0.60 & 3.688 & 1.00 & 15.641 & 1.40 & 34. 334 \\
\hline $\begin{array}{l}1.70 \\
1.65\end{array}$ & $\begin{array}{l}15.683 \\
13.455\end{array}$ & 0.55 & 3. 131 & 0.95 & 14.620 & 1.35 & 32.794 \\
\hline & & 0.50 & 2.604 & 0.90 & 13.569 & 1.30 & 31. 337 \\
\hline $\begin{array}{l}1.60 \\
1.55\end{array}$ & $\begin{array}{l}11.866 \\
10.690\end{array}$ & 0.45 & 2. 104 & 0.85 & 12.480 & 1.25 & 29.926 \\
\hline $\begin{array}{l}1.55 \\
1.50\end{array}$ & $\begin{array}{r}10.690 \\
9.760\end{array}$ & 0.40 & 1.589 & 0.80 & 11. 354 & 1.20 & $\begin{array}{l}28.540 \\
27.162\end{array}$ \\
\hline 1.45 & 8.984 & $\mathrm{H}_{2} /$ & 2.60 & $\begin{array}{l}0.75 \\
0.70\end{array}$ & $\begin{array}{r}10.196 \\
9.029\end{array}$ & 1.10 & 25.782 \\
\hline 1. 40 & 8. 311 & 1.80 & 45.907 & 0.65 & 7.883 & 1.05 & 24. 383 \\
\hline $\begin{array}{l}1.35 \\
1.30\end{array}$ & $\begin{array}{l}7.711 \\
7.165\end{array}$ & 1.75 & 37.866 & 0.60 & 6.793 & 1.00 & 22.956 \\
\hline $\begin{array}{l}1.20 \\
1.25\end{array}$ & $\begin{array}{l}6.105 \\
6.664\end{array}$ & 1.70 & 30.981 & 0.55 & 5. 779 & $\begin{array}{l}0.95 \\
0.90\end{array}$ & $\begin{array}{l}21.484 \\
19.954\end{array}$ \\
\hline 1.20 & & 160 & 26. 698 & $\begin{array}{l}0.50 \\
0.45\end{array}$ & $\begin{array}{l}4.839 \\
3.938\end{array}$ & 0.85 & 18. 349 \\
\hline 1.15 & 5. 774 & $\begin{array}{l}1.60 \\
1.55\end{array}$ & $\begin{array}{l}23.983 \\
22.101\end{array}$ & 0.40 & 2.991 & 0.80 & 16.665 \\
\hline 1.10 & 5. 376 & 1.50 & 20.672 & & & 0.75 & 14. 913 \\
\hline 1.05 & 5.003 & 1.45 & 19.502 & $\mathrm{H}_{2} /$ & 4.20 & $\begin{array}{l}0.70 \\
0.65\end{array}$ & $\begin{array}{l}13.135 \\
11.404\end{array}$ \\
\hline $\begin{array}{l}1.00 \\
0.95\end{array}$ & $\begin{array}{l}4.652 \\
4.316\end{array}$ & 1.40 & 18. 484 & 1.80 & 71.116 & 0.60 & 9.789 \\
\hline 0.90 & 3. 992 & 1. 35 . & 17.564 & 1.75 & 57.165 & 0.55 & 8. 325 \\
\hline 0.85 & 3. 673 & $\begin{array}{l}1.30 \\
1.25\end{array}$ & $\begin{array}{l}16.705 \\
15.886\end{array}$ & $\begin{array}{l}1.70 \\
1.65\end{array}$ & $\begin{array}{l}46.612 \\
40.437\end{array}$ & $\begin{array}{l}0.50 \\
0.45\end{array}$ & $\begin{array}{l}6.991 \\
5.718\end{array}$ \\
\hline 0.80 & 3. 357 & 1.20 & 15.092 & 1.60 & 36.658 & 0.40 & 4. 369 \\
\hline
\end{tabular}


Table $18-$ (a)

Theoretical phase velocity of Rayleigh waves for the oceanic path

(a) when: $\rho_{2} / \rho_{1}=1.80 \quad \rho_{3} / \rho_{1}=3.00 \quad \mathrm{C}_{2} / \mathrm{C}_{1}=1.14 \quad \mathrm{C}_{2 S} / \mathrm{C}_{1}=0.66 \quad \mathrm{C}_{3} / \mathrm{C}_{1}=5.20 \quad \mathrm{C}_{3 S} / \mathrm{C}_{1}=3.00$

\begin{tabular}{|c|c|c|c|c|c|}
\hline $\mathrm{C} / \mathrm{C}_{1}$ & $\mathrm{~L} / \mathrm{H}_{1}$ & $\mathrm{C} / \mathrm{C}_{1}$ & $\mathrm{~L} / \mathrm{H}_{1}$ & $\mathrm{C} / \mathrm{C}_{1}$ & $\mathrm{~L} / \mathrm{H}_{1}$ \\
\hline \multicolumn{2}{|c|}{$\mathrm{H}_{2} / \mathrm{H}_{1}=0.10$} & \multicolumn{2}{|c|}{$\mathrm{H}_{2} / \mathrm{H}_{1}=0.20$} & \multicolumn{2}{|c|}{$\mathrm{H}_{2} / \mathrm{H}_{1}=0.30$} \\
\hline $\begin{array}{l}2.70 \\
2.65\end{array}$ & $\begin{array}{l}23.149 \\
16.008\end{array}$ & $\begin{array}{l}2.70 \\
2.65\end{array}$ & $\begin{array}{l}26.506 \\
17.615\end{array}$ & $\begin{array}{l}2.70 \\
2.65\end{array}$ & $\begin{array}{l}30.123 \\
19.426\end{array}$ \\
\hline $\begin{array}{l}2.60 \\
2.55\end{array}$ & $\begin{array}{l}13.642 \\
12.420\end{array}$ & $\begin{array}{l}2.60 \\
2.55\end{array}$ & $\begin{array}{l}14.720 \\
13.274\end{array}$ & $\begin{array}{l}2.60 \\
2.55\end{array}$ & $\begin{array}{l}15.936 \\
14.227\end{array}$ \\
\hline $\begin{array}{l}2.50 \\
2.45\end{array}$ & $\begin{array}{l}11.623 \\
11.028\end{array}$ & $\begin{array}{l}2.50 \\
2.45\end{array}$ & $\begin{array}{l}12.360 \\
11.692\end{array}$ & $\begin{array}{l}2.50 \\
2.45\end{array}$ & $\begin{array}{l}13.173 \\
12.419\end{array}$ \\
\hline $\begin{array}{l}2.40 \\
2.35\end{array}$ & $\begin{array}{l}10.541 \\
10.120\end{array}$ & $\begin{array}{l}2.40 \\
2.35\end{array}$ & $\begin{array}{l}11.157 \\
10.700\end{array}$ & $\begin{array}{l}2.40 \\
2.35\end{array}$ & $\begin{array}{l}11.826 \\
11.328\end{array}$ \\
\hline $\begin{array}{l}2.30 \\
2.25\end{array}$ & $\begin{array}{l}9.741 \\
9.391\end{array}$ & $\begin{array}{l}2.30 \\
2.25\end{array}$ & $\begin{array}{r}10.294 \\
9.921\end{array}$ & $\begin{array}{l}2.30 \\
2.25\end{array}$ & $\begin{array}{l}10.889 \\
10.490\end{array}$ \\
\hline $\begin{array}{l}2.20 \\
2.15\end{array}$ & $\begin{array}{l}9.061 \\
8.746\end{array}$ & $\begin{array}{l}2.20 \\
2.15\end{array}$ & $\begin{array}{l}9.572 \\
9.240\end{array}$ & $\begin{array}{l}2.20 \\
2.15\end{array}$ & $\begin{array}{r}10.119 \\
9.768\end{array}$ \\
\hline $\begin{array}{l}2.10 \\
2.05\end{array}$ & $\begin{array}{l}8.442 \\
8.146\end{array}$ & $\begin{array}{l}2.10 \\
2.05\end{array}$ & $\begin{array}{l}8.922 \\
8.612\end{array}$ & $\begin{array}{l}2.10 \\
2.05\end{array}$ & $\begin{array}{l}9.432 \\
9.108\end{array}$ \\
\hline $\begin{array}{l}2.00 \\
1.95\end{array}$ & $\begin{array}{l}7.857 \\
7.571\end{array}$ & $\begin{array}{l}2.00 \\
1.95\end{array}$ & $\begin{array}{l}8.310 \\
8.013\end{array}$ & $\begin{array}{l}2.00 \\
1.95\end{array}$ & $\begin{array}{l}8.792 \\
8.482\end{array}$ \\
\hline $\begin{array}{l}1.90 \\
1.85\end{array}$ & $\begin{array}{l}7.289 \\
7.009\end{array}$ & $\begin{array}{l}1.90 \\
1.85\end{array}$ & $\begin{array}{l}7.721 \\
7.431\end{array}$ & $\begin{array}{l}1.90 \\
1.85\end{array}$ & $\begin{array}{l}8.178 \\
7.877\end{array}$ \\
\hline $\begin{array}{l}1.80 \\
1.75\end{array}$ & $\begin{array}{l}6.730 \\
6.452\end{array}$ & $\begin{array}{l}1.80 \\
1.75\end{array}$ & $\begin{array}{l}7.143 \\
6.856\end{array}$ & $\begin{array}{l}1.80 \\
1.75\end{array}$ & $\begin{array}{l}7.579 \\
7.283\end{array}$ \\
\hline $\begin{array}{l}1.70 \\
1.65\end{array}$ & $\begin{array}{l}6.173 \\
5.894\end{array}$ & $\begin{array}{l}1.70 \\
1.65\end{array}$ & $\begin{array}{l}6.570 \\
6.284\end{array}$ & $\begin{array}{l}1.70 \\
1.65\end{array}$ & $\begin{array}{l}6.988 \\
6.694\end{array}$ \\
\hline $\begin{array}{l}1.60 \\
1.55\end{array}$ & $\begin{array}{l}5.612 \\
5.328\end{array}$ & $\begin{array}{l}1.60 \\
1.55\end{array}$ & $\begin{array}{l}5.996 \\
5.706\end{array}$ & $\begin{array}{l}1.60 \\
1.55\end{array}$ & $\begin{array}{l}6.399 \\
6.103\end{array}$ \\
\hline $\begin{array}{l}1.50 \\
1.45\end{array}$ & $\begin{array}{l}5.041 \\
4.749\end{array}$ & $\begin{array}{l}1.50 \\
1.45\end{array}$ & $\begin{array}{l}5.414 \\
5.119\end{array}$ & $\begin{array}{l}1.50 \\
1.45\end{array}$ & $\begin{array}{l}5.806 \\
5.506\end{array}$ \\
\hline $\begin{array}{l}1.40 \\
1.35\end{array}$ & $\begin{array}{l}\text { 4. } 451 \\
4.145\end{array}$ & $\begin{array}{l}1.40 \\
1.35\end{array}$ & $\begin{array}{l}4.819 \\
4.514\end{array}$ & $\begin{array}{l}1.40 \\
1.35\end{array}$ & $\begin{array}{l}5.204 \\
4.897\end{array}$ \\
\hline $\begin{array}{l}1.30^{\circ} \\
1.25\end{array}$ & $\begin{array}{l}3.830 \\
3.502\end{array}$ & $\begin{array}{l}1.30 \\
1.25\end{array}$ & $\begin{array}{l}4.201 \\
3.880\end{array}$ & $\begin{array}{l}\text { 1. } 30 \\
\text { 1. } 25\end{array}$ & $\begin{array}{l}4.585 \\
4.268\end{array}$ \\
\hline $\begin{array}{l}1.20 \\
1.15\end{array}$ & $\begin{array}{l}3.158 \\
2.792\end{array}$ & $\begin{array}{l}1.20 \\
1.15\end{array}$ & $\begin{array}{l}3.547 \\
3.200\end{array}$ & $\begin{array}{l}1.20 \\
1.15\end{array}$ & $\begin{array}{l}3.942 \\
3.609\end{array}$ \\
\hline $\begin{array}{l}1.10 \\
1.05\end{array}$ & $\begin{array}{l}2.393 \\
1.947\end{array}$ & $\begin{array}{l}1.10 \\
1.05\end{array}$ & $\begin{array}{l}2.835 \\
2.450\end{array}$ & $\begin{array}{l}1.10 \\
1.05\end{array}$ & $\begin{array}{l}3.265 \\
2.910\end{array}$ \\
\hline
\end{tabular}


Table $18-(b)$

Theoretical phase velocity of Rayleigh waves for the oceanic path

(b) when: $\rho_{2} / \rho_{1}=2.80 \quad \rho_{3} / \rho_{1}=3.00 \quad \mathrm{C}_{2} / \mathrm{C}_{1}=3.34 \quad \mathrm{C}_{2 S} / \mathrm{C}_{1}=1.93 \quad \mathrm{C}_{2} / \mathrm{C}_{1}=5.30 \quad \mathrm{C}_{3 S} / \mathrm{C}_{1}=3.04$

\begin{tabular}{|c|c|c|c|c|c|c|c|}
\hline $\mathrm{C} / \mathrm{C}_{1}$ & $\mathrm{~L} / \mathrm{H}_{1}$ & $\mathrm{C} / \mathrm{C}_{1}$ & $\mathrm{~L} / \mathrm{H}_{1}$ & $\mathrm{C} / \mathrm{C}_{1}$ & $\mathrm{~L} / \mathrm{H}_{1}$ & $\mathrm{C} / \mathrm{C}_{1}$ & $\mathrm{~L} / \mathrm{H}_{1}$ \\
\hline \multicolumn{2}{|c|}{$\mathrm{H}_{2} / \mathrm{H}_{1}=0.50$} & 1.45 & 4. 623 & \multirow{8}{*}{$\begin{array}{l}1.70 \\
1.65 \\
1.60 \\
1.55 \\
1.50 \\
1.45 \\
1.40 \\
1.35 \\
1.30 \\
1.25 \\
\end{array}$} & \multirow{8}{*}{$\begin{array}{l}6.495 \\
6.177 \\
5.859 \\
5.540 \\
5.218 \\
4.891 \\
4.557 \\
4.214 \\
3.859 \\
3.487\end{array}$} & \multirow{12}{*}{$\begin{array}{l}1.95 \\
1.90 \\
1.85 \\
1.80 \\
1.75 \\
1.70 \\
1.65 \\
1.60 \\
1.55 \\
1.50 \\
1.45 \\
1.40 \\
1.35 \\
1.30 \\
1.25\end{array}$} & \multirow{12}{*}{$\begin{array}{l}9.248 \\
8.780 \\
8.330 \\
7.895 \\
7.470 \\
7.055 \\
6.648 \\
6.246 \\
5.851 \\
5.459 \\
5.071 \\
4.686 \\
4.301 \\
3.912 \\
3.517\end{array}$} \\
\hline 2.70 & 22. 397 & 1.35 & 4.011 & & & & \\
\hline 2.65 & 16.403 & 1.30 & 3.689 & & & & \\
\hline 2.60 & 13.801 & 1.25 & 3.352 & & & & \\
\hline $\begin{array}{l}2.55 \\
2.50\end{array}$ & $\begin{array}{l}12.388 \\
11.481\end{array}$ & $\mathrm{H}_{2} / \mathrm{I}$ & 1.50 & & & & \\
\hline 2.45 & 10.822 & 2.70 & 41.633 & & & & \\
\hline 2.40 & 10.298 & 2.65 & 27.117 & & & & \\
\hline 2.35 & $\begin{array}{l}9.855 \\
9.464\end{array}$ & 2.60 & 20.242 & & & & \\
\hline $\begin{array}{l}2.30 \\
2.25\end{array}$ & $\begin{array}{l}9.464 \\
9.107\end{array}$ & $\begin{array}{l}2.55 \\
2.50\end{array}$ & $\begin{array}{l}16.466 \\
14.221\end{array}$ & \multicolumn{2}{|c|}{$\mathrm{H}_{2} / \mathrm{H}_{1}=2.50$} & & \\
\hline 2.20 & 8. 773 & 2.45 & 12.786 & \multirow{4}{*}{$\begin{array}{l}2.70 \\
2.65 \\
2.60 \\
2.55 \\
2.50\end{array}$} & \multirow{4}{*}{$\begin{array}{l}62.066 \\
39.481 \\
28.527 \\
22.350\end{array}$} & & \\
\hline $\begin{array}{l}2.15 \\
2.10\end{array}$ & $\begin{array}{l}8.457 \\
8.153\end{array}$ & 2.40 & 11.793 & & & & \\
\hline $\begin{array}{l}2.10 \\
2.05\end{array}$ & $\begin{array}{l}8.153 \\
7.858\end{array}$ & 2.35 & 11.050 & & & & \\
\hline 2.00 & 7.571 & $\begin{array}{l}2.30 \\
2.25\end{array}$ & $\begin{array}{r}10.457 \\
9.958\end{array}$ & & & \multicolumn{2}{|c|}{$\mathrm{H}_{2} / \mathrm{H}_{1}=3.50$} \\
\hline 1.95 & 7.288 & 2.20 & 9.520 & \multirow{4}{*}{$\begin{array}{l}2.45 \\
2.40 \\
2.35 \\
2.30\end{array}$} & \multirow{7}{*}{$\begin{array}{l}18.609 \\
16 \cdot 209 \\
14.565 \\
13.364 \\
12.433 \\
11.673 \\
11.028 \\
10.462\end{array}$} & \multirow{2}{*}{$\begin{array}{l}2.70 \\
2.65\end{array}$} & 82.659 \\
\hline $\begin{array}{l}1.90 \\
1.85\end{array}$ & $\begin{array}{l}7.009 \\
6.732\end{array}$ & 2.15 & 9.124 & & & & 52.133 \\
\hline $\begin{array}{l}1.85 \\
1.80\end{array}$ & $\begin{array}{l}6.732 \\
6.457\end{array}$ & 2.10 & 8.758 & & & \multirow{6}{*}{\multicolumn{2}{|c|}{\begin{tabular}{l|l}
2.60 & 37.257 \\
2.55 & 28.837 \\
2.50 & 23.740 \\
2.45 & 20.468 \\
2.40 & 18.222 \\
2.35 & 16.570 \\
2.30 & 15.281 \\
2.25 & 14.224
\end{tabular}}} \\
\hline $\begin{array}{l}1.80 \\
1.75\end{array}$ & $\begin{array}{l}6.457 \\
6.182\end{array}$ & 2.05 & 8.412 & & & & \\
\hline $\begin{array}{l}1.75 \\
1.70\end{array}$ & $\begin{array}{l}6.182 \\
5.907\end{array}$ & 2.00 & 8.082 & 2.25 & & & \\
\hline $\begin{array}{l}1.70 \\
1.65\end{array}$ & $\begin{array}{l}5.907 \\
5.630\end{array}$ & 1.95 & 7.764 & 2.20 & & & \\
\hline 1.60 & $\begin{array}{l}5.030 \\
5.352\end{array}$ & 1.90 & 7.454 & 2.15 & & & \\
\hline 1.55 & 5.070 & 1.85 & 7.150 & 2.10 & \multirow{2}{*}{$\begin{array}{l}9.953 \\
9.485\end{array}$} & \multirow{2}{*}{$\begin{array}{l}2.35 \\
2.30\end{array}$} & \\
\hline 1.50 & 4.784 & 1.80 & 6.850 & 2.05 & & & \\
\hline 1.45 & 4.493 & 1.75 & 6.554 & 2.00 & \multirow{2}{*}{$\begin{array}{l}9.049 \\
8.625\end{array}$} & & \\
\hline 1.40 & 4. 196 & 1.70 & 6.238 & 1.95 & & \multirow{2}{*}{$\begin{array}{l}2.20 \\
2.15\end{array}$} & \multirow{5}{*}{$\begin{array}{r}13.273 \\
12.531 \\
11.816 \\
11.159 \\
10.545 \\
9.963 \\
9.408\end{array}$} \\
\hline 1.35 & 3.889 & 1.65 & 5.963 & 1.90 & 8.240 & & \\
\hline 1.30 & 3.571 & $\begin{array}{l}1.60 \\
1.55\end{array}$ & 5. 668 & 1.85 & 7.858 & 2.10 & \\
\hline 1.25 & 3.238 & $\begin{array}{l}1.55 \\
1.50\end{array}$ & $\begin{array}{l}5.370 \\
5.068\end{array}$ & $\begin{array}{l}1.80 \\
1.75\end{array}$ & $\begin{array}{l}7.486 \\
7.122\end{array}$ & $\begin{array}{l}2.05 \\
2.00\end{array}$ & \\
\hline $\mathrm{H}_{2} /$ & 00 & $\begin{array}{l}1.45 \\
1.40\end{array}$ & 4.762 & 1.70 & 6.764 & 1.95 & \\
\hline & & 1.35 & $\begin{array}{l}4.440 \\
4.126\end{array}$ & $\begin{array}{l}1.05 \\
1.60\end{array}$ & $\begin{array}{l}0.405 \\
6.056\end{array}$ & $\begin{array}{l}1.90 \\
1.85\end{array}$ & $\begin{array}{l}9.408 \\
8.873\end{array}$ \\
\hline $\begin{array}{l}2.70 \\
2.65\end{array}$ & $\begin{array}{l}31.073 \\
21.331\end{array}$ & 1.30 & 3.791 & 1.55 & 5.704 & 1.80 & 8.354 \\
\hline 2.60 & 16.616 & 1.25 & 3.439 & 1.50 & 5. 351 & 1.75 & 7.850 \\
\hline $\begin{array}{l}2.55 \\
2.50\end{array}$ & $\begin{array}{l}14.106 \\
12.614\end{array}$ & $\mathrm{H}_{2} / \mathrm{l}$ & 2.00 & $\begin{array}{l}1.45 \\
1.40\end{array}$ & $\begin{array}{l}4.995 \\
4.636\end{array}$ & $\begin{array}{l}1.70 \\
1.65\end{array}$ & $\begin{array}{l}7.359 \\
6.883\end{array}$ \\
\hline 2.45 & 11.628 & 2.70 & 51.808 & 1.35 & 4.270 & 1.60 & 6.420 \\
\hline 2.40 & 10.910 & 2.65 & 33.231 & 1.30 & 3.896 & 1.55 & 5.972 \\
\hline 2.35 & 10.344 & 2.60 & 24.287 & 1.25 & 3.509 & 1.50 & 5.540 \\
\hline $\begin{array}{l}2.30 \\
2.25\end{array}$ & $\begin{array}{l}9.870 \\
9.456\end{array}$ & $\begin{array}{l}2.55 \\
2.50\end{array}$ & $\begin{array}{l}19.280 \\
16.266\end{array}$ & $\mathrm{H}_{2} /$ & 3.00 & $\begin{array}{l}1.40 \\
1.40\end{array}$ & $\begin{array}{l}5.121 \\
4.714\end{array}$ \\
\hline 2.20 & 9.080 & 2.45 & 14.339 & 2.70 & 72.342 & 1.35 & 4. 315 \\
\hline 2.15 & 8.732 & 2.40 & 13.021 & 2.65 & 45.789 & $\begin{array}{l}1.30 \\
1.25\end{array}$ & $\begin{array}{l}3.919 \\
3.520\end{array}$ \\
\hline 2.10 & 8.403 & 2.35 & 12.057 & 2.60 & 32.866 & & \\
\hline 2.05 & $\begin{array}{l}8.088 \\
7.784\end{array}$ & 2.30 & $\begin{array}{l}11.305 \\
10.688\end{array}$ & $\begin{array}{l}2.55 \\
2.50\end{array}$ & $\begin{array}{l}25.555 \\
21.125\end{array}$ & $\mathrm{H}_{2} /$ & 4.00 \\
\hline $\begin{array}{l}2.00 \\
1.95\end{array}$ & $\begin{array}{l}7.784 \\
7.488\end{array}$ & $\begin{array}{l}2.25 \\
2.20\end{array}$ & 10.159 & 2.45 & 18. 280 & 2.70 & .92 .993 \\
\hline 1.90 & 7.197 & 2.15 & 9.691 & 2.40 & 16.328 & 2.65 & 58.497 \\
\hline 1. 85 & 6.910 & 2.10 & 9.265 & 2.35 & 14.896 & 2.60 & 41.674 \\
\hline 1.80 & 6.626 & 2.05 & 8.869 & 2.30 & 13.783 & 2.55 & 32.163 \\
\hline 1.75 & 6.344 & 2.00 & 8.496 & 2.25 & 12.874 & 2.50 & 26.410 \\
\hline 1.70 & 6.062 & 1.95 & 8. 141 & 2.20 & 12.101 & 2.45 & 22.725 \\
\hline 1.65 & 5.779 & 1.90 & 7.797 & 2.15 & 11.424 & 2.40 & 20.195 \\
\hline 1.60 & 5.495 & 1.85 & 7.463 & 2.10 & 10.816 & 2.35 & 18. 329 \\
\hline 1.55 & 5.208 & 1.80 & 7.136 & 2.05 & 10.258 & 2.30 & 16. 869 \\
\hline 1.50 & 4.918 & 1.75 & 6.814 & 2.00 & 9.738 & 2.25 & 15.669 \\
\hline
\end{tabular}


(Continued)

\begin{tabular}{|c|c|c|c|c|c|c|c|}
\hline $\mathrm{C} / \mathrm{C}_{1}$ & $\mathrm{~L} / \mathrm{H}_{1}$ & $\mathrm{C} / \mathrm{C}_{1}$ & $\mathrm{~L} / \mathrm{H}_{1}$ & $\mathrm{C} / \mathrm{C}_{1}$ & $\mathrm{~L} / \mathrm{H}_{1}$ & $\mathrm{C} / \mathrm{C}_{1}$ & $\mathrm{~L} / \mathrm{H}_{1}$ \\
\hline 2.20 & 14.641 & \multirow{21}{*}{$\begin{array}{l}2.65 \\
2.60 \\
2.55 \\
2.50 \\
2.45 \\
2.40 \\
2.35 \\
2.30 \\
2.25 \\
2.20 \\
2.15 \\
2.10 \\
2.05 \\
2.00 \\
1.95 \\
1.90 \\
1.85 \\
1.80 \\
1.75 \\
1.70 \\
1.65 \\
1.60 \\
1.55 \\
1.50\end{array}$} & 64.883 & 1.45 & 5.167 & \multirow{21}{*}{$\begin{array}{l}1.90 \\
1.85 \\
1.80 \\
1.75 \\
1.70 \\
1.65 \\
1.60 \\
1.55 \\
1.50 \\
1.45 \\
1.40 \\
1.35 \\
1.30 \\
1.25\end{array}$} & \multirow{21}{*}{$\begin{array}{r}11.636 \\
10.783 \\
9.936 \\
9.095 \\
8.274 \\
7.498 \\
6.798 \\
6.186 \\
5.652 \\
5.176 \\
4.739 \\
4.326 \\
3.923 \\
3.751\end{array}$} \\
\hline 2.15 & 13.733 & & 46.117 & 1.40 & 4.736 & & \\
\hline 2.10 & 12.911 & & 35.514 & 1.35 & 4. 325 & & \\
\hline 2.05 & 12. 151 & & 29.117 & 1.30 & 3. 923 & & \\
\hline 2.00 & 11.437 & & 25.046 & 1.25 & 3. 521 & & \\
\hline 1.95 & 10.758 & & 22.215 & \multirow{2}{*}{\multicolumn{2}{|c|}{$\mathrm{H}_{2} / \mathrm{H}_{1}=5.00$}} & & \\
\hline $\begin{array}{l}1.90 \\
1.85\end{array}$ & $\begin{array}{r}10.104 \\
9.470\end{array}$ & & $\begin{array}{l}20.140 \\
18.513\end{array}$ & & & & \\
\hline 1.80 & 8.853 & & 17. 171 & 2.70 & 113.649 & & \\
\hline 1.75 & 8.252 & & 16.019 & 2.65 & 71.261 & & \\
\hline 1.70 & 7.668 & & 14.997 & 2.60 & 50.566 & & \\
\hline 1.65 & 7. 106 & & 14.068 & 2.55 & 38.884 & & \\
\hline 1.60 & 6.571 & & 13.205 & 2.50 & 31.849 & & \\
\hline 1.55 & 6. 067 & & 12.390 & 2.45 & 27.353 & & \\
\hline 1.50 & 5. 595 & & 11.609 & 2.40 & 24.266 & & \\
\hline 1.45 & 5.151 & & 10.852 & 2. 35 & 21.984 & & \\
\hline 1.40 & 4.729 & & 10.111 & 2. 30 & 20. 192 & & \\
\hline 1. 35 & 4. 322 & & 9.383 & 2.25 & 18.710 & & \\
\hline 1.30 & 3. 922 & & & & 17. 434 & & \\
\hline 1.25 & 3. 520 & & $\begin{array}{l}7.975 \\
7.312\end{array}$ & $\begin{array}{l}2.15 \\
2.10\end{array}$ & $\begin{array}{l}16.300 \\
15.265\end{array}$ & & \\
\hline \multicolumn{2}{|c|}{$\mathrm{H}_{2} / \mathrm{H}_{1}=4.50$} & & $\begin{array}{l}7.312 \\
6.697\end{array}$ & $\begin{array}{l}2.10 \\
2.05\end{array}$ & $\begin{array}{l}15.265 \\
14.300\end{array}$ & & \\
\hline 2.70 & 103.294 & & $\begin{array}{l}6.137 \\
5.631\end{array}$ & $\begin{array}{l}2.00 \\
1.95\end{array}$ & $\begin{array}{l}13.384 \\
12.500\end{array}$ & & \\
\hline
\end{tabular}

increases within the range of smaller values of $L / H_{1}$.

From now on the writer will continue his research on this problem by paying special attention to these points.

\section{Explanation of Figures and Tables of Section 6}

The dimensionless values of velocity $C / C_{1}$ and wave length $L / H_{1}$ for the various thickness ratio $H_{2} / H_{1}$. Computed values are based on the constants $(H, C, \rho)$ of the first layer.

$H_{k} \quad(k=1,2) \quad$ thickness of the layer in kilometers.

$C_{k} \quad(k=1,2,3)$ compressional wave velocity of the layer in $\mathrm{km} / \mathrm{sec}$.

$C_{k S S}(k=2,3) \quad$ shear-wave velocity of the layer in $\mathrm{km} / \mathrm{sec}$.

$\rho_{k} \quad(k=1,2,3)$ density of the layer in $\mathrm{gm} / \mathrm{cm}^{3}$.

$T \quad$ wave period in seconds.

$C \quad$ phase velocity in $\mathrm{km} / \mathrm{sec}$.

$U \quad$ group velocity in $\mathrm{km} / \mathrm{sec}$.

$L / H_{1} \quad L$ is wave length and $H_{1}$ is thickness of the 1st water layer.

For example: $H 21$ represents $H_{2} / H_{1}$ the ratio of thickness of secondary layer (sedimentary layer) to the first water layer. $V 21$ represents $C_{2} / C_{1}$, the ratio of compressional wave velocity. $V 3 S 1$ represents $C_{3 S} / C_{1}$, the ratio of shear wave velocity of the third solid medium to the compressional wave velocity of the first water layer. $R O 21$ represents $\rho_{2} / \rho_{1}$ the ratio of density. 


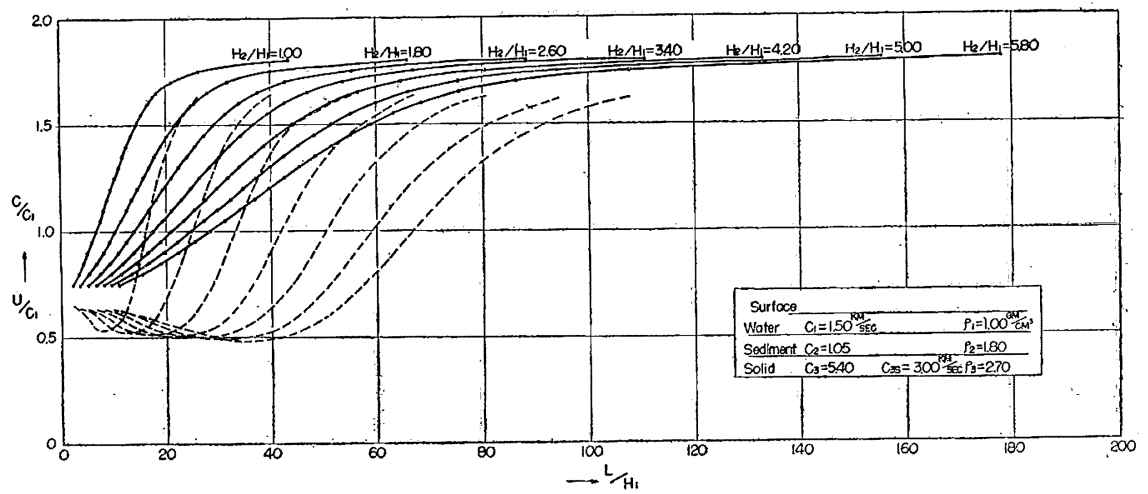

(a)

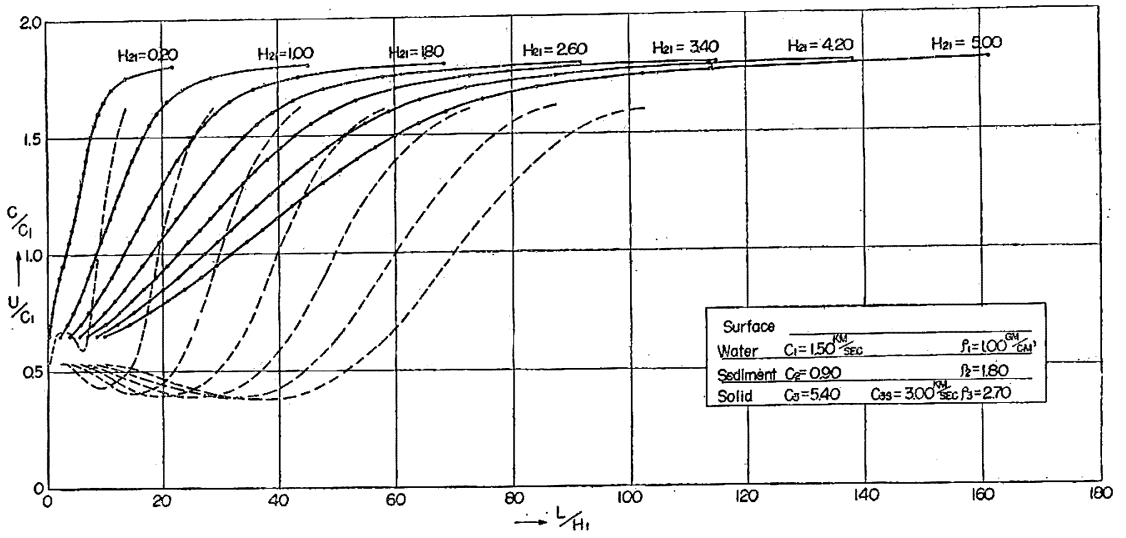

(b)

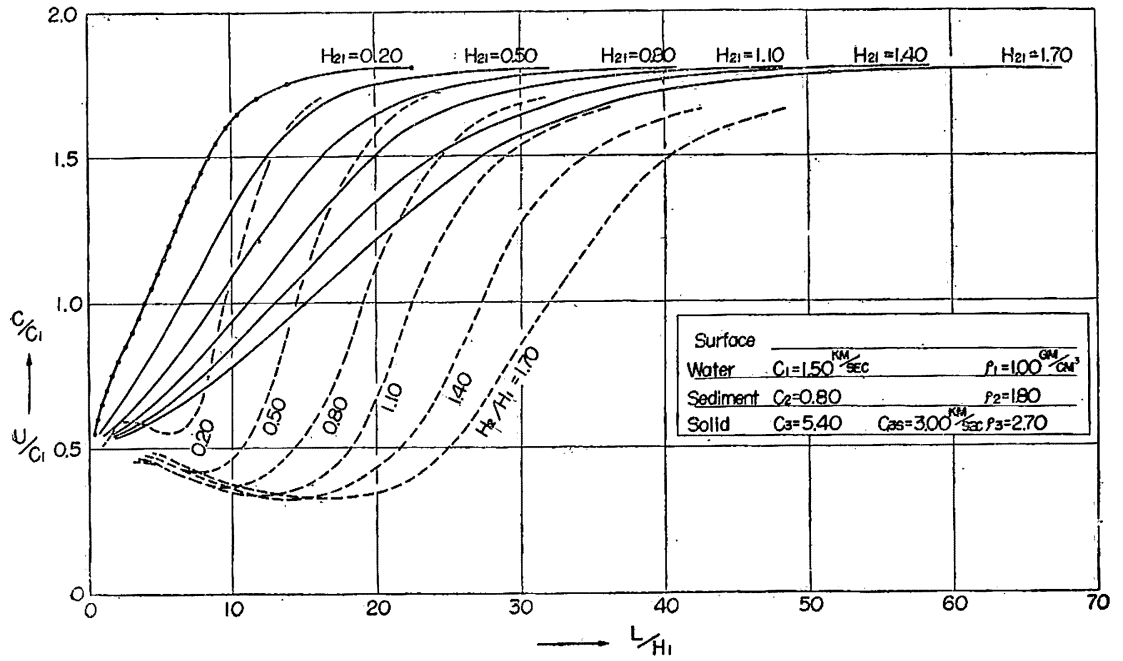

(c) 


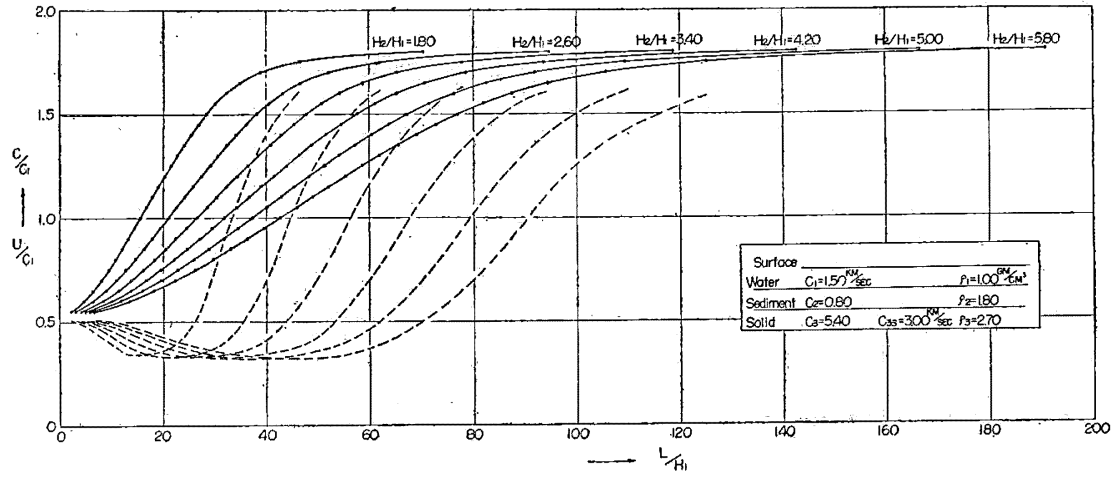

(d)

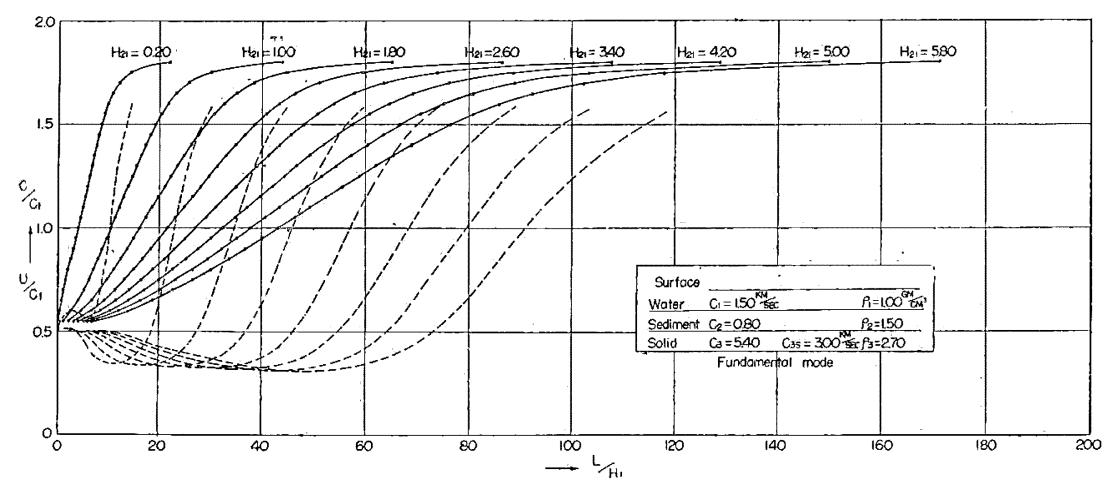

(e)

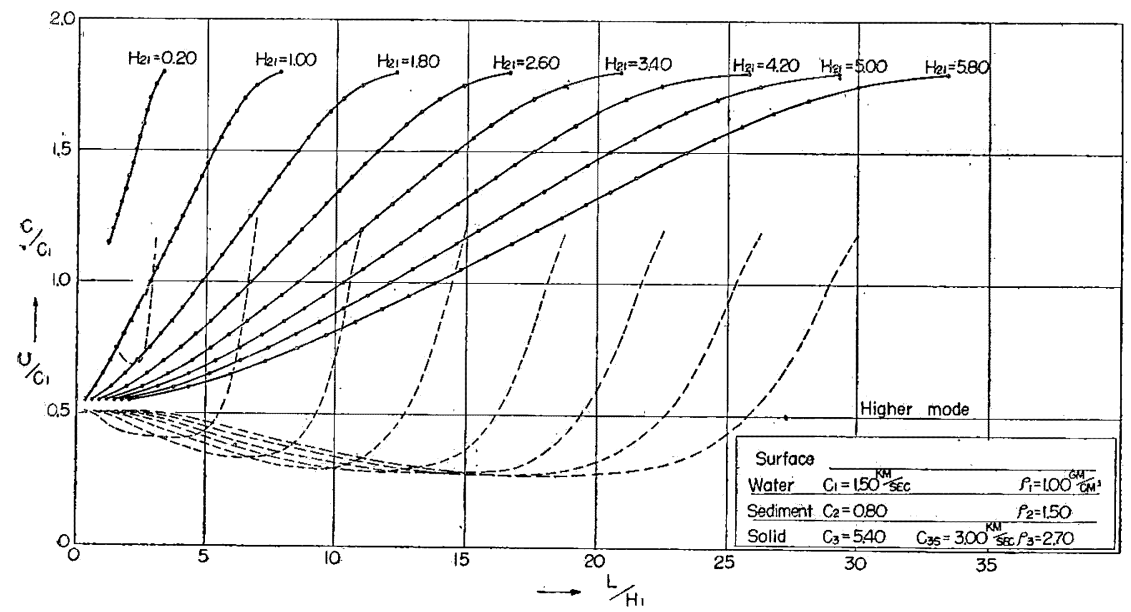

(f) 


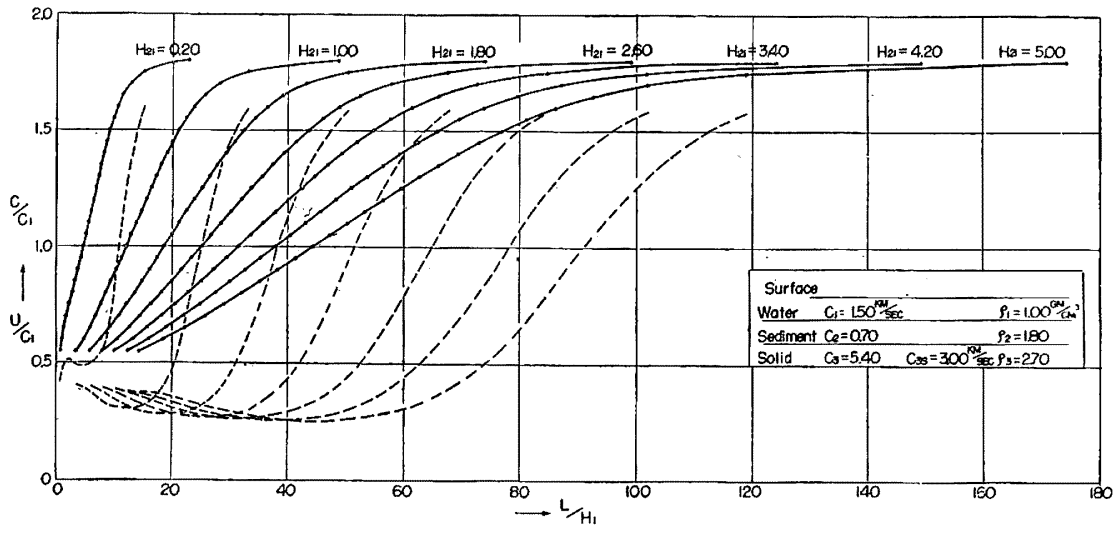

(g)

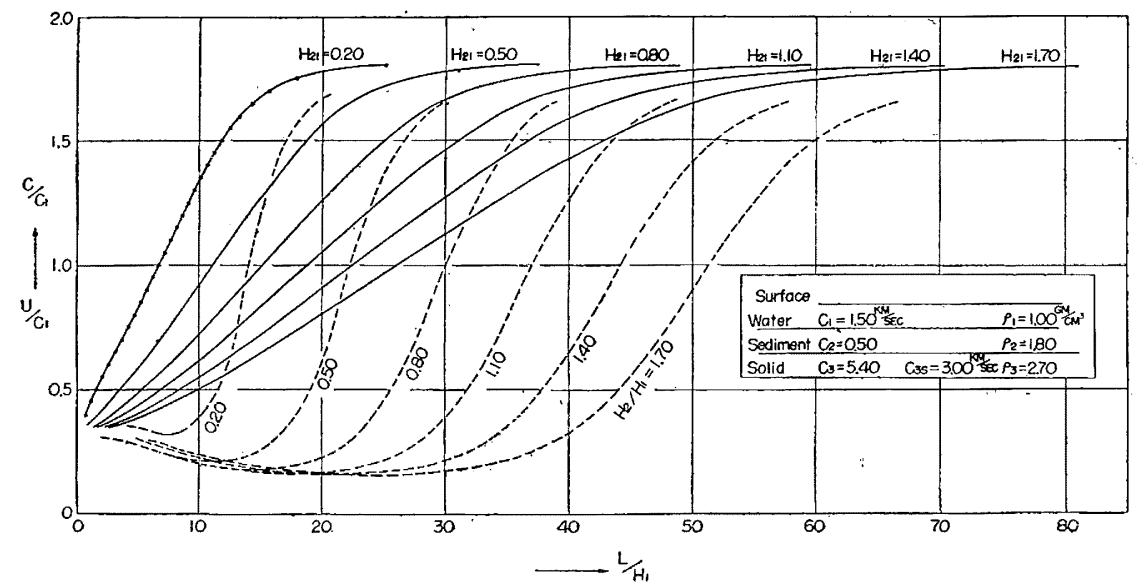

(h)

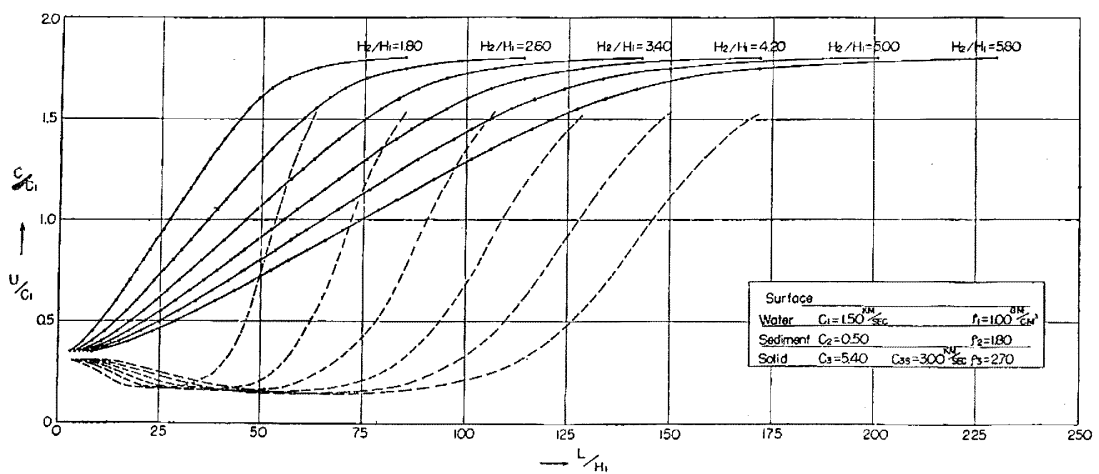

(i) 


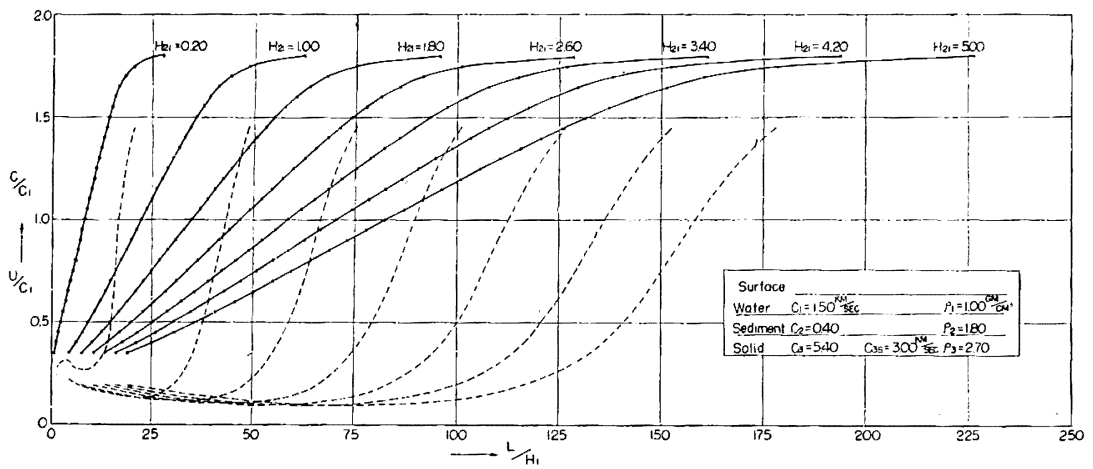

(j)

Fig. 37. Theoretical phase and group velocity of Rayleigh waves for the case of [liquid-liquid-solid] structure (see Tables 10,11, 12.) Group velocity was obtained by numerically differentiating the phase velocity.

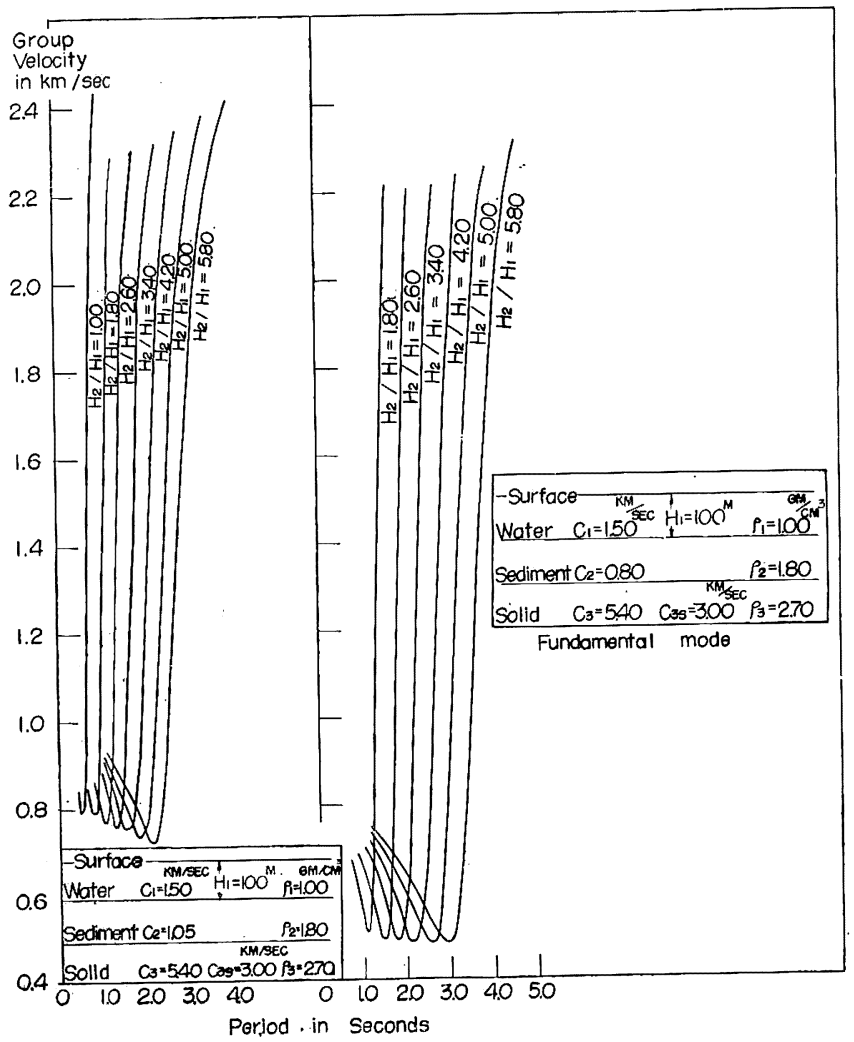

Fig. 38. Group velocity (U) against period (T) for the case of the model 37 (a) and (d). When $\mathrm{H}_{1}=100 \mathrm{~m}$.

\section{Nature of subma- rine earthquakes of crypto-volcanic activity off It $\hat{\imath}$ and the Kita-Izu earth- quake swarms}

From February to June, 1930, remarkable earthquake swarms occurred on the sea bottom off Itô. From November to December of the same year, the northern Izu district was shaken by a number of earthquakes. The writer studied the seismograms taken at Tomisaki $(A=67 \mathrm{~km})$, Tokyo $(\Delta=97 \mathrm{~km})$ and Yokohama $\quad(\Delta=68.5$ $\mathrm{km}$ ) with the aim of comparing the nature of these earthquakes with that of various 
other volcanic earthquakes.

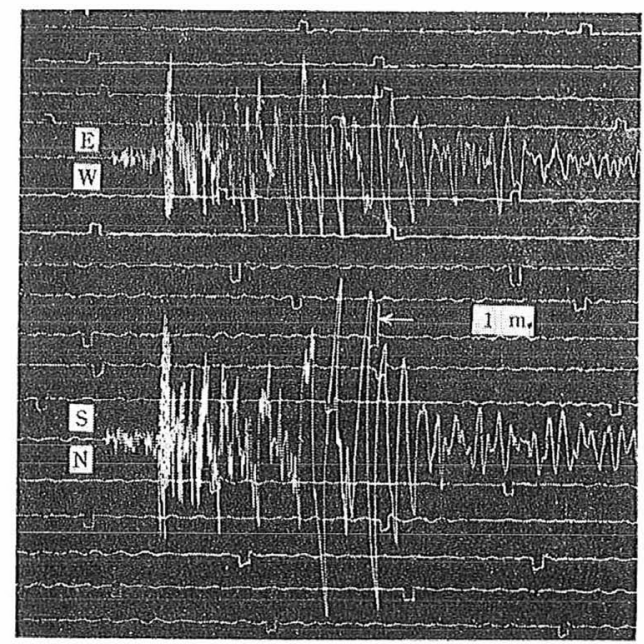

(a) Seismogram at Yokohama (L.M.O.) March $12,1930\left(12^{h} 46^{m} 32.2^{s}\right)$

Wiechert seismograph

Magnification: $V_{N}=79, \quad V_{E}=79$

Period: $T_{0 N}=5.7 \mathrm{sec}, \quad T_{0} E=5.7 \mathrm{sec}$.

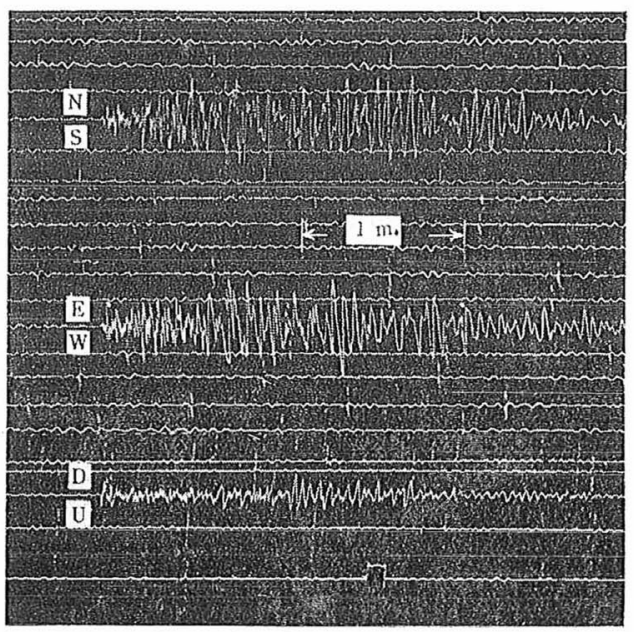

(b). Seismogram at Tokyo (J.M.A.) March 13, $1930\left(12^{h} 46 m 39.3^{s}\right)$

Wiechert seismograph

Magnification: $V_{N}=80, \quad V_{E}=80$

Period: $T_{0 N}=4.5 \mathrm{sec}, T_{0 E}=4.5 \mathrm{sec}$.

Fig. 39. Seismograms of the Itô crypto-volcanic activity observed at Yokohoma (L.M.O.) and Tokyo (J.M.A.).

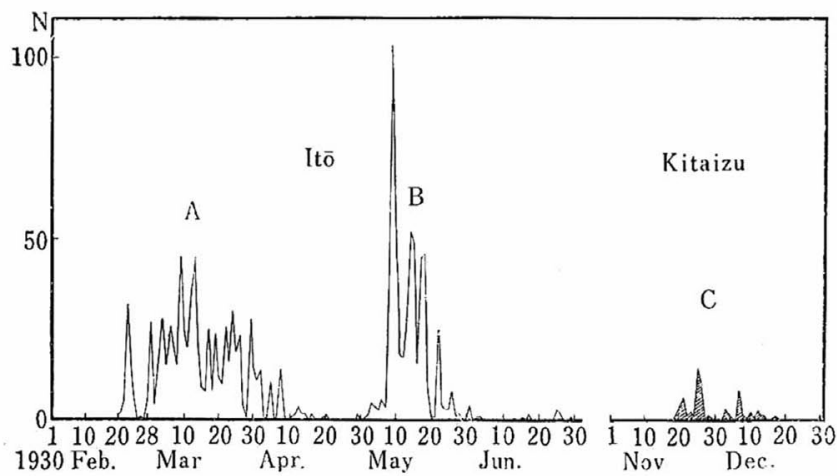

Fig. 40. Frequency-distribution of the Itô and Kita-Izu earthquakes in 1930 by "Kishō-yōran."
The time variations of the frequency of earthquakes are diagrammatized in Fig.40. As is known from the figure, the earthquakes can be classified into three groups by their number varying with the lapse of time. These groups were tentatively named $A, B$ and $C$. The earthquakes that occurred off Itô from February

19 to April 23 belong to $A$ group, those that occurred off Itô from April 24 to June 30 belong to $B$ group, and the earthquakes of northern Izu from November 8 to December 10 are $C$ group.

The relation between the amplitude $A$ and the frequency $n$ of the earthquakes can be expressed by the IsHimoto-IIDA formula,

$$
n(A) d A=k A^{-m} d A
$$

and when the formula is integrated by using 


$$
N(A)=\int_{A}^{\infty} n(A) d A
$$

Then the following formula is obtained:

$$
N(A)=\frac{k}{m-1} A^{-m+1} .
$$

On the basis of the formulas (1) and (2), the value of $m$ for each group of $A$, $B$ and $C$ becomes as shown in Tables 19 and 20 .

Table 19. Values of $m$ on amplitude-cumulative frequency relation

\begin{tabular}{|l|c|c|c|}
\hline Observatory & $\begin{array}{c}\text { A-group } \\
\text { Feb. 19-Apr. 23 }\end{array}$ & $\begin{array}{c}\text { B-group } \\
\text { Apr. 24-June 30 }\end{array}$ & $\begin{array}{c}\text { C-group } \\
\text { Nov. 8-Dec. 10 }\end{array}$ \\
\hline Tokyo & 1.79 & 1.76 & 1.50 \\
Tomisaki & 1.88 & 1.80 & - \\
Yokohama & 1.94 & 1.92 & 1.50 \\
\hline Average & 1.87 & 1.83 & \\
\hline
\end{tabular}

Table 20. Values of $m$ on amplitude-frequency relation

\begin{tabular}{|l|c|c|c|}
\hline Observatory & $\begin{array}{c}\text { A-group } \\
\text { Feb. 19-Apr. 23. }\end{array}$ & $\begin{array}{c}\text { B-group } \\
\text { Apr. 24-June 30 }\end{array}$ & $\begin{array}{c}\text { C-group } \\
\text { Nov. 8-Dec. 10 }\end{array}$ \\
\hline Tokyo & 1.33 & 1.06 & 0.88 \\
Tomisaki & 1.56 & 1.66 & - \\
Yokohama & - & - & - \\
\hline Average & 1.45 & 1.36 & 0.88 \\
\hline
\end{tabular}

The values are expressed by the graph of Figs. 41 and 42 .

The result revealed that the values obtained through the integral formula are larger by about 0.5. Little difference is recognized between $A$ group and $B$ group, and their values are nearly equivalent to the values obtained by many researchers from the A-type earthquakes of volcanic origin, whereas the values of $m$ of $C$ group are much smaller. This suggests, therefore, that the earthquakes of $C$ group may have a mechanism different from that of the other groups.

The values of the exponent $m$ so far known were $m=1.91$ of the earthquakes at Tesikaga, Hokkaido, obtained by Tosimatsu Matumoto through the cumulative frequency calculation (1959), and $m=1.7,1.8$ and 1.9 of the earthquakes at Tango, Nankai and Fukui, calculated by Ziro Suzuki. 


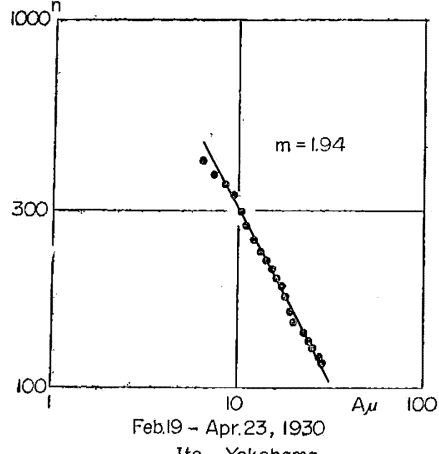

Ito - Yokohama

(a)

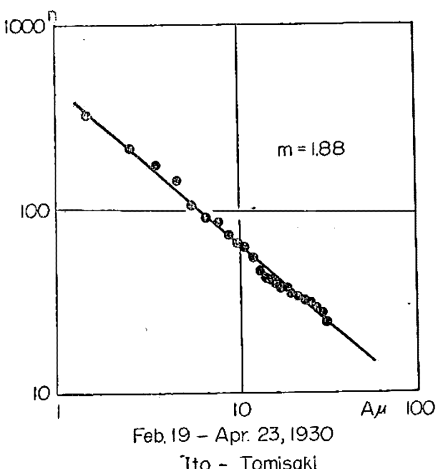

(c)

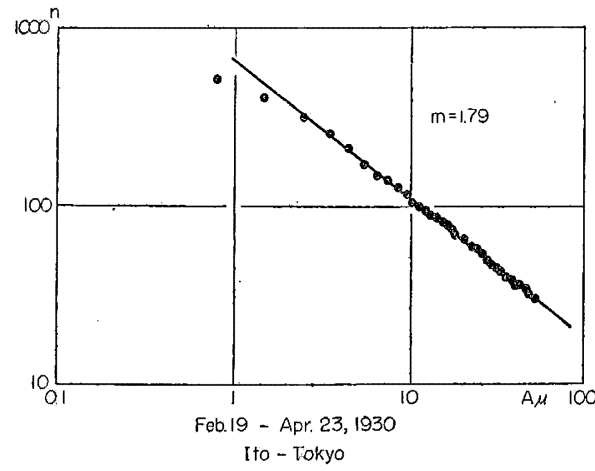

(b)

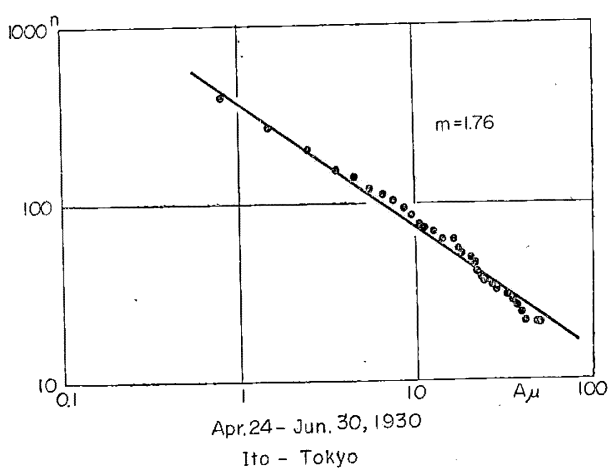

(d)

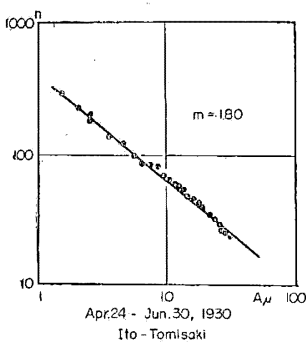

(e)

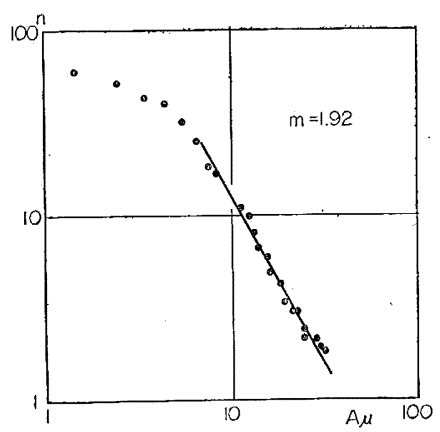

April 24 - June 30, 1930 Itö - Yokohiama

(f)

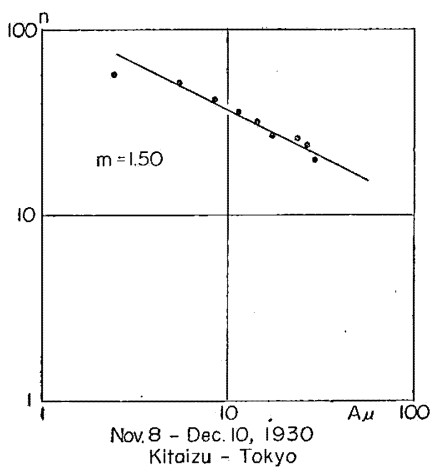

(g)

Fig. 41. Relation of amplitude-cumulative frequency of the Itô cryptovolcanic activity and Kita-Izu earthquake swarms (1930). 


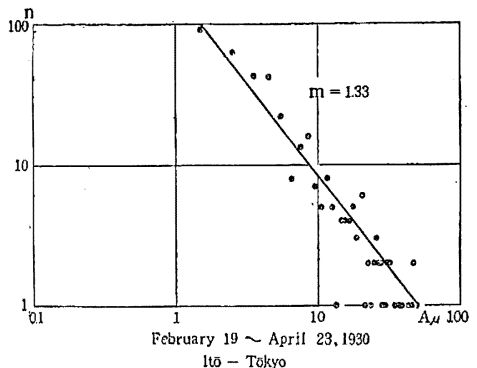

(a)

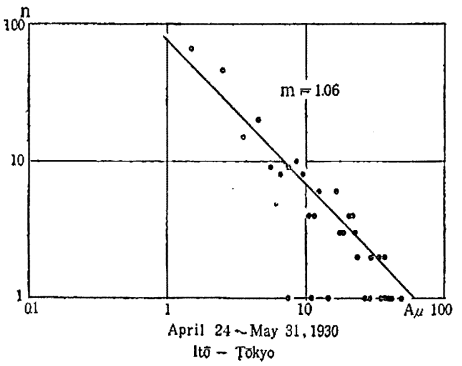

(c)

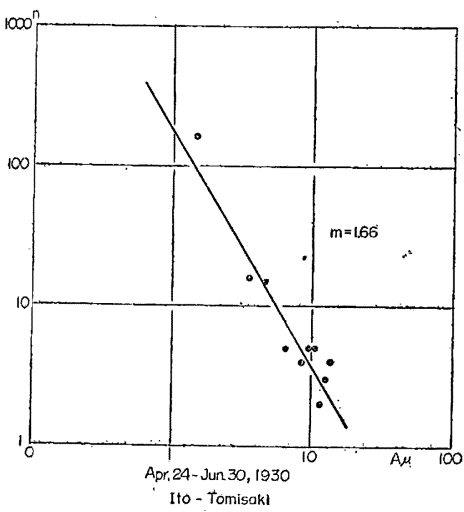

(d)

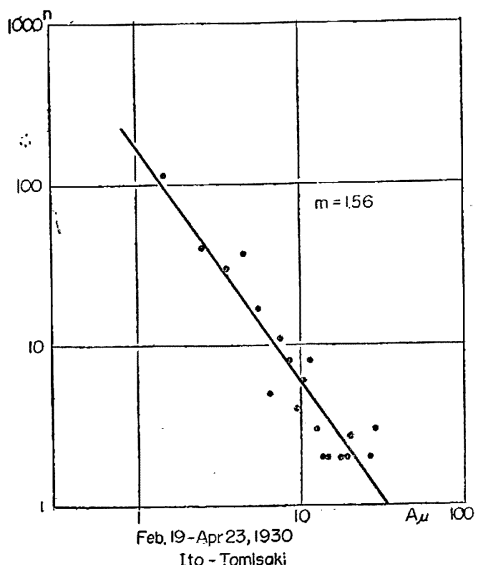

(b)

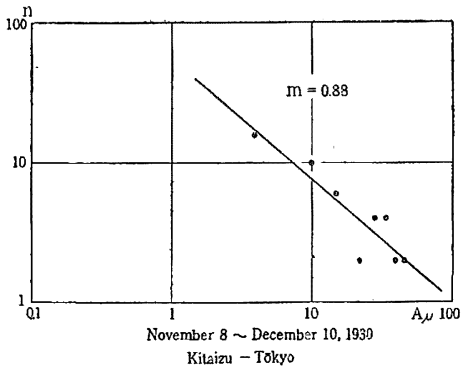

(e)

Figs. 42. Relation of amplitudefrequency of the Itô crypto-volcanic activity and Kita-Izu earthquake swarm (1930).

\section{Remarks}

The present paper deals with the principal results of the writer's study on the earthquakes in association with the volcanic activity of Volcano Usu (1943-1945). The writer's next plan is a study of the earthquakes related to the volcanic activity of Sakurajima, Hakone (1959-1960) and Itô (1930), from the same viewpoint as in the case of Usu. He intends to compare the result to be obtained with the known data of Usu (1943-1945), (1910), Rabaul (1942-1945), Aso (1946) and Oshima (19501951), to analyse the general characters and differences of each volcanic activity, to extract common features of volcanic activity, and to contribute something to the solution of the problem of prediction of eruption. 
Acknowledgements__ For the idea which supports the present study the writer is much indebted to Prof. Kenzô Sassa's valuable research on Volcano Aso. Suggestions from the late Dr. SAKuHeI FuJiwhara, the writer's respected teacher, were immeasurably helpful.

Without the asistance of Mr. Jun'ichi Ooura, Misses Etsuko Minemoto and U. IsHIBE this paper would not have been written. The writer's sincere gratitude is expressed to Mr. RINzo YAMAGUCHI for his cooperation in the discussion and calculation about the problems of section 6 and also to Prof. H. KAwASumi and Dr. Y. SATô for their guidance.

The writer's sincere gratitude is expressed to Doctors K. Wadati, H. HataKEYAMA, W.INOUYE and S. UNOKI for their guidance and encouragement.

Further the writer wishes to express his thanks to Dr. H. ITô, chief of the electronic computation center at the Japan Meteorological Agency, by whose courtesy the opportunity of using the IBM 704 electronic computer was given, and also to the other members of the office staff.

The writer is indebted to the meteorological offices at Sendai, Sapporo, Mori and Muroran for their kindness of lending him the seismograms, which helped the present research to an immeasurable extent.

It is a pleasure to record here a debt of gratitude to Professor Kenzô SAssa, Professor H. Honda, Messrs K. Musya, T. Matumoto, K. Wada, S. Takagi and K. NAITô for their encouragements and valuable advices in the course of the compilation of this paper.

\section{References}

Ewing, M. and F. Press, 1954: An investigation of mantle Rayleigh waves, Bull. Seism. Soc. Amer., 44, 127 147.

Gutenberk, B. and C. F. Richter, 1936: Gerl. Beitr., 47, 92.

Gutenderg, B. and C. F. Richter, 1956: Earthquake magnitude, intensity, energy, and acceleration (Second paper). Bull. Seism. Soc. Amer., 46, 105 145.

Ishimawa, T., 1950: New eruption of Usu volcano. Hokkaido, Japan during 1943 1945, Jour. Fac. Sci., Hokkaido Univ., Ser. 4, 7, 237 260.

JArdetzky, W.S. and Frank Press, 1953: Crustal structure and surface-wave dispersion, Part III, Bull. Seism. Soc. Amer., 43, 137.

Katsumata, M., 1955: Ground coefficient for amplitude of earthquakes; Quart. Jour. Seism., 19, Nos. $3-4,77 \sim 80$.

Kizawa, Tazashi, 1941: Investigation of the great earthquake in Chile of January 25, 1939, Quart. Jour. Seism., 11, 435 468.

KIZawa, TaKashi, 1951: Volcanic tremor and tilting of ground, Quart. Jour. Seism., 15, $18 \sim 34$.

Kizawa, Tazashi, 1951: Geophysical phenomena in relation to volcanic activity (I), Jour. Met. Res., 3, 249 260.

Kizawa, Taжashi, 1951: Geophysical phenomena in relation to volcanic activity (II), Jour. Met. Res., 3, 277 291 .

Kizawa, TAKashi, 1952: Geophysical phenomena accompanied by volcanic activities, Geophys. Mag., 23, 389 397.

Kizawa, Takashr, 1957: A study of earthquakes in relation to volcanic activity (I), Pap. Met. Geophys., 8, 150 169. 
Kizatwa, Taknshr, 1959: A study of earthquakes in relation to volcanic activity (II), Pap. Met. Geophys., 9, 204 239.

Kizawa, Taraser, 1960: Some new phases observed in a study of earthquake swarms relating to volcanic activity (I), Geophys. Mag., 29, 477 498 .

Krzatwa, TAXasim and Rinzo Yamaguti, 1960: Some new phases observed in a study of earthquake swarms relating to Volcanic Activity (II), Geophys. Mag., 30, 93 129.

Matumoto, T., 1959: Tesikaga earthquake of Jan. 31, 1959, Bull. Earthquake Res. Inst., 37, $531 \sim 544$.

Matuzata, T., 1928: "Observation of some of recent earthquakes and their time-distance curves", Bull. Earthquake Res. Inst., 5, 1 28.

Matuzata, T., 1959: On the crustal structure in North-East Japan by explosion seismic observations, Bull. Earthquake Res. Inst., 37, 123 154.

Mimatsu, M., 1949: Read at E.R.I. (June 1949).

Minakami, T., T. Ishris Awa and K., YAGT, 1951: The 1944 eruption of volcano Usu in Hokkaido, Japan Bull. Volcanologique, Ser. 2, Tome 11, 45 157.

Minatami, T., T. Mirazaikt and T. Takahashi, 1951: The 1950-1951 eruption of Oo-sima and its seismometrical investigations (I), Bull. Earthquake Res. Inst., 29, 359 381.

Moноrovičić, A., 1909: “Das Beben, Vom 8, X 1909” Zagreb., 9, 1 63.

Natramura, S., 1954: Seismology, 277.

Pereris, C.L., 1948: Theory of propagation of explosive sound in shallow water, Geol. Soc. Amer., Mem., 27, 1 116.

Peiceris, C.L. and I.M. Longrian, 1958: Ray theory solution of the problem of propogation of explosive sound in a layered liquid, Journ. Acoust. Soc. Amer., 30, 323 328.

Pereris, C.L., I.M. Longman and H. Lipson, 1959: Application of ray theory to the problem of long-range propagation of explosive sound in a layered liquid, B.S.S.A., 49, $247 \sim 250$.

Press, F., M. Ewing and I. Tolstor, 1950: The Airy phase of shallow-focus submarine earthquakes, B.S.S.A., 40, $111 \sim 148$.

Press, F., A.P. Crart, J. Oliver and S. Katz, 1951: Air-coupled flexural waves in floating ice, Trans. Amer. Geophys. Un., 32, 166 172.

Press F. and M. Ewinc, 1951 a: Theory of air-coupled flexural waves, Journ. Appl. Phys., 22, $892 \sim 899$.

Press, F. and M. Ewing, $1951 \mathrm{~b}$ : Ground roll coupling to atmospheric compressional waves, Geophysics, 16, 416-430.

SASSA K. 1935: Volcanic micro-tremors and eruption-earthquakes, Memoirs Colle. Sci. Kyoto Univ., 18, 255 293.

SASSA K., 1936: Micro-seismometric study on eruptions of the Volcano Aso. Memoirs Colle. Science, Kyoto Univ., 19, 11 56.

SASSA K., 1936: Anomalous deflection of seismic rays in Volcanic Districts, Memoirs Colle. Sci. Kyoto Univ., 19, 65 78.

Satô, Y. and Rinzo Yamaguchr, 1959: Velocity equation of the love waves propagated in multilayered media, Zisin (Jour. Seism. Soc. Japan.), 12, 61 67.

Suzurr, Z., 1955: A statistical study on the occurrence of small earthquakes, II, Sci. Rep. Tohoku Univ., Ser. 5, Geophy., 6, 2, 105-118.

TAKAHASHI R. and T., NAGATA, 1939: On the earthquake swarm which occurred in Oshima on June 18, 1938, Jour. Seism. Soc. Japan. 11, 161 167.

Tsubor, C., 1954: Determination of the Gutenberg-Richter's magnitude of earthquakes occurring in and near Japan, Jour. Seism. Soc., Japan, Ser. 2, 7, 185 193.

Tsubor, C., 1957: On the magnitudes of earthquakes, Jour. Seism. Soc. Japan, 10, 6〜23.

WADATI K., 1931: Shallow and deep earthquakes (3rd paper), Geophys. Mag., 4, 231 283.

WADATI, K., K. SAGISAKA and K. MASUdA, 1933: On the travel time of earthquake waves (Part I), Geophys. Mag., 7, 87 99. 


\title{
火山活動に関係する地震の研究（III）
}

\author{
木 沢綏
}

有珠火山の活動に伴って出現した一連の地震群 (Dec. 1943〜Oct. 1945) について 引続き研究して得 られた結果の主な概要をここに第 3 報として報告する

1. 櫴火活動に先駆する地震群 (A-type 地震) を調べた結果 昭和新山付近の distance coefficientの 值として $k=8.2 \mathrm{~km} / \mathrm{sec}$ 得た 同時に震源の深さは $10 \mathrm{~km}$ と求められて そしてとの深さは噴火に近 付くに従い次第に浅くなる事を示した

2. 表面波についての最大振巾の減衰式

$$
A=A_{0} \Delta^{-\frac{1}{2}} e^{-\alpha \Delta}
$$

に执いて 主な A-type 地震の観測值から $\alpha=5.8 \times 10^{-3} \mathrm{~km}^{-1}$ 及び $\alpha=5.6 \times 10^{-3} \mathrm{~km}^{-1}$ を得た 構造地 震の諸值 $(\alpha)$ と比較した

3. 先駆地震群の地震数 $N(t)$ と振巾 $A(t)$ が時閒と共にどら要化して莾火に近付くかを求めた 3 観测 所の值はいずれる一応

$$
N(t)=\mathrm{K}(t+c)^{-p}, \quad A(t)=\mathrm{K}^{\prime}\left(t+c^{\prime}\right)^{-p \prime}
$$

で現わされることを知つた 各常数をそれぞれ求めた

4. 森測候所 $(\Delta=54 \mathrm{~km})$ K記録された多くの A-type 地震波から S波の数秒後に眀瞭なその反射波 $S^{\prime}$ を見出し モホ層の深さ $H=25 \mathrm{~km}$ (平均値) を得た

5. 地震のエネルギー文ぴ 土地の隆起エネルギーを算出し 地震数 その他の現象との四連を考察し た

6. 森測候所の地震記象から 特別な新しい2つの相を見出した 伝播径路は海:である 伝播径路の地 教構造を [liquid-liquid-solid] Zび [liquid-solid-solid]の3 層構造とし 各層に常数をいろいろと与え て I. B. M. 704. 電子計算機により 各 case の Rayleigh wave の分散曲線を求めた第 2 層の Sedimentary layer が solid の場合 その Compressional wave の速度を第1層のそれよりる小さくとり thickness を適当にとる事によつて始めて問題の 2 つ相を説明する最も有望な結果が得られた

Sedimentary layer の存在と性質更にはとの大きな作用について強力な喑示を得た 桜島一鹿児島 (1939，1946年)でる 同じ性貿と思われる 2,3 の相を見出した

7. 1930年の Itō crypto-volcanic activity 文び同年の北伊豆地震群について石本-飯田の表現

$$
n d \mathrm{~A}=k A^{-m} d A
$$

に秋ける $m$ の值を求めた 有珠の地震群から得られた $m$ と比較した 